\title{
Libro Blanco para la Reforma del Gobierno Local
}

\author{
Ministerio de Administraciones Públicas \\ Secretaría de Estado de Cooperación Territorial
}

\section{PRÓlogo}

Con la elaboración de este Libro Blanco para la Reforma del Gobierno Local se ha querido, ante todo, poner en marcha un proceso de análisis y de debate que permitiese avanzar adecuadamente en el cumplimiento de nuestro compromiso de presentar un proyecto de Ley sobre el Gobierno y la Administración Local.

Para el Gobierno, es preciso que se haga un reconocimiento explícito de la naturaleza política de la autonomía local, así como proceder a las reformas necesarias para dotar a los gobiernos locales en España de más competencias y de más medios, en el marco de una articulación territorial del Estado sustentada en la lealtad institucional entre los tres niveles de gobierno, el central, el autonómico y el local.

El primer paso del procedimiento elegido para iniciar estas reformas ha sido la confección de este Libro Blanco, de manera que se incorporasen al proceso todos los actores implicados.

Hemos querido lograr, con ello, que los gobiernos locales sean sujeto, y no meramente objeto, del proceso de su reforma, sin menoscabo del hecho de que la última palabra en la materia, como es lógico en un Estado democrático, corresponda a las cámaras parlamentarias, a través, en su caso, de la aprobación de la ley que ultime el proceso.

El fin último de este amplio proceso de participación, realizado en colaboración con la Federación Española de Municipios y Provincias y las Federaciones de Municipios autonómicas, ha sido, por lo tanto, que la nueva Ley sobre el Gobierno y la Administración Local pueda ser el resultado del consenso entre los diferentes actores territoriales y entre las distintas fuerzas políticas. 
Todas las actividades desarrolladas en torno a este texto convierten al Libro Blanco en algo más que un diagnóstico sobre el gobierno y la administración local, porque el mismo procedimiento de deliberación pública que ha generado su contenido supone la apuesta por una forma distinta de legislar.

Entendemos que la manera de hacer las leyes resulta determinante en su posterior aplicación, por lo que hemos propiciado una reflexión conjunta sobre el régimen local, conscientes de que un asunto tan complejo como éste no puede ser abordado por el Gobierno en solitario.

Se ha querido contar, también, con la opinión del Consejo de Europa, pues es notoria la implicación de esta organización en materia de autonomía local y regional, y así tres de los mejores especialistas europeos en materia de gobierno local, con amplia experiencia en estudios comparados, han realizado un excelente informe que se ha incorporado a esta versión final.

El presente volumen recoge el resultado final de todo el proceso, articulado alrededor de tres líneas temáticas, que se refieren a las competencias, a la intermunicipalidad y al sistema de gobierno local.

El primer gran ámbito, el competencial, resulta esencial para poder establecer el grado de autonomía, y también el de responsabilidad, de la Administración Local, a partir de los principios básicos de subsidiariedad y proximidad.

Parece claro que la concreción de las competencias locales deba hacerse respetando el marco competencial de las Comunidades Autónomas, del mismo modo que parece una sugerencia positiva la formulada por la FEMP, en el sentido de que en las reformas de los estatutos de autonomía se tenga en cuenta, también, el ámbito competencial de las Administraciones Locales.

El segundo gran ámbito, el de la intermunicipalidad, está referido a las estructuras locales de segundo grado, absolutamente necesarias en el contexto de un mapa local altamente fragmentado como es el español.

En este sentido, la línea general indica que debe irse hacia el diseño de un modelo de intermunicipalidad que sirva para mantener en el nivel local las competencias locales, y que haga compatible el papel de la provincia con la competencia de las comunidades autónomas en materia de ordenación y organización de su territorio.

Respecto al tercer gran ámbito, el del sistema de gobierno local, las líneas principales apuntan a la necesidad de una diferenciación más clara entre las 
funciones del pleno y las del alcalde y los demás órganos que integren el ejecutivo local, así como a la conveniencia de incrementar el campo de acción de la potestad de autoorganización local, con un diseño no exhaustivo del modelo orgánico funcional que, manteniendo las garantías de democracia, control y participación, permita el respeto a la diversidad y la adaptación a las características locales.

Para ello, hay que plantearse la elaboración de un estatuto de los cargos electivos locales que permita el adecuado desarrollo de la función de oposición y de control del gobierno local, porque debemos asegurar que los gobiernos surgidos de las urnas tengan capacidad para gobernar, pero también que la oposición pueda ejercer el necesario control democrático.

La finalización de este Libro Blanco supone, por lo tanto, el inicio del proceso de redacción del proyecto de Ley sobre el Gobierno y la Administración Local, con el que pretendemos dotar, a partir de una voluntad de consenso, de nuevas reglas de juego a este gobierno que tanto influye en la vida de los ciudadanos, pues es el que éstos pueden identificar, con mayor claridad, como la parte del Estado más próxima a ellos.

Jordi Sevilla Segura

Ministro de Administraciones Públicas 


\section{PRESENTACIÓN}

\section{EL MARCO CONSTITUCIONAL}

UNA AUTONOMÍA LOCAL POLÍTICA EN EL MARCO DE LA CONSTITUCIÓN

\section{LA GARANTÍA CONSTITUCIONAL DE LA AUTONOMÍA LOCAL}

1.1 El núcleo constitucionalmente indisponible de la autonomía local. 1.2La protección constitucional frente a intromisiones en el ámbito de competencias legalmente asignado.

2. EL DESARROLLO NORMATIVO DEL RÉGIMEN LOCAL. LA FUNCIÓN DEL LEGISLADOR BÁSICO.

\section{LA DIMENSIÓN FINANGIERA DE LA AUTONOMÍA LOCAL}

3.1 La garantía constitucional de la suficiencia financiera

3.2La autonomía financiera local en la vertiente de los ingresos

3.3 La autonomía financiera local en la vertiente del gasto

II. EL MARCO EUROPEO DE LA REFORMA DEL GOBIERNO Y LA ADMINISTRACIÓN LOCAL EN ESPAÑA

UNOS GOBIERNOS LOCALES BASADOS EN EL ACERVO EUROPEO SOBRE LA AUTONOMÍA LOCAL

\section{DIAGNÓSTICO}

\section{PROPUESTAS}

\section{LAS COMPETENCIAS Y SERVICIOS LOCALES}

\section{ESTADO DE LA CUESTIÓN}

1.1 Ausencia de un listado de competencias locales y remisión al legislador sectorial

1.2Los servicios mínimos y las actividades o servicios esenciales.

1.3 La capacidad general de iniciativa y de prestación de servicios complementarios

1.4Ausencia de medios adecuados de defensa de las competencias 
1.5 Las limitaciones de la potestad normativa local

1.6 Ausencia del principio de suficiencia financiera

2. CRITERIOS QUE DEBEN ORIENTAR LA REGULACIÓN DEL SISTEMA DE COMPETENCIAS LOCALES

2.1 Principios básicos.
a) Autonomía
b) Naturaleza política del gobierno local
c) Subsidiariedad
d) Diversidad, flexibilidad y supletoriedad
e) Principio de proporcionalidad
f) Cláusula general de competencias
g) Garantías de suficiencia financiera para el ejercicio de las competencias.

2.2 Las potestades y las competencias locales

2.3 Las competencias locales se definen en base a potestades públicas.

2.4 Materias en que deben atribuirse competencias a los municipios y determinación de los ámbitos de interés local

\section{PROPUESTAS}

\section{LAS ESTRUCTURAS TERRITORIALES DE GOBIERNO LOCAL}

\section{DIAGNÓSTICO}

1.1 El sistema local español

1.2 La intermunicipalidad en España

\section{LA PROVINCIA}

2.1 Situación actual

2.2 El Nuevo papel de la Provincia como Entidad Local

A) La Cooperación Local como funciones esencial de las Diputaciones

B) Otras competencias

C) La relación de las Diputaciones con los Ayuntamientos. El trabajo en red y la concertación

\section{PROPUESTAS}


V. EL SISTEMA DE GOBIERNO LOCAL

PROPUESTAS

VI. GESTIÓN DE SERVICIOS PÚBLICOS Y BIENES

1. La gestión de los servicios públicos locales

PROPUESTAS

2. LOS BIENES DE LAS ENTIDADES LOCALES

PROPUESTAS

VII. LAS RELACIONES INTERGUBERNAMENTALES.

UN AMPLIO DESARROLLO DE LOS PRINCIPIOS DE COOPERACIÓN Y COOR DINACIÓN INTERGUBERNAMENTALES

PROPUESTAS

VIII. LA COOPERACIÓN LOCAL EN EL ÁMBITO INTERNACIONAL 


\section{PRESENTACIÓN}

Hace veinticinco años las necesidades de los municipios españoles eran evidentes.

Bastaba pasear por cualquier pueblo para comprobar el estado de postración de equipamientos y servicios locales. Hasta entonces, la administración local había sido un apéndice de la administración estatal, una mera terminal periférica cuya expresión más palmaria era el nombramiento, según la población del municipio, del alcalde por el gobernador civil o por el ministro de la gobernación.

En 1979 la agenda local estaba clara. Desde finales de 1975, los municipios se habían instalado en una situación de incertidumbre ante la perspectiva de cambio que agravó aún más su marginación institucional: nadie quería cerrar el último ayuntamiento franquista. Así a cuarenta años de subordinación política, se sumaba casi un quinquenio de retraso.

Cuando fueron elegidos los primeros alcaldes y concejales se entregaron con entusiasmo a recuperar el tiempo perdido. En pocos años, pueblos y ciudades cambiaron de imagen: casas de la cultura, instalaciones deportivas, alumbrado, pavimentación, saneamientos, agua potable proporcionaron a los vecinos bienestar y oportunidades vitales.

Hemos conmemorado un cuarto de siglo con ayuntamientos democráticos rindiendo un merecido homenaje a quienes decidieron dar un paso más, a las mujeres y hombres que saltaron del altruismo cívico al compromiso político y presentaron su candidatura para dirigir sus municipios. Fueron ellas y ellos los protagonistas de un esfuerzo político que inauguró una tradición democrática municipal que nos permite hoy mirar el pasado con ojos de futuro. Como el clásico, podemos decir que el municipalismo español está cargado de pasado y grávido de porvenir.

Cualquier demócrata tiene una deuda de gratitud con aquella generación: entregaron un testigo que luego se ha ido acrisolando hasta ofrecer en nuestros días un valioso legado que nosotros tenemos el deber y la obligación de conservar y acrecentar.

Las necesidades de nuestros municipios ya no son evidentes. Sin bajar la guardia, sin caer en la complacencia, podemos afirmar que las necesidades más elementales están razonablemente cubiertas. El reto hoy es otro, mucho 
menos visible pero no menos apremiante. Por acudir a un ejemplo, los polideportivos y las casas de la cultura deben favorecer la convivencia de gentes venidas de todo el mundo a nuestros pueblos y ciudades, deben ser el lugar de aprendizaje y tolerancia para vivir con la diversidad de creencias y opiniones que aseguran la armonía entre unidad y pluralidad.

De forma inadvertida pero perseverante, los ayuntamientos han contribuido decisivamente a promover el diálogo entre culturas, y sin embargo la competencia sobre inmigración no figura en el elenco de materias señaladas en la Ley de Bases de Régimen Local. Ya no se trata únicamente de construir equipamientos deportivos o de prestar servicios, el desafío ahora es que el deporte sea un medio para educar a una ciudadanía en valores cívicos o que los servicios públicos sean el reclamo de una residencia de calidad o el señuelo que atraiga inversiones no especulativas al territorio.

Los ayuntamientos han dejado de ser organizaciones de rendimiento que actúan en un entorno simple y previsible, y han pasado a ser organizaciones estratégicas que han de dar respuesta a los efectos más inquietantes de la globalización, neutralizando sus amenazas y aprovechando las oportunidades que abre.

Queda lejos la lectura de la autonomía local como autonomía administrativa vinculada a la gestión de unos intereses privativos del municipio. La autonomía local es autonomía política, con capacidad para ordenar y gestionar bajo la propia responsabilidad una parte sustancial de los asuntos públicos mediante el impulso de políticas propias. Así lo señala la Carta Europea de Autonomía Local en una rotunda declaración que enlaza con el discurso sobre la gobernanza. Por su flexibilidad, por su adaptación a las peculiaridades del territorio, el municipio se halla en la mejor disposición para dar respuestas locales a problemas globales. Los ayuntamientos han experimentado en carne propia la rivalidad suicida de ofrecer suelo gratuito, exención de impuestos y mano de obra barata, han comprobado dramáticamente que esta subasta negativa solo atrae capital especulativo que no tarda en emigrar a otros territorios donde las condiciones son más favorables.

Los gobiernos locales tienen plena conciencia de que no basta la tradicional ventaja comparativa del comercio internacional, lo que ubica a un territorio en el mapa de la globalización no es la posesión de un recurso escaso ni una situación geoestratégica de privilegio, lo que verdaderamente evita la globalización por la puerta trasera es la ventaja cooperativa, el liderazgo político del gobierno local para que actores públicos y privados cobren sentido de sus interdependencias y formen una red capaz de hacer competitivo el terri- 
torio. Es la calidad de las interacciones entre actores el mayor activo institucional del que una ciudad puede disponer. Por tanto, el civismo de la población, la seguridad jurídica, la calidad de los servicios y el capital social se vuelven variables claves.

Ahora bien ninguna de estas condiciones surge espontáneamente, deben ser promovidas por el gobierno en un ejercicio de impulso político que exige justamente que organizaciones formalmente autónomas se conviertan en funcionalmente interdependientes.

Esta es una realidad que comienza a ser habitual en muchos municipios españoles que han desarrollado experiencias de planificación estratégica, constando que muchas de las competencias que necesitaban activar se hallaban en otros niveles de gobierno con menor información y más recursos económicos. Esta frustración les ha llevado a reivindicar más competencias y más financiación. Es esta situación insatisfactoria la que motiva la redacción de este Libro Blanco para la Reforma del Gobierno Local en España.

El Libro Blanco quiere hacer un análisis detenido de la situación del gobierno local alrededor de tres grandes ejes. En primer lugar las competencias, en segundo los niveles intermedios de gobierno y por último, la organización y funcionamiento.

Entre estos tres apartados hay una relación que pudiera enunciarse en los términos siguientes: la variable clave son las competencias. La fijación de las competencias municipales permitirá evaluar su coste, precisar las funciones de los niveles intermedios y articular la organización y funcionamiento de los municipios para que puedan desempeñar con garantías las competencias que reciban.

A modo de prólogo se adelantan algunas ideas sobre estos tres temas claves con la intención de preparar la lectura más pormenorizada que se hace en el Libro, así como sobre los otros contenidos esenciales del Libro Blanco.

I

La Carta Europea de Autonomía Local señala en su artículo 3.1:

Por autonomía local se entiende al derecho y la capacidad efectiva de las entidades locales de ordenar y gestionar una parte importante de los asuntos públicos, en el marco de la Ley, bajo su propia responsabilidad y en beneficio de sus habitantes. 
Y en el artículo 4.4 Las competencias encomendadas a las entidades locales de ben ser normalmente plenas y completas. No pueden ser puestas en tela de juicio ni limitadas por otra autoridad central o regional, más que dentro del ámbito de la Ley.

Ambos artículos configuran una visión de la autonomía local alejada de la manera tradicional que la caracteriza como un núcleo indisponible frente al legislador sectorial.

La define en positivo no tanto para limitar cuanto para delimitar. La Carta Europea prescribe que no se trata de preservar una institución protegiéndola sino de dar contenido a un poder político legitimado democráticamente. Por tanto, el municipio no tiene derechos frente al Estado o las comunidades autónomas sino competencias compartidas con el Estado y las comunidades autónomas.

Es decir, el municipio es el tercer pilar sobre el que se asienta la articulación territorial del Estado. Como hemos examinado, esta posición constitucional sólo es viable si los municipios, además de derecho a intervenir en todos los asuntos que afecten a la comunidad local, cuentan con un ámbito competencial propio. La lista de competencias es imprescindible para actuar ante eventuales conflictos de competencia entre los municipios y la comunidad autónoma o entre los municipios y el Estado.

Hasta ahora el municipalismo ha sido un convidado de piedra y el pagano de los conflictos de competencia entre el Estado y las comunidades autónomas. Esta tercería pasiva ha propiciado una situación anómala: la naturaleza bifronte del régimen local ha dado la imagen de que el Estado defendía la autonomía local frente a las comunidades autónomas cuando la realidad era bastante más compleja porque la autonomía local ha sido menoscabada tanto por el Estado como por las comunidades autónomas.

$\mathrm{Al}$ renunciar la Ley de Bases a fijar competencias propias y no disponer el gobierno local de un mecanismo de defensa de la autonomía local, los municipios han carecido de referencias normativas mínimamente perfiladas para impugnar el vaciamiento de unas competencias a las que solo tienen derecho nominal y cuyo alcance, en última instancia, su alcance depende de la voluntad más o menos favorable del Estado o de las comunidades autónomas, una graduación difícilmente controlable por los tribunales ya que se trata de una decisión política imposible de fiscalizar con parámetros jurídicos. 
Expresado en otros términos: no es lo mismo impugnar una norma por los excesos que comete o por los derechos de los que priva que por sus lagunas o derechos que deja de atribuir. La ausencia de competencias propias deja a los municipios a merced de la legislación sectorial estatal con la sola salvaguarda de la obligación por parte del Estado y de las comunidades autónomas de reservarles un espacio indeterminado. A nadie se le oculta la vulnerabilidad de esta previsión en un Estado habituado al centralismo y en unas comunidades autónomas en plena fase de afirmación institucional.

Tanto la Ley de Bases como los Estatutos son leyes interpuestas que no pueden oscurecer que la autonomía local es autonomía política en el marco de la Constitución y no mera autonomía administrativa en el marco de la ley. La garantía del sistema de gobierno local se encuentra en la Constitución y no en el legislador, sea estatal o autonómico.

La expresión más clara de la posición constitucional del gobierno local es que la cláusula general de competencia municipal tendría anclaje directo en la Constitución y la ordenanza municipal no sería un reglamento cualquiera sino una norma sustantiva que articula jurídicamente una decisión política de tal forma que si el Estado o la comunidad autónoma pormenorizaran reglamentariamente la regulación de una materia de la competencia local, tendría carácter supletorio frente a la aplicación prevalente de la ordenanza.

De la misma forma que un concepto extensivo de legislación básica vacía de contenido la competencia de una comunidad autónoma, también una legislación exhaustiva autonómica suprime la autonomía local allí donde el municipio tenga reconocidas competencias.

Una vez delimitado el contenido competencial de la autonomía local, será factible establecer unas relaciones interadministrativas donde el derecho a intervenir no sea una declaración desmentida por el simple expediente de conceder a los municipios la posibilidad de ser escuchados en comisiones constituidas para la participación en la regulación de una materia.

Esta ha sido una práctica habitual. La falta de competencias propias se ha compensado, pretendidamente, con fórmulas de participación en órganos y procedimientos estatales y autonómicos sin más alcance que el proponer o informar. Lo más grave de esta supuesta compensación es que, en realidad, ha provocado aún más el desdibujamiento del concepto de competencia propia porque el derecho a participar ha liberado a Estado y comunidades autónomas de atribuir competencias. 
A poco que se reflexione, este juego de entender garantizada la autonomía local con el derecho a participar ante la imposibilidad de fijar competencias, provoca un círculo vicioso: sin una identidad definida previa no se puede intervenir, para que la cooperación o la coordinación de competencias no signifique una pérdida de autonomía, es necesario que quienes cooperen o se sujeten a coordinación acudan al proceso con una actitud abierta pero también con una posición que refleje un ámbito de poder propio.

De lo contrario, la coordinación acaba siendo una imposición velada más parecida a la imposición que a la paridad institucional que exige la relación entre niveles de gobierno autónomos. El Tribunal Constitucional ha fijado que la coordinación presupone la inalterabilidad de la competencia, obviamente para que algo resulte no alterado debe, con carácter previo, disponer de un contorno preciso.

Este dato falta en el ámbito local. La efectividad de las competencias municipales depende justamente de la voluntad del Estado y de las comunidades autónomas.

Quienes deben garantizar la autonomía local pueden, también, socavarla.

Esta petición de principio otorga al Estado y a las comunidades un control que, si bien no se ejercita frente a actuaciones administrativas concretas por prohibir la LRBL los controles de oportunidad, tiene lugar en la fase de delimitación competencial prevista en la correspondiente legislación sectorial.

Nos encontramos ante un auténtico control ex ante probablemente como reacción preventiva ante la atribución de competencias que privaría de los controles de la delegación. Cuando esto ocurre, la coordinación pierde su sentido de visión de conjunto y pasa a ser un título material de tal forma que la intervención o participación en órganos mixtos se vuelve un simple derecho de audiencia.

Algún paso se dio en 1999 cuando el artículo 58.2 de la LRBRL intentó garantizar la participación del municipio afectado en los procedimientos de determinación de usos y en la adopción de resoluciones por parte de otras administraciones públicas en materia de concesiones o autorizaciones relativas al dominio público de su competencia. La garantía consiste en el carácter preceptivo del informe municipal.

Sin embargo, como un acto reflejo, condiciona la garantía a que la legislación sectorial la contemple, enunciando así a conceder a la legislación bási- 
ca un necesario contenido sustantivo que asegure mayor relevancia a la participación municipal, al tiempo que pierde la oportunidad de cumplir un papel clave en la regulación del régimen local diferenciando con claridad su naturaleza frente a las leyes sectoriales.

Retomando la idea inicial, no puede fiarse al criterio de oportunidad del legislador el ámbito reservado al gobierno local, no es una cuestión de límites (en este caso de autolimitación) sino de delimitación coherente con los principios constitucionales que rigen la distribución territorial del poder político y administrativo.

Tal vez, por esta razón, no convenga aludir a la interpretación debilitada o modulación del principio de reserva de ley cuando de potestad normativa municipal se trate.

Sencillamente nos hallamos ante la necesidad de delimitar competencias entre dos niveles de gobierno -estatal y autonómico, por una parte, y local, por otro- legitimados democráticamente.

La concepción extensiva de la reserva de ley degradaría la autonomía local a mera ejecución discrecional de la ley ignorando su naturaleza política y el derecho del gobierno local a disponer, bajo la propia responsabilidad, de una parte importante de los asuntos públicos decidiendo entre varias opciones políticas.

La consecuencia más importante de este planteamiento político sería que las ordenanzas municipales no requieren una habilitación positiva por parte de la ley siempre que no haya reserva de ley y, por tanto, la falta de concreción de una ley sectorial en la regulación de una materia no deber ser interpretada como inexistencia de competencia local.

Hay pues, un derecho a la espontaneidad del gobierno local para dar respuesta a las demandas ciudadanas innovando el ordenamiento jurídico, una presunción de competencia universal derivada de la garantía constitucional de la autonomía local. Así lo ha reconocido la jurisprudencia del Tribunal Supremo que en la Sentencia de 30 de abril de 1999 calificó de competencias propias las enumeradas en los artículos 25 y 26.

La propuesta de este Libro Blanco es fundir ambos artículos en una lista actualizada de competencias mínimas, en un marco legal adecuado recogiendo una práctica ya acrisolada. 
$\mathrm{Al}$ enumerar las competencias locales en una lista se pretende elevar la Ley de Bases de Régimen Local para hacer efectiva la función constitucional del legislador local y su integración, junto a los Estatutos de Autonomía, en el bloque de la constitucionalidad local.

\section{II}

Si tenemos en cuenta la realidad del municipalismo español integrado por una mayoría de municipios menores de cinco mil habitantes parece lógico concluir que la reflexión en torno a las competencias, sólo tiene sentido cuando se refiere a medianas y grandes ciudades. Para la mayoría de municipios, las competencias propias solo son viables si contamos con niveles intermedios consistentes capaces de contribuir a que las competencias municipales se ejerzan con economías de escala.

Fue inevitable que el Tribunal Constitucional elaborara la teoría de la garantía institucional dirimiendo un conflicto de competencias entre una comunidad autónoma y una provincia. Las comunidades autónomas buscaron su identidad institucional en pugna con el Estado y el mundo local. Como poderes recién alumbrados, hacerse un hueco entre los dos poderes y encontraron en la provincia un objetivo propicio.

$\mathrm{Al}$ estar recogida la autonomía provincial en la Constitución, el Tribunal se vio obligado a argumentar un concepto de autonomía local en abstracto que resultaba poco indicativo al tomar como referencia las competencias de las diputaciones. Dijimos antes que los municipios han sido unos espectadores impotentes en la definición de la autonomía local ya que los conflictos de competencia se han ventilado entre el Estado y las comunidades autónomas.

Esta "ajeneidad" se ha agravado porque se ha sustantivado en la jurisprudencia constitucional una autonomía provincial desvinculada de su condición de agrupación de municipios. Está claro que la configuración de la autonomía provincial ha de experimentar profundas transformaciones en el Estado de las autonomías.

Provincias y municipios, ayuntamientos y diputaciones integran una misma comunidad política local, comparten un mismo interés político, entre diputación y ayuntamientos no media una relación jerárquica sino una relación de paridad institucional. Esto no significa que interés provincial e interés municipal converjan espontáneamente, es necesario ajustar ambas realidades en 
un proceso de concertación que intenta conciliar los conceptos de coordinación y cooperación.

Como ha señalado el Tribunal Constitucional, la coordinación se ejerce desde una cierta supremacía institucional mientras que la cooperación implica la voluntariedad y la equiparación de las instituciones que deciden colaborar en la consecución de un objetivo que aisladamente no podrían alcanzar.

La naturaleza de la provincia como agrupación de municipios permite que la coordinación no derive de una posición de supremacía sino de la visión de conjunto que proporciona el conocimiento de las diferentes políticas municipales. A diferencia de una comunidad autónoma, una diputación no responde a una carencia o una iniciativa municipal con una mera transferencia de recursos que, una vez concedida, se desentiende de su evolución y destino final. La singularidad institucional de la diputación pasa, precisamente, por la interacción constante diputación-ayuntamiento en todo el proceso de ejecución y evaluación del proyecto.

En otras palabras: la diputación no es una financiadora de municipios a través de subvenciones sino una colaboradora que aporta a las competencias municipales, solvencia técnica, intercambio de información y economías de escala.

La ubicación correcta de las diputaciones en el Estado de las autonomías es la de un gobierno instrumental con competencias funcionales y legitimación indirecta. Si una diputación reparte con una mano el dinero que recibe en la otra sin añadir valor pierde su sentido, haciendo buena la máxima de go bierno intermediario, gobierno innecesario.

En cambio, si la diputación aumenta las interdependencias municipales favoreciendo la conciencia de un interés compartido, contribuirá a fijar en el ámbito local un poder político que, de otra forma, inevitablemente, saltaría a la comunidad autónoma.

El deslizamiento de lo local a lo autonómico es permanente porque la escasa capacidad de buen número de municipios lleva fácilmente a invocar interés supramunicipal en la regulación de una materia. Hay que defender, sin embargo, que lo que excede de un municipio no es autonómico sino que, en muchas ocasiones, es supramunicipal. Quizás fuera conveniente reivindicar no tanto la supramunicipalidad como la intermunicipalidad, la facultad de los municipios para asociarse en la prestación de servicios o para dar impulso a un proyecto conjunto. 
El tipo ideal de diputación sería aquel en el que fomenta la intermunicipalidad y establece relaciones de complementariedad con mancomunidades y otras formas de asociacionismo municipal. Obviamente este modelo de diputación exige cambios importantes en su funcionamiento.

En primer lugar hay que plantear si el partido judicial es la referencia adecuada para designar diputados, en segundo lugar, habría que asegurar la participación efectiva de los municipios en las políticas impulsadas por la diputación. Hasta ahora no había más garantías que la genérica alusión de la Ley a la intervención de los municipios en la elaboración de los Planes Provinciales de Obras y Servicios, tal vez la obligación de abrir un Registro de Prioridades Municipales fuera una buena vía. En tercer lugar, resulta imprescindible establecer cauces adecuados para la rendición de cuentas exponiendo con transparencia las políticas de la diputación en cada municipio. Quizás un Registro de Actuaciones pudiera cumplir esta finalidad.

Mención específica merece el personal de las diputaciones. Hasta ahora el rasgo distintivo de las diputaciones han sido los planes provinciales vinculados a los servicios mínimos que los municipios debían prestar obligatoriamente. La Encuesta de Infraestructuras y Equipamientos Locales ha prestado un apoyo fundamental en la asignación objetiva de fondos. Ahora bien, las necesidades más evidentes de los municipios están razonablemente cubiertas y ahora sus retos se mueven en políticas más integrales, basta reparar en las competencias reivindicadas por los municipios, para comprobar que las diputaciones deben estar a la altura de esta nueva agenda local.

La elaboración del Plan y la metodología de la Encuesta constituyen un capital institucional de trabajo conjunto diputación-municipios que debe servir para abordar otros campos como los servicios personales o la promoción económica. El personal de la diputación debe ser de probada profesionalidad porque, en buena medida, es el mayor activo que la diputación pone al servicio de los municipios. El dinero que puede aportar la diputación se multiplicará si va acompañado por el asesoramiento permanente de los técnicos y directivos que trabajan con los municipios en el diseño y ejecución de un proyecto.

El tratamiento extenso que las diputaciones reciben en este Libro Blanco se justifica porque la Constitución contempla la autonomía de las provincias y deja a la autonomía municipal y a las comunidades autónomas la posibilidad de establecer otras asociaciones de municipios. Está claro que la relación de las diputaciones con estas otras formas de asociacionismo resultan claves para el buen gobierno local. 
La provincia y su órgano de gobierno, la diputación, no agotan la intermunicipalidad pero es la única agrupación de municipios que la Constitución prevé, de ahí que la Ley de Bases deba regular con cierto grado de detalle su condición de agrupación de municipios. No obstante, también es preciso abrir el debate sobre la procedencia de formas de asociacionismo municipal más coherentes en términos territoriales y socioeconómicos, que fortalezcan especialmente a las áreas rurales. Y asimismo es preciso detenerse con la mayor atención en la articulación de los espacios metropolitanos, espacios complejos donde se impone la cooperación y la coordinación de las distintas administraciones públicas y de las diversas políticas sectoriales, como territorios donde se juega el futuro del país.

\section{III}

El tercer gran eje de este Libro Blanco es la organización y funcionamiento del gobierno local. Si tiene sentido el carácter principal de las bases del régimen local es justamente en esta materia. Debe quedar a la potestad de autoorganización de cada ayuntamiento determinar cuales y cuantos son sus órganos complementarios. Así lo dispone el artículo 6.1 de la Carta Europea de la Autonomía Local:

Adecuación de las estructuras y de los medios administrativos a los cometidos de las entidades locales. Sin perjuicio de las disposiciones más generales creadas por la Ley, las entidades locales deben poder definir por si mismas las estructuras administrativas in ternas con las que pretenden dotarse, con objeto de adaptarlas a sus necesidades especí ficas y a fin de permitir una gestión eficaz.

La forma más efectiva de alcanzar la diversidad que demanda el mundo local es dejar en libertad a cada municipio para que, en función de sus prioridades políticas, pueda crear los órganos administrativos más idóneos y seleccionar al personal más adecuado.

En cuanto a los órganos necesarios, el gobierno local debe responder a la dinámica entre mayoría y minoría: quien gana las elecciones debe gobernar y quien las pierde controlar al que ha ganado. No tiene sentido que la oposición gobierne ni que el gobierno tenga que someter al pleno asuntos sin trascendencia política.

La tendencia iniciada con la Ley de Bases que atribuye al alcalde las competencias residuales y configura la comisión de gobierno como un órgano de apoyo, continuada con la reforma de 1999 y culminada con la Ley 57/2003, 
constituye una línea adecuada que equipara el gobierno local al gobierno autonómico y al gobierno de la nación. Si el conflicto político discurre por los cauces gobierno-oposición, por tanto entre mayoría y minoría, el control político no es del pleno sino en el pleno.

El contrapunto a la regulación de la función de gobierno debe ser la garantía de un estatuto de la oposición. En democracia quien gana no lo debe ganar todo y quien pierde no lo debe perder todo, la verdadera calidad de la democracia se mide por el lugar en el que queda la minoría después de unas elecciones. La minoría no está para gobernar y, por tanto, no se explica que haya que reproducir el pleno en todos los órganos de gestión de un ayuntamiento como ocurría con la antigua comisión permanente integrada por todos los grupos municipales. De ser así, estaríamos ante un gobierno de concentración por obra de la ley.

Un estatuto de la oposición debe garantizar plena disposición de los datos y apoyo técnico para ejercer el control político y establecer las condiciones necesarias para el completo desarrollo de esa función. Pero también deben contener las exigencias necesarias para asegurar el cumplimiento por los electos de sus deberes como legítimos y dignos representantes de la comunidad. En definitiva, el estatuto de la oposición es una parte de la regulación del la función representativa, de la participación en el ejercicio de funciones públicas a través de representantes, lo que exige una definición suficiente de los mecanismos institucionales que garanticen el pleno ejercicio de un papel del que en buena medida va a depender la calidad de la democracia local.

También es importante ofrecer una solución razonable a la forma de elección del alcalde, que ha de partir de la consideración de la evidencia de que los ciudadanos, en España, no cuestionan, en términos generales, el presente sistema electoral local (o mejor dicho, "los sistemas"). A partir de esta idea, el Libro Blanco sugiere la introducción de reformas sencillas que no quiebran las líneas maestras del actual sistema electoral y que, sin embargo, permiten a los ciudadanos una incidencia mucho mayor en la elección del cabeza del ejecutivo local.

\section{IV}

Por lo que se refiere a la participación de los ciudadanos y al estatuto de los vecinos, el Libro Blanco parte de la convicción de que, en el contexto de un sistema democrático, la participación de los ciudadanos y de sus organizaciones en la vida pública local constituye un fundamental activo que comple- 
menta la representación política, haciendo a ésta más dinámica y rica, en cuanto le aporta una retroalimentación constante de información, demandas y contacto con la realidad. Es justamente en unos gobiernos de proximidad donde la participación tiene más sentido y es más materializable.

En este ámbito, se considera que la variada e imaginativa experiencia desarrollada en el ámbito local, pone de manifiesto como los ayuntamientos han hecho posible la efectiva participación de los ciudadanos, lo que muestra lo acertado de confiar en el ejercicio de su potestad de autoorganización para la determinación de los procedimientos y órganos a través de los cuáles ha de concretarse, permitiéndose que cada gobierno local de una respuesta adaptada a la realidad de la sociedad a la que representa.

En el ámbito de las relaciones intergubernamentales el Libro Blanco apuesta por el reforzamiento de un modelo basado en la cooperación y en la coordinación de los diversos niveles de poder territorial, partiendo del respeto a las competencias de las distintas administraciones públicas.

La consolidación de la Conferencia Sectorial para Asuntos Locales, de la Conferencia de Ciudades y de la Comisión de Directores Generales responsables en materia de administración local constituyen el marco institucional esencial de esta propuesta, que comprende también la participación de las entidades locales como miembros de pleno derecho de aquellas conferencias sectoriales que afecten a competencias locales.

\section{VI}

Por último, en lo referente a los bienes de las entidades locales, la necesidad de su adecuada inventariación como requisito para una defensa y gestión patrimonial más completa y avanzada constituye el eje de las preocupaciones del Libro Blanco.

Por último, debe subrayarse que este Libro Blanco no pretende ser un va demécum cerrado de soluciones para los problemas del gobierno local en España. Por el contrario, su objetivo esencial es el de abordar una serie de aspectos que se consideran fundamentales, para servir de marco a una amplia discusión entre todos los actores implicados en él, y que están llamados a evaluar estas propuestas y a plantear sugerencias de mejoras, alternativas o soporte, según se aprecie en cada caso por parte de aquellos. 


\section{EL MARCO CONSTITUCIONAL}

\section{UNA AUTONOMÍA LOCAL POLÍTICA EN EL MARCO DE LA CONSTITUCIÓN}

No es habitual que los textos constitucionales desciendan a regular con detalle el nivel local de gobierno; y, ciertamente, nuestra Constitución no puede considerarse una excepción a este respecto. En primer término, el texto constitucional procede en su art. 137 a identificar la tipología general de entidades locales en que se organiza territorialmente el Estado (municipios y provincias), aunque admite la posibilidad de crear otras agrupaciones de municipios distintas a las provincias (art. 141.3). En cualquier caso, es oportuno reseñar que el constituyente no concibió de un modo total y absolutamente uniforme a los entes locales, toda vez que contempló expresamente algunas peculiaridades, como las relativas a las islas (art. 141.4), a los territorios históricos forales (Disposición Adicional Primera) y a Ceuta y Melilla (Disposición Transitoria Quinta). De otra parte, establece algunas reglas básicas acerca de los órganos encargados del gobierno y administración de los municipios y las provincias, deteniéndose en subrayar el carácter democrático de los mismos (arts. 140 y 141.2). Y, en fin, la Constitución menciona las fuentes de financiación precisas para desempeñar las funciones que la ley atribuya a las entidades locales (art. 142 y 133.2), si bien soslaya por completo indicar cuál pueda ser dicho ámbito competencial. Pero muy probablemente el aspecto más reseñable resida en que la entera regulación constitucional se articula en torno a la consagración de la "autonomía" municipal y provincial como principio estructural básico del nivel local de gobierno (arts. 137, 140 y 141.2); principio que, por ende, no sólo resulta obviamente determinante para interpretar y enjuiciar la normativa infraconstitucional, sino que incluso deviene esencial para precisar el alcance y el sentido de cualquier precepto constitucional que afecte a la materia local.

\section{La garantía constitucional de la autonomía local}

\subsection{El núcleo constitucionalmente indisponible de la autonomía local}

Dado el protagonismo que -siguiendo la pauta general en Derecho Comparado- la Constitución confiere al legislador en la concreción del régimen local (y señaladamente en la determinación de las competencias locales), el Tribunal Constitucional recurrió muy pronto a la técnica de la "garantía institucional" para evitar que la autonomía de municipios y provincias quedase a la entera disposición de la normativa infraconstitucional. De acuerdo con la formulación que de dicha garantía ya realizó la STC 32/1981 -y se ha mantenido 
desde entonces-, al legislador «no se fija más límite que el del reducto indisponible o núcleo esencial de la institución que la Constitución garantiza» (FJ $\left.3^{\circ}\right)$. Consecuentemente, proseguiría este fundamento jurídico, «la garantía institucional no asegura un contenido concreto o un ámbito competencial determinado y fijado de una vez por todas, sino la preservación de una institución en términos recognoscibles para la imagen que de la misma tiene la conciencia social en cada tiempo y lugar. [...] En definitiva, la única interdicción claramente discernible es la de la ruptura clara y neta con esa imagen comúnmente aceptada de la institución que, en cuanto formación jurídica, viene determinada en buena parte por las normas que en cada momento la regulan y la aplicación que de las mismas se hace».

Pues bien, esta garantía institucional proyecta su eficacia protectora tanto al plano de la organización como al competencial (SSTC 32/1981, FJ 5 ${ }^{\text {; }}$; 214/1989, FJ $1^{\circ}$ ). En lo concerniente al primero de los ámbitos reseñados, el Tribunal Constitucional no ha dudado en enraizar directamente en el principio de autonomía la obligada existencia de una capacidad decisoria propia local en la determinación de su organización interna.

Como señaló en la STC 214/1989 refiriéndose a los municipios, pero que es sin duda extensible a las provincias, los entes locales disfrutan al respecto de potestad reglamentaria «inherente (...) a la autonomía que la Constitución garantiza en su art. 140" (FJ $\left.6^{\circ}\right)$. Consecuentemente, en la medida en que la potestad de autoorganización ha de considerarse integrante del núcleo esencial de la institución, la legislación estatal y, en su caso, la autonómica que se dicte al respecto habrá de respetar necesariamente un margen de maniobra que se deje a la libre decisión de los entes locales.

Mayor desarrollo ha alcanzado la jurisprudencia constitucional en la determinación de las exigencias que el principio constitucional de autonomía entraña en la esfera de las competencias locales. En efecto, sobre la base de esta concepción de la garantía institucional de la autonomía local, se ha ido decantando una serie de reglas mínimas del orden competencial que, en cuanto definitorias del núcleo indisponible de las instituciones municipal y provincial, vinculan obligatoriamente a toda la normativa infraconstitucional, tanto estatal como autonómica.

En primer término y sobre todo, el principio constitucional de autonomía supone el reconocimiento de que los municipios y provincias han de estar dotados necesariamente de un haz mínimo de competencias. Por consiguiente, la implantación de otras entidades locales contingentes o no necesa- 
rias por parte de las comunidades autónomas puede, ciertamente, conducir a una redistribución de las competencias de aquellos, «pero no eliminarlas por entero» (STC 32/1981, FJ 3o․ . Así, pues, «esa reordenación no puede afectar al contenido competencial mínimo (...) garantizado como imperativo de la autonomía local» [STC 214/1989, FJ $4^{\circ}$ b) ]. Y, de otro lado, como ya tempranamente señaló el Tribunal Constitucional, el principio de autonomía consagrado en el art. $137 \mathrm{CE}$ reclama que tales competencias se asignen a título de competencias propias (STC 4/1981, FJ $3^{\circ}$ ); debiendo entenderse constitucionalmente por competencia propia «la que es desempeñada por su titular bajo un régimen de autorresponsabilidad» (STC 109/1998, FJ 13º ).

Por lo tanto, desde el punto de vista competencial, la garantía de la autonomía local ex art. $137 \mathrm{CE}$ «se proyecta en la exigencia de que el legislador ha de atenerse a un "mínimo competencial", que, como competencias propias, ha de reconocerse al ente local» (STC 109/1998, FJ 2º). Y ello, sencillamente, porque, como ya se apuntó en la STC 32/1981, las nociones de «competencias propias y de servicios mínimos preceptivos» constituyen «elementos imprescindibles constitutivos del núcleo esencial de la institución constitucionalmente garantizada» (FJ $7^{\circ}$ ). En resumidas cuentas, si la Constitución no asegura un concreto ámbito competencial a municipios y provincias fijado de una vez por todas, sí garantiza que se les dote, como mínimo, de aquellas competencias que resulten esenciales para identificar la "imagen comúnmente aceptada de la institución". Y, en esta línea, el Tribunal Constitucional ya ha tenido ocasión de considerar integrante del «núcleo de la autonomía provincial» la competencia de cooperación económica a la realización de las obras y servicios municipales (STC 109/1998, FJ 2º ); o ha afirmado que sobre el plan urbanístico se proyectan «de forma especialmente intensa las exigencias de la autonomía municipal» (STC 51/2004, FJ 12º), profundizando así en una línea jurisprudencial que subrayaba la relevancia del urbanismo como competencia esencial de los municipios (así, por ejemplo, SSTC 40/1998, FJ 39; 159/2001, FJ $\left.4^{\circ}\right)$.

1.2 La protección constitucional frente a intromisiones en el ámbito de competencias le galmente asignado

Pero la garantía constitucional de la autonomía local, en su dimensión competencial, no se circunscribe a operar en el momento de la delimitación de las competencias locales, imponiendo al legislador el reconocimiento de aquellas competencias mínimas consustanciales a la institución sin las cuales municipios y provincias dejarían de ser reconocibles como tales entes locales. Asimismo, la Constitución brinda cierta protección a la totalidad de las com- 
petencias propias que se atribuya legalmente a las entidades locales frente a determinadas intromisiones e injerencias provenientes de otros niveles de gobierno; y ello con independencia de que las mismas formen parte o no de ese "núcleo esencial competencial" identificador de la institución municipal o provincial. En efecto, aun cuando se trate de competencias locales "de creación legal" - esto es, de competencias "no esenciales", en cuanto no derivadas directa y necesariamente del principio de autonomía constitucionalmente consagrado- no puede en modo alguno admitirse que las mismas queden a la entera disponibilidad de los restantes niveles de gobierno, sin atadura ni cortapisa alguna. El principio de autonomía local, pues, también extiende su manto protector a las competencias propias "de creación legal".

Que el Estado o las comunidades autónomas, ope Constitutionis, no pueden operar a su sazón, de forma incondicionada, en el ámbito de las competencias propias asignadas legalmente, es una apreciación que el Tribunal Constitucional pronto hizo suya, al afirmar categóricamente que no era dable cualquier intervención gratuita en dicha esfera: «El legislador puede disminuir o acrecentar las competencias hoy existentes, pero no eliminarlas por entero, y, lo que es más, el debilitamien to de su contenido sólo puede hacerse con razón suficiente y nunca en daño del principio de autonomía...» [SSTC 32/1981, FJ 3o; 214/1989, FJ 13 c) ]. Al cerrarse, así, el paso a toda erosión de las competencias locales carente de la suficiente motivación, el Tribunal Constitucional parece estar evocando otras fórmulas de control de la arbitrariedad más perfiladas, como el principio de proporcionalidad, que se emplean en otros ordenamientos para preservar la autonomía local. De hecho, nada se opone a que el principio de proporcionalidad juegue también una función semejante entre nosotros: De una parte, como tantas veces ha reiterado el Tribunal Constitucional, el principio de proporcionalidad tiene un específico anclaje constitucional, al considerarse un elemento inherente a la cláusula del Estado de Derecho (art. 1.1 CE) y al principio de interdicción de la arbitrariedad de los poderes públicos (art. 9.3 CE). Y, de otra parte, aunque es cierto que en la jurisprudencia constitucional se ha subrayado la especial aplicación que tiene el principio de proporcionalidad para proteger a los derechos fundamentales frente a limitaciones o restricciones, en modo alguno se ha negado la posibilidad de que el mismo sirva para enjuiciar el eventual quebrantamiento de otros preceptos constitucionales (por todas, STC 55/1996, FJ $3^{\circ}$ ). No es de extrañar, por tanto, que, siquiera tímidamente, el criterio de la proporcionalidad ya haya hecho acto de presencia para valorar si determinados condicionantes impuestos a las entidades locales se acomodan, o no, a la autonomía local constitucionalmente garantizada (así, STC 109/1998, FJ 11º). 
Por otro lado, el hecho de que las competencias propias locales deban desempeñarse «bajo un régimen de auto responsabilidad» impone ciertas restricciones a las posibilidades de actuación que pretendan desplegar el Estado o las comunidades en ejercicio de sus atribuciones. Pues -como suele reconocerse en otros ordenamientos- la noción de "auto responsabilidad" resulta, lisa y llanamente, incompatible con el establecimiento de instrucciones vinculantes por parte de otros niveles de gobierno, razón por la cual sólo suelen admitirse técnicas de control de legalidad. Así, ya en la STC 4/1981 se declaró taxativamente que no se ajustaba al principio de autonomía local «la previsión de controles genéricos e indeterminados que sitúen a las entidades locales en una posición de subordinación o dependencia cuasi jerárquica de la administración del Estado u otras entidades territoriales» (FJ $\left.3^{\circ}\right)$. Mientras que, por el contrario, y en línea de principio, «los controles administrativos de legalidad no afectan al núcleo central de la autonomía de las Corporaciones Locales» (ibidem; asimismo, por ejemplo, SSTC 46/1992, FJ 2º y 11/1999, FJ 2º).

En consecuencia, como una exigencia derivada directamente del principio de autonomía constitucionalmente consagrado, ha de entenderse que la esfera de las competencia propias locales acota un ámbito en el que necesariamente debe preservarse la capacidad decisoria del Ente local, por más que otro nivel de gobierno pueda alegar un título de intervención en principio lícito. Así se desprende con toda evidencia, por mencionar algún ejemplo, de la STC 27/1987, en donde se concluyó que, si bien las facultades coordinadoras de una Comunidad autónoma pueden suponer un límite al ejercicio de las competencias locales, en modo alguno pueden llegar a la práctica anulación de las mismas: «[La coordinación] no puede traducirse en la emanación de órdenes concretas que prefiguren exhaustivamente el contenido de la actividad del ente coordinado, agotando su propio ámbito de decisión autónoma; en cualquier caso, los medios y técnicas de coordinación deben respetar un margen de libre decisión o de discrecionalidad en favor de las administraciones sujetas a la misma, sin el cual no puede existir verdadera autonomía» (FJ 6º; véase asimismo la STC 109/1998, FJ 13º).

\section{El desarrollo normativo del régimen local. La función del legislador básico}

Prácticamente desde el comienzo de su actividad -desde que en la STC 4/1981 apuntó que cabía deducir de los arts. 148.1.2 y 149.1.18 CE un «mandato implícito» para que se dictase una nueva Ley de régimen local [FFJJ $1^{\circ} \mathrm{B}$ ) y $\left.3^{\circ}\right]$-, el Tribunal Constitucional ha venido sosteniendo ininterrumpidamente que, en primera instancia, corresponde al Estado el desarrollo normativo del nivel local de gobierno, en virtud de la competencia que ostenta sobre las "bases del régimen jurídico de las administraciones públicas” (art. 149.1.18). La 
conexión directa que media entre esta competencia normativa y, de una parte, la concreción de la garantía constitucional de la autonomía local y, de otro lado, el aseguramiento de un determinado modelo de Estado, es la razón primordial esgrimida para sustentar esta interpretación del título competencial $e x$ art. 149.1.18 CE: «Como titulares de un derecho a la autonomía constitucionalmente garantizada, las comunidades locales no pueden ser dejadas en lo que toca a la definición de sus competencias y la configuración de sus órganos de gobierno a la interpretación que cada comunidad autónoma pueda hacer de ese derecho (...) La garantía constitucional es de carácter general y configuradora de un modelo de Estado, y ello conduce, como consecuencia obligada, a entender que corresponde al mismo la fijación de principios o criterios básicos en materia de organización y competencia de general aplicación en todo el Estado» (STC 32/1981, FJ 5º; desde entonces, doctrina profusamente reiterada). En definitiva, si, por lo general, con la atribución al Estado de la competencia para determinar las bases de una materia se pretende «una regulación normativa uniforme y de vigencia en toda la Nación» (por todas, STC 1/1982, FJ $1^{\circ}$ ), así también la normativa básica estatal ex art. 149.1.18 CE «tiende a asegurar un nivel mínimo de autonomía a todas las Corporaciones locales en todo el territorio nacional, sea cual sea la comunidad autónoma en que estén localizadas» (así, entre otras, SSTC 213/1988, FJ 2ํㅜ y 259/1988, FJ 2oㅜ).

De conformidad con estos presupuestos doctrinales, se hace evidente que el componente fundamental de "lo materialmente básico" se halla constituido por aquellas cuestiones más estrechamente relacionadas con la delimitación de la autonomía constitucionalmente consagrada, a saber, la estructura orgánica y -sobre todo competencial de municipios y provincias (y así lo recuerda constantemente el Tribunal Constitucional -SSTC 32/1981, FJ 5º; 214/1989, FJ 1ㅜ; STC 33/1993, FJ 3º; etc.-). No es de extrañar, pues, que haya sido precisamente a propósito de la regulación de las competencias cuando el Tribunal Constitucional ha destacado que el legislador básico desempeña una «función constitucional», consistente en "garantizar los mínimos competenciales que dotan de contenido y efectividad a la garantía de la autonomía local» (SSTC 214/1989, FJ $3^{\circ}$ y $159 / 2001$, FJ $4^{\circ}$ ). Sin embargo, como no es menos obvio, la competencia estatal ex art. 149.1.18 CE no se detiene en la normación de estas cuestiones imprescindibles para precisar el alcance constitucional del principio de autonomía local. Pues, más allá de estos integrantes indubitados de las bases estatales, la jurisprudencia constitucional ha ido paulatinamente perfilando un grupo de concretas materias a las que es dable aplicar la conceptuación de "básicas" en el marco del art. 149.1.18 CE. Así, sin ánimo de ser exhaustivos, se ha considerado comprendida en este título competencial la regulación estatal de los siguientes asuntos: 
-Determinación del quórum y las mayorías precisas para adoptar acuerdos por parte de los órganos de gobierno [SSTC 33/1993, FJ $3^{\circ}$ y $331 / 1993, \mathrm{FJ}^{\circ}{ }^{\circ} \mathrm{A}$ ) ].

-Sistema de controles de legalidad (así, por ejemplo, SSTC 27/1987, FJ 2º; 213/1988, FJ 2º; 46/1992, FJ 2º; 11/1999, FJ 2º).

-Impugnación de actos y acuerdos de las entidades locales por parte del Estado y de las comunidades autónomas [STC 331/1993, FJ 4º C].

-Relaciones interadministrativas, previendo, por ejemplo, fórmulas de coordinación entre las diferentes administraciones y la delegación de funciones a las entidades locales (entre otras, SSTC 76/1983, FJ $18^{\circ}$ y $27 / 1987$, FJ $2^{\circ}$ ).

-Demarcaciones supramunicipales (STG 179/1985, FJ 2º)

-Fijación de los requisitos que han de satisfacerse para la creación de municipios (STC 214/1989, FJ 8o).

-Régimen de incompatibilidades de los miembros de las entidades locales [STC 331/1993, FJ $4^{\circ}$ B)].

-Denominación y capitalidad de las provincias (STC 385/1993, FJ 4ํ).

Una vez identificados algunos de los ámbitos en los que puede legítimamente desplegarse la competencia estatal sobre las bases, y a poco que se reflexione, podrá fácilmente llegarse a la conclusión de que, al acometer la regulación de las bases del régimen local, el legislador desempeña dos tareas de naturaleza asaz diferente. Por una parte, operando con eficacia meramente declarativa, ha de hacer ver al conjunto de los operadores jurídicos los elementos integrantes de la autonomía local que cabe considerar directa e inmediatamente protegidos por el propio texto constitucional. $\mathrm{O}$, para decirlo con los términos empleados en la STC 148/1991, al Estado corresponde en primer término explicitar cuál es «el contenido esencial de la autonomía local garantizado directamente por el art. $137 \mathrm{CE}$ » (FJ $4^{\circ}$; la cursiva es nuestra). Y, naturalmente, dado que se trata de un «contenido mínimo que el Legislador debe respetar» (STC 46/1992, FJ 2º), en esta tarea consistente en hacer aflorar los componentes de la autonomía local constitucionalmente protegidos, el legislador básico carece de cualquier margen de maniobra posible, pues se limita a desvelar lo que ya está implícitamente delimitado en la Constitución misma.

Pero, de otro lado, el legislador estatal está facultado para ampliar o mejorar ese "contenido constitucionalmente indisponible" de la autonomía local, 
incorporando otras garantías o sumando nuevas competencias a las definitorias del contenido esencial de la institución. Pues, ciertamente, «más allá de este contenido mínimo, la autonomía local es un concepto jurídico de contenido legal, que permite, por tanto, configuraciones diversas, válidas en cuanto respeten esa garantía institucional» (STC 46/1992, FJ $2^{\circ}$ ).

Pues bien, en la determinación de este -por utilizar nuevamente los términos de la STC 148/1991- contenido básico de la autonomía local, sí cuenta el Estado con plena libertad de configuración política, pudiendo consecuentemente optar ad libitum -siempre que se mantenga en los límites del art. 149.1.18 CE, claro está- por el diseño de una Ley de Bases dotada de mayor o menor extensión y densidad normativas. Se trata, sencillamente, de una mera opción política, que, en cuanto tal, escapa al control jurisdiccional: «El legislador estatal, en el ejercicio de la competencia que le reconoce el art. 149.1.18. a de la Constitución, ha optado aquí, como en otros supuestos, por ampliar el alcance y contenido de la autonomía municipal, sin que a ello pueda imputarse exceso competencial de ningún tipo, al ser simple concreción de una legítima opción política que, cualquiera que sea la valoración que pueda suscitar, constitucionalmente no permite juicio alguno de este Tribunal» [STC 214/1989, FJ $14^{\circ}$ a); véase en la misma línea, por ejemplo, las SSTC 27/1987, FJ 9º; 213/1988, FJ 2º; 146/1991, FJ $4^{\circ}$ y 46/1992, FJ 2ํㅡ.

Esta doble naturaleza de la función que acomete el Estado al desarrollar normativamente el régimen local ha sido descrita en términos sumamente esclarecedores en la STC 159/2001:

«Esta ley [LBRL] puede a priori contener, de un lado, tanto los rasgos definitorios de la autonomía local, concreción directa de los arts. 137, 140 y 141 $\mathrm{CE}$, como, de otro, la regulación legal del funcionamiento, la articulación o la planta orgánica (entre otras cosas) de los entes locales. Sólo aquellos extremos de la LBRL que puedan ser cabalmente enraizados de forma directa en los arts. 137, 140 y $141 \mathrm{CE}$, de cuyo contenido no representen más que exteriorizaciones o manifestaciones, forman parte del contenido de la autonomía local constitucionalmente garantizada, mientras que los que se refieran a aspectos secundarios o no expresivos de ese núcleo esencial en el que consiste la garantía institucional, que son mayoría en el seno de la LBRL y que se incardinan, desde el punto de vista competencial, en el art. 149.1.18 CE, tienen una distinta naturaleza desde el punto de vista constitucional y ordinamental» $\left(\mathrm{FJ} 4^{\circ}\right)$.

Por lo demás, no por bien conocido puede dejar de reseñarse que el legislador básico, si bien cuenta con una margen de libertad de opción al regu- 
lar los «aspectos secundarios o no expresivos» del contenido esencial de la autonomía local, encuentra un obstáculo infranqueable en las competencias autonómicas en materia de régimen local, que en ningún caso pueden ser neutralizadas por una normativa estatal pormenorizada y penetrante en exceso. Así vino el Tribunal Constitucional a asegurarlo en una de sus primeras decisiones: «La fijación de estas condiciones básicas no puede implicar en ningún caso el establecimiento de un régimen uniforme para todas las entidades locales de todo el Estado, sino que debe permitir opciones diversas, ya que la potestad normativa de las comunidades autónomas no es en estos supuestos de carácter reglamentario» (STC 32/1981, FJ 5º; doctrina que se reitera, por ejemplo, en las SSTC 27/1987, FJ $3^{\circ}$ y $33 / 1993$, FJ $3^{\circ}$ ). Pues bien, por lo que hace a la vertiente competencial, de conformidad con esta doctrina, lo que resulta vedado al legislador básico es que descienda a la «fijación detallada» de las competencias locales (por todas, SSTC 214/1989, FJ $3^{\circ}$ y $159 / 2001$, FJ $4^{\circ}$ ); prescripción que no se ha entendido vulnerada por el vigente sistema de la Ley de Bases, pues, por más que establezca reglas de alcance general (art. 2.1) y precise los servicios mínimos municipales, se deja un margen de opción a las comunidades autónomas, ya que «la concreción última de las competencias locales queda remitida -y no podría ser de otra manera- a la correspondiente legislación sectorial, ya sea estatal o autonómica, según el sistema constitucional de distribución de competencias entre el Estado y las comunidades autónomas» (STC 214/1989, FJ 3o․ . Y en lo concerniente a la regulación de las estructura orgánica, el límite que encuentra el legislador básico consiste, asimismo, en que no debe eliminar «la posibilidad de todo espacio normativo para la legislación autonómica de desarrollo en materia de organización» (STC 214/1989, FJ $6^{\circ}$ ).

Como hemos constatado líneas arriba, de la jurisprudencia constitucional se desprende que la finalidad esencial de la atribución al legislador estatal de la competencia básica $e x$ art. 148.1.18 CE reside en permitir el establecimiento de un nivel de autonomía local homogéneo en todo el Estado y, con ello, la instauración de un "modelo local común".

Ahora bien, debe asimismo notarse que el Tribunal Constitucional no ha concebido esa finalidad en términos de total y absoluta uniformidad, pues no ha cerrado completamente el paso a la posibilidad de que, junto al régimen general establecido por la normativa básica, convivan determinadas peculiaridades autonómicas. Así, además de las singularidades constitucionalmente previstas, como la de las diputaciones forales (STC 214/1989, FJ 26으), se ha tolerado la exceptuación de las bases en aquellos supuestos en que, «en algún aspecto concreto, su inaplicación resulte expresa e inequívocamente de lo dis- 
puesto en el Estatuto de Autonomía de una determinada comunidad, como una característica específica de la misma» (STC 27/1987, FJ 9º). En definitiva, de acuerdo con esta línea jurisprudencial, «no empece en absoluto» a la noción constitucional de "bases" "el hecho de que, junto al régimen básico aplicable a la generalidad de las comunidades autónomas, coexistan situaciones particulares; aunque estas excepciones precisan ineludiblemente, bien una expresa habilitación constitucional... bien [...] un específico anclaje estatutario (STC 109/1998, FJ 3ํo).

\section{La dimensión financiera de la autonomía local}

Por lo que hace a la vertiente financiera del régimen local, también la Constitución encomienda en primera instancia al Estado la concreción de su alcance y significado. E, incluso, cabría apuntar que su posición a este respecto se ve reforzada por la concurrencia de dos títulos competenciales, toda vez que, junto al art. 149.1.18 CE, puede asimismo esgrimir su competencia sobre la "Hacienda general" (art. 149.1.14 CE). Mientras que el primero de los mencionados entra en juego cuando la regulación estatal «suponga introducir modificaciones de alcance general en el régimen jurídico de la administración local o se dicte en garantía de la autonomía que ésta tiene constitucionalmente garantizada»; ha de entenderse que se ejercita la competencia exclusiva sobre la "Hacienda general" cuando «la normativa estatal tenga por objeto la regulación de las instituciones comunes a las distintas Haciendas o de medidas de coordinación entre la Hacienda estatal y las Haciendas de las Corporaciones Locales», así como cuando la finalidad de la misma «sea la salvaguarda de la suficiencia financiera de las Haciendas locales garantizada por el art. $142 \mathrm{CE}$ » [STC 233/1999, FJ $4^{\circ}$ B) ]. En todo caso, cualesquiera que sean los puntos de separación y contacto entre ambos títulos competenciales, lo que sí resulta indubitado es que corresponde a la competencia estatal el diseño del sistema de financiación de las entidades locales [STC 179/1985, FJ 1ㅜㅜ reiterado en la STC 233/1999, FJ $4^{\circ}$ B) ]. Tarea para la que el legislador estatal dispone de cierta «libertad de configuración» (STC 192/2000, FJ 10º), siempre y cuando se atenga -como es palmario- a los límites necesarios que se derivan de la consagración constitucional de la autonomía financiera local.

Veamos en qué consisten tales límites.

\subsection{La garantía constitucional de la suficiencia financiera}

La suficiencia de ingresos constituye, obviamente, el presupuesto material inexcusable de la autonomía financiera -de la autonomía, sin más-; razón 
por la cual el constituyente quiso garantizarla expresamente en el art. 142 CE. Dado el reparto competencial existente en materia de Hacienda local, se hace evidente que este mandato de suficiencia financiera se dirige en primer término y sobre todo al Estado (así, por ejemplo, STC 233/1999, FJ 22º), aunque el aludido precepto constitucional, al establecer en términos imperativos que las Haciendas locales, entre otros recursos, "se nutrirán" de una participación en los tributos de las comunidades autónomas, está con toda evidencia imponiendo la necesaria participación de éstas en la dotación de los recursos precisos para el mantenimiento de las competencias locales. No obstante, sea cual fuere la vía a través de la cual dicho compromiso se articule, lo que sí resulta constitucionalmente obligado es que el reparto de los fondos entre las diferentes entidades locales habrá de efectuarse «conforme a criterios objetivos y razonables, pues en caso contrario podrían resultar vulnerados los principios constitucionales de igualdad e interdicción de la arbitrariedad de los poderes públicos» (STC 150/1990, FJ 12º). Por lo demás, dando un paso más en la delimitación del sentido del principio de suficiencia, el Tribunal Constitucional ya ha tenido la ocasión de indicar que el mismo no impide, en modo alguno, que los recursos de las entidades locales «superen la cifra precisa para cubrir las necesidades del municipio o, dicho de otro modo, no se opone a que exista superávit presupuestario» (STC 233/1999, FJ 22º $)$.

\subsection{La autonomía financiera local en la vertiente de los ingresos}

El artículo 142 CE menciona a los tributos propios entre las fuentes de financiación necesarias de la Hacienda local, aunque no se detiene a precisar el alcance del concepto y, por tanto, a determinar si los entes locales han de disponer obligatoriamente de cierto poder normativo en la configuración de los mismos. Sin embargo, la preceptiva lectura de la norma a la luz del principio de autonomía no puede sino conducir a la conclusión de que, en efecto, la atribución de un cierto margen de maniobra local al respecto resulta constitucionalmente obligada. $Y$ así ha venido a reconocerlo -como no podía ser de otra manera- el Tribunal Constitucional, que reiteradamente ha señalado que la autonomía local «posee también una proyección en el terreno tributario», debiendo en consecuencia el legislador, no sólo asignar a las entidades locales determinados tributos propios, sino también «reconocerles una intervención en su establecimiento o exigencia, según previenen los arts. 140 y 133.2 de la Norma fundamental» (STC 221/1992, FJ 8ㅜㅜ asimismo, por ejemplo, STC 19/1987, FJ 5 $5^{\circ}$ ). Así, pues, «en virtud de la autonomía de los entes locales constitucionalmente garantizada y del carácter representativo del Pleno de la Corporación municipal, es preciso que la Ley estatal atribuya a los Acuerdos adoptados por éste (así, los acuerdos dimanantes del ejercicio de la 
potestad de ordenanza), un cierto ámbito de decisión acerca de los tributos propios del Municipio» [STC 233/1999, FJ 10ㅜ C) ]. Por el contrario, no se ha considerado una consecuencia obligada del principio de autonomía el que la intervención normativa de la Entidad local tenga que extenderse necesariamente «a todos y cada uno de los elementos integrantes del tributo» (SSTC 221/1992, FJ $8^{\circ}$ y $233 / 1999$, FJ $22^{\circ}$ ) ; y tampoco se ha entendido que sea un componente esencial de la autonomía tributaria la facultad de determinar libremente imponer, o no, cada uno de los tributos propios, admitiéndose, por ende, la fijación de impuestos obligatorios de las entidades locales (STC 233/1999, FJ 22ㅇ).

Más allá de esas concretas acotaciones del alcance de la autonomía tributaria local, ha de tenerse presente que el margen de maniobra que puede reconocerse a las entidades locales en esta esfera se halla sustancialmente condicionado por las exigencias derivadas del principio de reserva de ley en materia tributaria. Y es que, ciertamente, no puede «el legislador abdicar de toda regulación directa en el ámbito parcial que así le reserva la Constitución (art. 133.1 y 2)»; como tampoco queda a su disposición renunciar al «establecimiento de toda limitación en el ejercicio de la potestad tributaria de las Corporaciones Locales» (STC 19/1987, FJ 5º̄). De ahí que, en aplicación de estos criterios, se considerase inconstitucional la fijación libre por parte de las entidades locales de un recargo sobre el IRPF y de los tipos de las contribuciones territoriales (SSTC 179/1985 y 19/1987). Ahora bien, dicho lo anterior, no debe soslayarse que la más reciente jurisprudencia constitucional ha efectuado una lectura de dicha reserva más atenta al principio de autonomía local, suavizando consecuentemente su alcance en pro del reconocimiento de una mayor libertad de configuración local al respecto. Así, no ha dudado en reconocer expresamente que la reserva de ley en materia tributaria se proyecta en términos menos rigurosos sobre las entidades locales que sobre la administración del Estado, admitiendo que su ámbito de libre decisión es «desde luego, mayor que el que pudiera relegarse a la normativa reglamentaria estatal» [STC 233/1999, FJ 10ㅇ C) ]. Y, en este sentido, se ha considerado que la facultad de determinar la cuota o el tipo impositivo, dentro de los márgenes fijados por la Ley, constituye un mínimo que cabe inferir directamente del propio texto constitucional, al tratarse de «uno de los elementos indiscutiblemente definidores de la autonomía local» (STC 233/1999, FJ $26^{\circ}$ ).

Finalmente, por lo que hace a la capacidad de los entes locales de determinar el volumen de sus recursos, conviene asimismo reseñar que la autonomía financiera también se manifiesta en materia de endeudamiento, de tal suerte que un necesario margen de disposición al respecto «ha de ser reco- 
nocido a las Corporaciones Locales por imperativo del principio constitucional de autonomía local» (STC 233/1999, FJ 21ㅜ).

\subsection{La autonomía financiera local en la vertiente del gasto}

El Tribunal Constitucional ha derivado del art. 142 CE, en conexión con el art. $137 \mathrm{CE}$, la existencia de la autonomía de gasto de los entes locales, «entendiendo por tal la capacidad genérica de determinar y ordenar, bajo la propia responsabilidad, los gastos necesarios para el ejercicio de las competencias conferidas» (STC 109/1998, FJ 10º). Y la ha concebido, ciertamente, en términos muy generosos, como lo acredita el hecho de que haya considerado aplicable en lo fundamental la doctrina inicialmente acuñada en relación con las comunidades autónomas. Pues, al igual que sucede con éstas, se ha entendido que también para las entidades locales esta garantía «entraña, en línea de principio, la plena disponibilidad de sus ingresos, sin condicionamientos indebidos y en toda su extensión, para poder ejercer las competencias propias» (SSTC 237/1992, FJ 6ㅜ; 109/1998, FJ 10º). Y si bien es verdad que «el ámbito sobre el que se proyecta la autonomía de gasto provincial no ha de concebirse como una esfera total y absolutamente resistente a cualquier mínima incidencia o afectación proveniente de otros niveles de gobierno», no es menos cierto que la misma sólo puede ser restringida por el Estado o las comunidades autónomas «dentro de los límites establecidos en el bloque de la constitucionalidad» (STC 109/1998, FJ 10º ).

La principal consecuencia que cabe extraer de esta línea jurisprudencial es que las fuentes ordinarias y permanentes de financiación de las competencias propias han de suministrar necesariamente ingresos que resulten de libre disposición para los entes locales, limitándose, pues, las subvenciones condicionadas a actuar como mecanismos de financiación meramente complementarios, que sólo pueden entrar en juego una vez que aquéllas han satisfecho el mandato de suficiencia financiera. Y por último, y no por ello menos importante, la autonomía de gasto se opone frontalmente a que pueda imponerse a las entidades locales la obligación de financiar, con sus propios recursos, las competencias cuya titularidad corresponda a otros niveles de gobierno (STC $48 / 2004, \mathrm{FFJJ} 10^{\circ}$ y $\left.11^{\circ}\right)$.

II.-EL MARCO EUROPEO DE LA REFORMA DEL GOBIERNO Y LA ADMINISTRACIÓN LOCAL EN ESPAÑA

UNOS GOBIERNOS LOCALES BASADOS EN EL ACERVO EUROPEO SOBRE LA AUTONOMÍA LOCAL 


\section{Diagnóstico}

Es indudable que cualquier reforma del gobierno y la administración local en España ha de inspirarse en el acervo europeo en la materia, recogido sustancialmente en el conjunto de Recomendaciones y Convenios del Consejo de Europa sobre la democracia local, y especialmente en la Carta Europea de Autonomía Local (en adelante CEAL), ratificada por España, como "constitución” europea del régimen local, así como en el principio de subsidiariedad y de proporcionalidad, consagrado en el derecho de la Unión Europea y en el Tratado de la Constitución Europea.

De entrada, debe resaltarse que el preámbulo de la Carta Europea de la Autonomía Local destaca que "el derecho de los ciudadanos a participar en la ges tión de los asuntos públicos forma parte de los principios democráticos comunes a todos los Estados miembros del Consejo e Europa", y que es "en este nivel local donde este de recho puede ser ejercido más directamente". Por ello resulta de la mayor importancia destacar la relevancia que merece la participación de los ciudadanos en los gobiernos que les son más cercanos, y donde ésta se puede practicar más adecuadamente. Una participación que no desplaza la democracia representativa, sino que la enriquece y la hace más comprometida, por el contacto y la retroalimentación directa de los electos con los ciudadanos y sus organizaciones. $\mathrm{Y}$ donde existe todo un amplio y diverso abanico de experiencias, que constituye un verdadero campo de pruebas para el fortalecimiento de la relación constante entre la sociedad civil y las legítimas instituciones representativas locales.

El artículo 3.1 de la CEAL contiene un concepto de autonomía local avanzado y ambicioso, al disponer que por autonomí local se entiende el derecho y la capacidad efectiva de las entidades locales de ordenar y gestionar una parte importante de los asuntos públicos, en el marco de la ley, bajo su propia responsabilidad y en beneficio de sus habitantes. En nuestro ordenamiento jurídico positivo no existe ninguna otra definición de lo que debe entenderse por autonomía local.

Desde el punto de vista material, el artículo 3.1 de la CEAL incorpora en la noción de autonomía local, el derecho y la capacidad de "ordenar" una parte importante de los asuntos públicos o, lo que es lo mismo, atribuye a las entidades locales competencias de normación sobre esa parte importante de asuntos públicos.

En ese mismo orden de cosas el artículo 4.1 de la LRBRL reconoce a los entes locales, dentro de la esfera de sus competencias, la potestad reglamenta- 
ria, pero, como advierte el Congreso de los Poderes Locales y Regionales de Europa en su Recomendación núm. 121, de 14 de noviembre de 2002, sobre la democracia local y regional en España (parágrafo 15), la autonomía normativa de las colectividades locales en España corre el peligro de verse limitada por dos fenómenos confluentes, a saber: por la existencia, por un lado, del ejercicio del poder reglamentario dotado de un gran número de disposiciones de detalle contenidas en las leyes nacionales y de las comunidades autónomas; por el otro, por disposiciones pre vistas en la ley nacional o en las de las comunidades autónomas del régimen en materia de ejecución forzosa, de inspección o sanción, lo que reduce en gran manera la capacidad de las colectividades locales de regular el ejercicio de sus propias competencias.

Además, desde la perspectiva del ejercicio de competencias por parte de las entidades locales y bajo la rúbrica "alcance de la autonomía local", el artículo 4.3 de la CEAL establece que el ejercicio de las competencias públicas debe, de modo general, incumbir preferentemente a las autoridades más cercanas a los ciudadanos. La atribución de una competencia a otra autoridad, añade, debe tener en cuen ta la amplitud o la naturaleza de las tareas, o las necesidades de eficacia o economía. En definitiva, la CEAL proclama el principio de proximidad en el ejercicio de competencias públicas, en favor de las entidades locales.

Tras la promulgación de la CEAL, el derecho de la Unión Europea y del Tratado de la Constitución Europea han incorporado los principios de subsidiariedad y proporcionalidad como principios fundamentales del reparto de competencias en la Unión. Así, el artículo I.11 del Tratado de la Constitución Europea establece que el ejercicio de competencias de la Unión se rige por los principios de subsidiariedad y proporcionalidad y añade:

“3. En virtud del principio de subsidiariedad, en los ámbitos que no sean de su competencia exclusiva la Unión intervendrá sólo en la medida en que los objetivos de la acción considerada no puedan ser alcanzados de manera suficiente por los Estados miembros ni a nivel central ni a nivel regional y local, sino que puedan alcanzarse me jor, debido a la dimensión o a los efectos de la acción considerada, a escala de la Unión.

Las instituciones de la Unión aplicarán el principio de subsidiariedad de confor midad con el Protocolo sobre la aplicación de los principios de subsidiariedad y propor cionalidad. Los Parlamentos nacionales velan por el respeto de dicho principio con arre glo al procedimiento establecido en el Protocolo mencionado.

4. En virtud del principio de proporcionalidad, el contenido y la forma de la acción de la Unión no excederán de lo necesario para alcanzar los objetivos de la Constitución. 
Las instituciones aplicarán el principio de proporcionalidad de conformidad con el Protocolo mencionado en el apartado 3."

Es importante señalar que el Tratado constitucional contempla la existencia de cuatro niveles de gobierno: europeo, estatal, regional y local, haciendo jugar al principio de subsidiariedad en todos ellos. Pero, lo que interesa destacar ahora es que el artículo 4 de la CEAL dispone que las competencias encomendadas a las entidades locales deben de ser normalmente plenas y completas, cosa que no sucede en España. No debe extrañarnos, pues, que la Recomendación del Congreso de los Poderes Locales y Regionales de Europa, de 14 de noviembre de 2002, haya invitado a las autoridades nacionales y regionales españolas a reflexionar sobre los medios de atribución de competencias plenas y totales a sus colectividades locales (parágrafo 17), en base a la siguiente consideración (parágrafo 16):

"16. Estima, a este respecto, que el recurso excesivo a la delegación en cuanto a la atribución de competencias plenas y totales, y la práctica frecuente de fragmentar las competencias y de repartir las partes de responsabilidad entre los distintos escalones de administración (la ley nacional impone la atribución de competencias en ciertos ámbi tos, pero estas competencias también pueden reducirse a la participación de la colectivi dad local en el ejercicio de competencias confiadas a otros ámbitos de gobierno) parece contraria al principio de atribución de competencias plenas y totales, asi como al prin cipio de atribución a las colectividades locales de la "parte importante de los asuntos pú blicos" de la que habla el artículo 3.1 de la Carta”.

Obsérvese que esta invitación ha sido cursada a las autoridades nacionales y regionales, lo que pone de manifiesto el carácter bifronte de las entidades locales españolas. Ahora bien, es sabido que en Europa existen Estados compuestos como Alemania en los que la legislación federal no interviene, en principio, en la organización de las entidades locales y la fijación de sus competencias, pero como recoge el informe del Comité Director para la Democracia Local y Regional del Consejo de Europa sobre la regionalización y sus consecuencias sobre la autonomía local el hecho de que el artículo 28.2 de la Ley Fundamental de Bonn garantice a los municipios el derecho de resolver, bajo su propia responsabilidad y de acuerdo con las leyes, todos los asuntos de la comunidad local, permite a los Länder ampliar el campo de aplicación de la autonomía local ofrecida por dicho precepto, pero no limitarla.

Todo ello supone, a juicio de los autores del citado informe, que las com petencias fundamentales de las entidades locales en los Länder respectivos son idénticas y que sólo existen diferencias en lo referente a la atribución de tareas determinadas, y 
que el principio que rige es que siempre que la ley no disponga expresamente otra cosa, la administración pública es responsabilidad exclusiva de las entidades locales en los límites de su territorio, lo que significa que la competencia general de las entidades locales cubre una amplia gama de tareas y competencias diversas. En España, en cambio, las competencias propias de las entidades locales son escasas, como lo demuestra el hecho de que apenas suponen el 15 por ciento del gasto público español, dándose la circunstancia añadida de que parte de ese gasto obedece a competencias impropias.

En este orden de cosas el informe sobre democracia local y regional en España, elaborado por la Comisión de expertos del Congreso de los Poderes Locales y Regionales de Europa, explica el motivo o motivos de las escasas competencias de las entidades locales españolas con estas certeras palabras (parágrafos 64 y 65):

“64) Varios factores han favorecido la centralización de las competencias en el pla no regional. En primer lugar, la tendencia natural de las nuevas instituciones a conso lidar las relaciones con los ciudadanos a través del cumplimiento directo de las tareas administrativas.

65) En segundo lugar, una dificultad objetiva para encontrar en las colectivida des locales temas adecuados para el ejercicio de las competencias. En este sentido, pense mos, por un lado, en la fragmentación de la red administrativa de los municipios, la mayoría de los cuales no están adaptados para ejercer dicho papel por motivos de dimensión territorial insuficiente y de población; y por el otro, en la inadecuación de las provincias; mientras, éstas siguen dibujándose como organismos de segundo orden des tinados a permitir el ejercicio de las funciones de los municipios y no como potenciales destinatarios directos de competencias (sobre todo las relacionadas con los más amplios y que, debido a su tamaño, se mantienen en plano regional)".

En otro orden de cosas el artículo 4.6 de la CEAL prescribe que las enti dades locales deben ser consultadas, en la medida de lo posible, a su debido tiempo y de forma apropiada, a lo largo de los procesos de planificación y de decisión para todas las cuestiones que les afectan directamente. La autonomía local española tampoco sale bien parada desde esta perspectiva. En concreto, en cuanto a las relaciones entre comunidades autónomas y colectividades locales, la Recomendación del Congreso de los Poderes Locales y Regionales de Europa, de 14 de noviembre de 2002 ha apuntado lo siguiente:

"1. Estima que por su parte las comunidades autónomas parecen dar poca importancia a las relaciones directas, en cada región, con las colectividades 
locales y, sobre todo, a la creación de organismos de participación de las colectividades locales en las decisiones de las comunidades autónomas correspondientes.

2. Observa con sorpresa que la poca atención dedicada a la cuestión de la aproxi mación entre comunidades autónomas y colectividades parece contrastar con los fuertes poderes de las regiones en materia de reglamentación de las colectividades locales.

3. Considera que el futuro reserva ocasiones cada vez mayores de concertación de políticas y de acciones administrativas que se tratarán de definir por medio de procedimientos adecuados con el fin, precisamente, de garantizar que en esta colaboración ca da una de las partes tenga plena autonomía de decisión."

Respecto a los recursos financieros de las entidades locales, el artículo 9.1 de la CEAL dispone que "las entidades locales tienen derecho, en el marco de la política económica nacional, a tener recursos propios suficientes de los cuales pueden dis poner libremente en el ejercicio de sus competencias".

Es verdad que el artículo 142 de la Constitución española consagra el principio de suficiencia financiera de nuestras entidades locales y que las competencias sólo pueden ejercerse con un volumen de recursos financieros paralelo a la importancia de aquellas, pero es más cierto que la libre disponibilidad de estos recursos no se encuentra proclamada de forma expresa en nuestro ordenamiento jurídico interno y que en la práctica las administraciones supralocales utilizan la técnica de la subvención condicionada para eludir la financiación incondicionada a la que las entidades locales tienen derecho.

En relación a la protección legal de la autonomía local, el Congreso de los Poderes Locales y Regionales de Europa, en su Recomendación núm. 121, de 14 de noviembre de 2002, sobre la democracia local y regional en España, después de congratularse de la introducción en la Ley Orgánica del Tribunal Constitucional del conflicto de defensa para la autonomía local (parágrafo 32) observa, sin embargo, a este respecto que las limitaciones de legitimación previstas por la legislación pueden hacer que el cumplimiento del requisito de al canzar, a escala nacional, un número de municipios superior al millar sea particular mente complejo (parágrafo 33).

Los datos comparados, hechos públicos en la memoria del Tribunal Constitucional español correspondientes al año 2003, indican que el en período 1999-2003 tan sólo se interpusieron 8 conflictos en defensa de la autonomía local. Se ha de tener en cuenta que, en idéntico período, se interpu- 
sieron ante el Tribunal Constitucional 181 recursos de inconstitucionalidad, 418 cuestiones de inconstitucionalidad, 34.136 recursos de amparo y 74 conflictos positivos de competencia.

\section{Propuestas}

Una vez analizados los principales problemas que presenta nuestro régimen local en relación con el acervo europeo en el que debe inspirarse, la Comisión se encuentra en condiciones para proponer algunas medidas concretas tendentes a solucionar los problemas detectados.

Primera.- Introducir en la nueva Ley básica sobre el gobierno local los preceptos de la CEAL -como los artículos 3.1, 4 apartados 3 a 6, 9, etc.) que no están incorporados en la actual Ley 7/1985, de 2 de abril, reguladora de las Bases del Régimen Local. Con esta técnica se pretende elevar el contenido de dichos preceptos al denominado bloque de la constitucionalidad, así como fomentar que nuestro ordenamiento jurídico contenga un concepto avanzado de autonomía local que se corresponda con el compromiso asumido por el reino de España ante el Consejo de Europa y los 34 países europeos que, como él, han ratificado la CEAL.

Segunda.-Proteger el debilitado poder normativo de las entidades locales españolas contra el desarrollo excesivo del poder reglamentario estatal y autonómico sobre asuntos de competencia local. En concreto, la medida propone introducir un nuevo precepto en la Ley básica del gobierno local donde se establezca que cuando la ley, estatal o autonómica, atribuya a las entidades locales una competencia con carácter de propia, las normas reglamentarias de desarrollo que aprueben la administración del Estado o la de la Comunidad Autónoma respectiva, de acuerdo con el orden constitucional de distribución de competencias, tendrá carácter supletorio respecto de las ordenanzas o reglamentos que aprueben las entidades locales sobre esa materia.

Esta fórmula permite cohonestar, de forma adecuada, la capacidad normativa del Estado y de las Comunidades autónomas con la capacidad reglamentaria de los entes locales. Además, de esta forma se evitan las temidas lagunas legales y se posibilita que nuestras entidades locales puedan ordenar una parte importante de los asuntos públicos, conforme lo que establece el artículo 3.1 de la CEAL.

Tercera.-Otro de los problemas a solventar en la nueva Ley es cómo conseguir que las competencias que el legislador encomiende a las entidades lo- 
cales sean, normalmente, plenas y completas, tal y como se contempla en el artículo 4.4 de la CEAL. A juicio de la Comisión el legislador estatal puede, en parte solucionar este problema puesto que se encuentra facultado para modificar la actual redacción del artículo 2.1 de la LRBRL, introduciendo una redacción más ajustada a la CEAL.

El precepto de la nueva Ley podría indicar que para la efectividad de la autonomía garantizada constitucionalmente a las entidades locales, la legislación del Estado y la de las comunidades autónomas, reguladora de los distintos sectores de acción pública, según la distribución constitucional de competencias, debe asegurar a los municipios, las provincias y las islas su derecho a ordenar, gestionar y resolver una parte importante de los asuntos públicos, en el marco de la ley, bajo su propia responsabilidad y en beneficio de sus habitantes. A tal fin, dicha legislación debe atribuirles las competencias plenas y completas, que procedan, de conformidad con los principios de descentralización y de máxima proximidad de la gestión y prestación de servicios a los ciudadanos. La atribución de una competencia a otra autoridad debe motivar la decisión adoptada en el propio preámbulo del texto legal, sobre la base de la amplitud o la naturaleza de la tarea a realizar o las necesidades de eficacia o economía.

La existencia de una norma de esas características es más respetuosa con la autonomía local constitucionalmente garantizada que el artículo 2.1 de la LRBRL vigente en la actualidad.

Cuarta.- En ese mismo orden de cosas, la Comisión recomienda diseñar un mejor sistema de delimitación de las competencias municipales propias, donde se especifique claramente, de acuerdo con su capacidad, las responsabilidades, de ordenación y gestión, que se atribuyen a los mismos. Dicho de otra manera, la nueva Ley debe especificar qué parte de la materia de protección civil, de los servicios sociales o de la protección del medio ambiente pongamos por caso, deben ser competencia propia de los municipios, lo que no obsta para que el ejercicio de dichas competencias se sujete a las previsiones contenidas en la ley sectorial reguladora de la materia, cuando esta exista.

Quinta.-También se considera conveniente que el diferente régimen competencial de los municipios se cohoneste con un sistema diverso de organización de los municipios, de mayor a menor complejidad, y con un sistema de financiación que permita visualizar el principio de conexión entre las competencias a ejercer y los recursos transferidos. 
Sexta.- Desde esta misma perspectiva, en el momento de elaborar el nuevo listado de competencias propias de los municipios el legislador básico debería respetar los principios y directrices contenidos en los parágrafos anteriores. En este sentido, la Comisión propone traspasar lo que deben ser competencias propias de los municipios, como por ejemplo la ordenación, gestión, ejecución y disciplina urbanística que contiene el artículo 25.2, o la ordenación, control y disciplina de las actividades de los ciudadanos a que hace mención el artículo 84 de la LRBRL al nuevo listado de competencias locales, listado que lógicamente debe ser ampliado con los denominados servicios impropios y aquellas nuevas competencias que el legislador le atribuya atendiendo al principio de proximidad.

Séptima.-Las competencias que la nueva Ley básica atribuya a los municipios que no sean capaces de ejercitar algunos de los municipios medianos o pequeños, por falta de capacidad administrativa o de gestión, deben ser ejercidas por las diputaciones provinciales o por las otras Corporaciones de carácter representativo a que hace mención el artículo $141.1 \mathrm{CE}$, por ser la provincia una entidad local de proximidad y porque sus órganos de gobierno están formados por concejales escogidos en función de los resultados electorales de las elecciones municipales.

Octava.-En este sentido la Comisión considera valioso que la futura regulación legal mantenga como objetivo que la defensa y gestión de los intereses locales permanezca en la esfera local, puesto que está de acuerdo con la tesis, explicitada en el preámbulo de la CEAL, que sostiene que el derecho de los ciudadanos a participar en la gestión de los asuntos públicos puede ser ejercido más directamente en el nivel local y que afirma que la existencia de gobiernos locales, investidos de competencias efectivas, permite una administración eficaz y próxima al ciudadano.

Dicho de otra manera, la Comisión considera que cuando una materia afecta directa o primordialmente al círculo de intereses municipales o puede ejercerse mejor desde la proximidad, se debe atribuir al mundo local, principalmente al ayuntamiento, y cuando su capacidad de gestión no lo permita o el servicio requiera una prestación a mayor escala a los entes locales intermedios, porque así lo requiere el principio democrático combinado con el principio de proximidad: los poderes locales gestionan y resuelven los problemas de índole local.

Entre los asuntos de interés municipal y los asuntos de interés autonómico hay asuntos intermunicipales que no pueden ser desempeñados de forma 
aislada por los municipios (transporte público comarcal, carreteras y caminos comarcales, planeamiento plurimunicipal, etc.) pero que tampoco presentan un interés intrínseco autonómico, cuya competencia debería ser ejercida por las diputaciones provinciales u otros entes locales intermedios.

Novena.-Por otro lado ya hemos visto en su momento la conveniencia de que Estado y Comunidades Autónomas consulten a las entidades locales, a su debido tiempo y de forma apropiada, a lo largo de los procesos de planificación y decisión para todas las cuestiones que les afectan directamente.

La Comisión propone que se introduzca un precepto de redacción similar al artículo 4.6 de la CEAL en la nueva Ley Básica de Gobierno y Administración Local, al tiempo que sugiere que las referidas consultas se realicen con los Consejos de los Gobiernos locales, de ámbito estatal o autonómicos, formados exclusivamente por miembros de los gobiernos locales. Ello sin perjuicio del mantenimiento de las comisiones mixtas actualmente existentes que operarían como foros de discusión y encuentro entre cada uno de los niveles de gobierno respectivo.

Décima.- Por otro lado, la CEAL ofrece un marco adecuado para la regulación de aspectos esenciales del estatuto de los electos locales, que conducen a la superación de ciertos déficits del actual modelo español. Así, a título de ejemplo destacado, es sabido que la normativa española no concede cobertura de paro a los representantes locales en caso que no vuelvan a salir elegidos, lo que parece contrario a la finalidad perseguida por el artículo 7.2 de la CEAL.

No debe extrañarnos, pues, que el CPLRE en su recomendación 121 considere que "una situación como esta no puede más que desfavorecer un cierto número de categorías profesionales manteniéndolas al margen de las funciones electivas públi cas en el ámbito local'. A juicio de la Comisión, la nueva Ley Básica debería solucionar este problema, que está íntimamente relacionado con el derecho fundamental al acceso en condiciones de igualdad a los cargos públicos a que hace mención el artículo 23 de la CE y con la obligada remoción, por los poderes públicos, de los obstáculos existentes para facilitar la participación de todos los ciudadanos en la vida política (art. 9.2 CE).

La Comisión cree que la adopción conjunta de las dos medidas mencionadas no supone introducir privilegio alguno en favor de los miembros de las entidades locales, puesto que es claro que las relaciones de las autoridades y 
funcionarios con la ciudadanía son mucho más intensas y afectan mucho más a la vida cotidiana de los ciudadanos que las relaciones que se conciertan de forma voluntaria, con empresas y particulares, en las que el riesgo de que se produzcan situaciones de conflicto es mucho menor. Por ello, parece conveniente la adopción de las medidas propuestas en aras a impedir, o al menos obstaculizar, el uso abusivo de la acción penal contra miembros de las entidades locales por motivos espurios o para obtener más fácilmente una indemnización.

Undécima.-Respecto a los cauces de defensa de la autonomía local llama la atención las dificultades legales con que se encuentran las entidades locales españolas para interponer el recurso para la defensa de la autonomía local, lo que ha llevado a que desde su implantación hasta el año 2003 tan sólo se hayan podido interponer ocho recursos de este tipo.

Ciertamente las limitaciones impuestas en el artículo 75 ter. de la Ley Orgánica 2/1979, de 3 de octubre, del Tribunal Constitucional (en adelante LOTC), para interponer el conflicto de defensa en la autonomía local son excesivas y así lo atestiguan las estadísticas del alto Tribunal. Para superar la rígida restricción actual la Comisión considera que lo ideal sería que todos los municipios y provincias españolas estuvieran legitimados para interponer, de forma individual, el conflicto en defensa de la autonomía local.

En relación a las provincias, su número relativamente reducido hace posible implementar la medida propuesta sin mayores complicaciones en el nivel autonómico, pero respecto de los municipios al existir más de ocho mil municipios en España se plantean dudas sobre si la adopción de la medida propuesta podría colapsar, más de lo que ya lo está, nuestro Tribunal Constitucional.

Por todo ello la Comisión propone la reducción de los quórum de legitimación para la interposición del conflicto en defensa de la autonomía local tanto en el caso de las provincias como en el de los municipios. La fijación de quórum razonables permitiría garantizar la defensa de la autonomía local al tiempo que actuaría como factor de objetivación relativa de la interposición de los conflictos en defensa de la autonomía local. Además, se propone añadir un nuevo apartado d) al mencionado artículo 75 ter. de la LOTC, que complementando la previsión anterior, legitimara a la asociación de entidades locales con mayor implantación en el ámbito territorial de aplicación de la disposición cuestionada para la interposición directa del conflicto en defensa de la autonomía local. 
Desde esa misma perspectiva se aconseja modificar el contenido de los actuales artículos 34.1 y 37.2 de la LOTC en el sentido de citar y permitir la personación de la asociación de entidades locales con mayor implantación en el ámbito territorial de la disposición impugnada en aquellos recursos de inconstitucionalidad o cuestiones de inconstitucionalidad en las que se enjuicie la constitucionalidad de ley o disposición normativa con fuerza de ley que afecte directamente a la administración local. A juicio de la Comisión no tiene sentido que en los procesos constitucionales que afectan directamente a la administración local no se permita la personación de los legítimos representantes de ese nivel de gobierno.

Para facilitar la citación al Tribunal Constitucional, esta reforma debería ir acompañada de una medida complementaria consistente en que el MAP publicase en el Boletín Oficial del Estado, con periodicidad adecuada, el nombre y la dirección de las asociaciones de entidades locales con mayor implantación en el ámbito territorial nacional y en el ámbito territorial propio de las diferentes comunidades autónomas, lo que requiere la formación de un registro estatal específico para dichas asociaciones.

\section{LAS COMPETENCIAS Y SERVICIOS LOCALES}

\section{Estado de la cuestión}

Las competencias locales son consideradas por la Comisión como el elemento central del Libro Blanco, y de la problemática de los gobiernos locales.

En España, la LRBRL construyó el principio de autonomía local con el propósito principal de que los entes locales no estuviesen sometidos a controles genéricos por parte de otros niveles de gobierno, rompiendo así una prolongada inercia histórica. Pero un principio de autonomía local centrado casi exclusivamente en esa cuestión formal de la exclusión de los controles administrativos resulta notoriamente insuficiente, tanto desde el punto de vista formal como desde el de la necesaria capacidad de acción que deben tener los gobiernos locales para gestionar efectivamente los intereses de sus colectividades.

Porque precisamente para la gestión de sus respectivos intereses es para lo que está prevista la autonomía de que gozan los municipios, provincias y comunidades autónomas en la Constitución de 1978 (art. 137). La autonomía local no puede ser, por lo tanto, una cualidad abstracta, en el vacío, sino que debe asociarse indeleblemente a la gestión de intereses del ente del cual se predica. Y puesto que no cabe hablar de gestión de intereses sin que se os- 
tenten las competencias necesarias para ello, la Comisión entiende que la autonomía local proclamada en nuestra Constitución presupone un contenido competencial sobre el que proyectarse.

El modelo de competencias locales vigente en España se ha mostrado insuficiente para satisfacer un mínimo razonable de expectativas: el sector local sigue anclado en la gestión de apenas el $15 \%$ del gasto público. En los últimos años se ha debatido intensamente acerca de que el reparto porcentual entre niveles de gobierno fuese distinto: tal vez un 50-25-25, un 40-30-30, o un 40-3525. La Comisión no pretende concretar cuál debe ser el porcentaje exacto, pues sobre esta cuestión cabrían muchos matices, pero si parece indiscutible que la cantidad de recursos en manos locales son insuficientes y desde hace muchos años no ha experimentado aumento alguno. Ello es indicativo de que el gasto público no ha sido objeto de descentralización a los municipios de modo paralelo a las demandas que la sociedad plantea a sus ayuntamientos.

En aras de ese objetivo de descentralización se inició un proceso de elaboración de Pactos Locales en las Comunidades Autónomas que han tenido un desigual avance. En la mayoría de ellas se han creado mecanismos de colaboración interadministrativa (como comisiones y órganos de carácter paritario) integrados por representantes autonómicos y miembros de las diferentes asociaciones de las Entidades locales, con objeto de poner en marcha la llamada segunda descentralización y estudiar de manera pormenorizada los aspectos que confluyen en el mismo, en cuanto a las competencias susceptibles de descentralización y los consiguientes problemas jurídicos, económicos y de gestión que pueden derivarse del mismo. Algunas Comunidades Autónomas cuentan ya en su legislación con normas que delimitan el marco de actuación de los gobiernos locales dentro de la respectiva Comunidad Autónoma, suponiendo en muchos casos el instrumento facilitador de ese proceso de descentralización. En otras, este desarrollo legislativo se encuentra en fase avanzada de culminación. Los instrumentos específicos previstos en la mayor parte de los casos se concretan en la transferencia de competencias mediante ley, la delegación y la encomienda de gestión, a través del otorgamiento de convenios.

En la misma línea de arquitectura para seguir construyendo el modelo territorial a la Comisión le merecen una valoración positiva las propuestas actuales para incluir en la reforma de los Estatutos autonómicos una serie de normas que refuercen los distintos aspectos que conforman la autonomía local, entre ellos, el competencial. Se produciría así también una elevación de rango, dado que los Estatutos son leyes orgánicas. Esta elevación de rango ha 
sido muy demandada, entre otros, por el informe de expertos del Consejo de Europa sobre el Borrador de este Libro Blanco. La LRBRL pretendía cumplir una función constitucional: integrar el bloque de constitucionalidad y condicionar al legislador sectorial, pero teniendo en cuenta que la propia LRBRL es ley ordinaria, sus efectos en este sentido han sido escasos. Por lo tanto, la inclusión de tales normas en los Estatutos autonómicos si conseguirían el mejor efecto garantizador de la autonomía local al integrar plenamente el bloque de constitucionalidad.

La regulación vigente de las competencias locales presenta una serie de características que deben ser presentadas, siquiera sea como una somera exposición del estado de la cuestión que es considerada central por gran parte de los actores del mundo local. Posiblemente el esquema competencial diseñado por la LRBRL de 1985 no fuese desacertado, aunque el desarrollo posterior de los acontecimientos sí ha demostrado que el sistema previsto no es suficiente para dotar a los gobiernos locales de un núcleo competencial propio y coherente con una autonomía local de carácter político. Así, los rasgos que debemos resaltar en el modelo vigente son los siguientes:

\subsection{Ausencia de un listado de competencias locales y remisión al legislador sectorial}

La legislación básica de régimen local no ofrece una lista determinada y formal de competencias locales, efectuando una remisión a las leyes sectoriales estatales y autonómicas, que serán las llamadas a atribuir competencias, limitándose la ley básica a establecer una serie de materias de interés local (art. 25).

Esa remisión no ha obtenido un resultado satisfactorio por varias razones. En primer lugar, porque en algunas ocasiones las leyes sectoriales ni siquiera han atribuido competencias a los gobiernos locales o han devuelto la remisión a lo que disponga la legislación sobre régimen local, efectuando así lo que ha sido calificado como remisión diabólica en la que resultan olvidados los gobiernos locales. Pero es fácilmente constatable que cuando las competencias han sido reconocidas, el contenido atribuido dista mucho de llenar la expectativa de la autonomía local.

En efecto, en algunas ocasiones no se atribuyeron competencias como propias de los gobiernos locales, sino de forma delegada. Aunque en puridad jurídica podamos considerar que las atribuidas por delegación son también competencias locales, debemos pronunciarnos a favor de que el mayor núcleo competencial local esté integrado por competencias propias, porque ello concuerda mejor con la autonomía política que corresponde a los gobiernos locales. 
Existen otros casos en los que el contenido atribuido no pasa de meras facultades gestoras, sin una relevancia que permita hablar de auténticas competencias. Es decir, no se atribuye un verdadero campo competencial que permita a los gobiernos locales desarrollar las políticas públicas que bajo su propia responsabilidad decidan implementar en su territorio.

En numerosas ocasiones las leyes sectoriales incrementan las obligaciones, las responsabilidades o las cargas municipales. En estos casos se da una situación lesiva para la autonomía local, especialmente si la ley que atribuye la obligación o la carga no pone a disposición de los ayuntamientos los recursos necesarios para cumplirla (podríamos aquí citar numerosos ejemplos como la legislación relativa a protección civil, patrimonio histórico, residuos o medio ambiente).

Incluso podemos encontrar ejemplos en los cuales, en virtud de un convenio administrativo prorrogado repetidamente, los gobiernos locales desarrollan una actividad bajo una serie de duras condiciones y a cambio de una aportación económica. El hecho de desarrollar la actividad en virtud de convenios administrativos durante varios años denota que la competencia debería ser local, y deben ser atribuidos los recursos necesarios para su ejercicio.

Por último, es fácil apreciar que en muchos casos el legislador sectorial ha considerado suficiente la creación de órganos colegiados en los que participan representantes locales o incluso la concesión de trámite de audiencia a los gobiernos locales. Se trata normalmente de órganos mixtos, con funciones consultivas, asesoras o de participación, que pueden ser valorados positivamente desde el punto de vista del funcionamiento normal de las relaciones interadministrativas, y puede ser una buena vía para que los representantes de los entes locales puedan participar en procesos de toma de decisiones estatales o autonómicas. Pero debemos tener claro que la participación en órganos de este tipo no compensa el déficit de competencias locales. O dicho de otro modo, la falta de competencia no se suple mediante un sistema de relaciones intergubernamentales.

En detrimento también de la autonomía local, el legislador sectorial ha impuesto una serie de controles, tutelas o medidas de coordinación excesivas (hay también múltiples ejemplos, como trámites de aprobación final en materia de urbanismos, protección civil, subordinación de decisiones municipales a informes vinculantes, autorizaciones preceptivas para la enajenación de patrimonio, etc.). Muchas de estas normas han hecho un uso exagerado del interés general, sin que en absoluto se haya justificado suficientemente la con- 
currencia de intereses supralocales (muestras de ello pueden ser la Ley 27/1992, de 24 de noviembre, de Puertos del Estado y de la Marina Mercante, o la Ley 13/1996, de 30 de diciembre, en lo relativo a las obras realizadas en el ámbito del aeropuerto y su zona de servicio). En el ámbito de la legislación autonómica también se han producido estas situaciones y las diversas leyes sectoriales (sobre puertos o red ferroviaria, por ejemplo) suelen establecer, respecto de sus obras de interés general, la exención de la exigencia de la preceptiva licencia municipal, dando participación mediante un informe municipal o incluso no concretando suficientemente el mecanismo de intervención municipal. Y también se ha producido un desplazamiento de las normas sobre colaboración y coordinación previstas en la LRBRL (por ejemplo, en las disposiciones adicionales segunda y tercera de la Ley 13/2003, de 23 de mayo, reguladora del contrato de concesión de obra pública), a favor de otras normas específicas y menos respetuosas de la autonomía local.

\subsection{Los servicios minimos y las actividades o servicios esenciales.}

Por otro lado, la LRBRL estableció una serie de servicios de prestación obligatoria en función de la población de cada municipio (art. 26). A pesar de estar configurados más como una obligación municipal a favor del ciudadano, tampoco puede negarse que se han contemplado en la práctica como un ámbito de competencia local. No pretendemos aquí hacer un análisis jurídico profundo sobre esta cuestión, pero consideramos de interés resaltar que la atribución a los municipios de la obligación de prestar tales servicios no incluía claramente potestades de regulación o de intervención, sino únicamente la mera gestión. Debemos decir también que veinte años después, la lista de servicios necesita una actualización: en unos casos por desuso de algunos servicios o porque ha habido un desplazamiento de la prestación a otras entidades (efectivamente hoy ya se aprecia un cierto anacronismo en servicios como suministro de gas y calefacción, mataderos, etc.), y en otros por la liberalización de algunos otros servicios (como mataderos o servicios funerarios).

De forma parecida a lo que sucede con los servicios municipales mínimos, la figura de las actividades o servicios esenciales reservados a los entes locales recogida en el artículo 86.3 de la LRBRL no tiene por finalidad la definición o determinación de competencias, por lo que son reproducibles la práctica totalidad de reparos señalados en el párrafo anterior.

Habitualmente se ha entendido que la obligación municipal de prestación de estos servicios se refiere a su mero establecimiento, sin incluir clara- 
mente potestades de regulación o de intervención. Sin embargo, la Comisión considera que el principio de autonomía local exige que se proyecte sobre estos servicios públicos no sólo la gestión sino también las potestades de planificación, programación y regulación de los mismos.

Por todo ello, la Comisión concluye que si bien la institución de los servicios municipales mínimos ha tenido algún efecto de proteger las competencias municipales, su eficacia en este campo es muy limitada; y en todo caso sólo ha podido alcanzar a asegurar actuaciones de mera gestión, siendo necesario que las potestades municipales respecto a sus servicios públicos sean de mayor relevancia.

\subsection{La capacidad general de iniciativa y de prestación de servicios complementarios}

El reconocimiento de esta capacidad en los artículos 25.1 y 28 LRBRL abre interesantes expectativas de flexibilidad en la asunción de competencias municipales, al habilitar a los ayuntamientos para intervenir ante nuevas demandas ciudadanas o sociales no previstas por el legislador y no cubiertas por la acción de las demás administraciones públicas. Sin embargo, este potencial queda lastrado por la deficiente regulación de las potestades que podrán ejercer los municipios para desarrollarlos. Así, sucede con frecuencia que se interpreta de manera restrictiva el principio de reserva de ley en materia sancionadora, fiscal o simplemente de limitación de las actividades privadas, y se restringe también el ámbito de regulación autónoma de los reglamentos y ordenanzas municipales. El resultado es que, al fin y al cabo, lo que pueden hacer los municipios al amparo de los artículos mencionados es poco más que actividades de naturaleza similar a las privadas, con escaso o nulo contenido público o administrativo.

La Comisión considera que una mejor regulación de las potestades administrativas que la Ley atribuye a los municipios, puestas en conexión con sus competencias, permitiría una mayor eficacia de los vigentes artículos 25.1 y 28 LRBRL y daría más opciones a los ayuntamientos para afrontar la intervención pública en los nuevos ámbitos de actuación pública que demanda la sociedad.

\subsection{Ausencia de medios adecuados de defensa de las competencias locales}

A la vista de la situación descrita, es fácil entender que las Entidades locales no han dispuesto de medios adecuados para defender su falta de competencias. En primer lugar, porque dado que el contenido competencial con- 
creto debía venir atribuido por la legislación sectorial, resulta imposible la reclamación jurisdiccional de la inactividad o la omisión del legislador cuando no atribuye competencias a los gobiernos locales. En segundo lugar, porque los principios a que debe sujetarse el legislador sectorial en la atribución de competencias a los gobiernos locales son tan escasos que resulta muy difícil acreditar que las leyes sectoriales, por poco satisfactorias que sean, menoscaban la autonomía local garantizada por la LRBRL. Y en tercer lugar, aunque no es menor su importancia, las condiciones para el acceso de las Entidades locales al Tribunal Constitucional son muy restrictivas, como se ha puesto de manifiesto en este Libro.

\subsection{Las limitaciones de la potestad normativa local.}

La expresión más plena de la naturaleza política de los gobiernos locales es su potestad normativa, que se manifiesta en las ordenanzas y reglamentos. Esta potestad, en función del alcance que se le reconozca, puede jugar un papel muy importante en la determinación del contenido de las competencias municipales.

Si bien alguna jurisprudencia ha reconocido un ámbito relativamente extenso para esta potestad normativa local, incluso más extenso que el que pueda corresponder a los reglamentos estatales o autonómicos, en atención al hecho de que los gobiernos locales incorporan una función representativa directa que no tienen las demás administraciones públicas, tal como ha señalado incluso el Tribunal Constitucional, en la práctica esta potencial mayor capacidad normativa de las ordenanzas y reglamentos locales queda muy limitada debido a la amplitud que tiene en nuestro ordenamiento jurídico el principio de reserva de ley en materia sancionadora y en otros ámbitos normativos que afectan a los contenidos o el ejercicio de los derechos y libertades de los ciudadanos. Esto significa que las ordenanzas y reglamentos locales, si van más allá de la regulación de cuestiones de organización o de procedimiento y afectan derechos y libertades de los ciudadanos, necesitan a menudo una habilitación legal más específica que la proporcionada genéricamente por la legislación de régimen local, habilitación que debería serles facilitada por la legislación sectorial (lo cual sucede en pocas ocasiones).

\subsection{Ausencia del principio de suficiencia financiera.}

Anteriormente hemos expuesto que el porcentaje de gasto público que gestionan los gobiernos locales es, seguramente, insuficiente al ser puesto en relación con las actividades que desarrollan (ya se trate competencias formal- 
mente atribuidas o no). Es generalizada la demanda de mayores recursos para las haciendas locales y la denuncia de que la efectiva participación en los tributos de las comunidades autónomas no existe o ha sido sustituida por subvenciones graciables en su concesión, condicionadas en su destino y no garantizadoras de la continuidad y regularidad de la prestación de los servicios públicos subvencionados. Ello incide de forma negativa en la suficiencia financiera de los gobiernos locales y en su potestad de planificación.

La Comisión considera que la suficiencia financiera de los gobiernos locales enmarca las posibilidades reales de la autonomía local, pues, sin medios económicos suficientes, el principio de autonomía local no pasa de ser una mera declaración formal, y que la sustitución de la preceptiva participación en los tributos del Estado y en los de las comunidades autónomas por subvenciones a obras, servicios o actividades municipales supone una clara intromisión de dichos niveles de gobierno sobre los gobiernos locales, privándolos de su potestad decisoria fundamental sin la que no cabe hablar de autonomía local.

\section{Criterios que deben orientar la regulación del sistema de competencias lo- cales}

\subsection{Principios básicos}

Tal y como se ha expresado, el principio de autonomía no ha bastado para atribuir a los entes locales un contenido competencial determinado, haciéndose necesario incorporar formalmente a nuestro ordenamiento jurídico el principio de subsidiariedad, ampliamente desarrollado en los últimos años en el marco del Derecho Comunitario Europeo, al objeto de delimitar y fortalecer las competencias locales, así como adecuarlas de forma flexible a la diversidad de entidades que componen el nivel de gobierno local.

La subsidiariedad, según el Derecho Comunitario Europeo, presenta una doble dimensión, al introducir los criterios de proximidaden la atribución de las competencias y de eficacia en la distribución de las competencias públicas. A ello hay que añadir que la subsidiariedad trae implícito un criterio de intensidad en la intervención, acorde con el principio de proporcionalidad, que puede ser muy relevante al determinar la intervención que corresponda a cada una de las administraciones implicadas en los casos de concurrencia o de competencias compartidas.

La capacidad de gestión para el ejercicio de una competencia no puede implicar un debilitamiento de la autonomía local, por lo que es necesario ase- 
gurar que exista previsión legal para que, en los casos que proceda, otro nivel territorial de gobierno la pueda ejercer subsidiariamente. Es precisamente la relación entre la capacidad de gestión y la vulnerabilidad de la autonomía local lo que obliga a analizar tanto la posición como las funciones de los entes intermedios y la necesidad de definir el ámbito de la intermunicipalidad.

Así pues, el principio de subsidiariedad, en su doble vertiente de proximidad y de eficacia, así como los criterios de flexibilidad en la atribución de las competencias municipales, deberían ser formalmente asumidos y mínimamente desarrollados por la legislación básica de régimen local, lo que no supondría, ni mucho menos, desconocer la función propia de las leyes sectoriales en la atribución de competencias municipales, sino que evitaría mantener la situación actual, en que se remite por defecto a estas leyes para que determinen discrecionalmente las competencias municipales, cuya integridad queda así muy mermada, como ya hemos visto.

Las leyes sectoriales deberían centrarse sólo en regular los aspectos sustantivos propios de la acción pública en el ámbito de que se trate, así como en identificar los aspectos que inciden en un ámbito de interés supralocal, que son los que pueden justificar la atribución de competencias a las administraciones de ámbito supralocal en relación con los mismos.

Los principales criterios para una atribución flexible de competencias deben estar previstos y desarrollados por la legislación básica de régimen local y las leyes sectoriales deben poder concretar su aplicación en cada caso.

Partiendo de la base de que la atribución de las competencias locales debe ser una operación compartida entre diversos tipos de leyes (Ley básica de régimen local, Estatutos de Autonomía, leyes autonómicas de régimen local y leyes sectoriales estatales o autonómicas), corresponde a la Ley básica de régimen local la determinación de los principios y criterios básicos que deben regir el modelo competencial, la definición de las potestades que los municipios podrán aplicar al ejercicio de sus competencias, la garantía de un mínimo de competencias común a todos los municipios del Estado, la determinación mínima de los ámbitos de interés local y la fijación, también a nivel de mínimos, de los servicios cuyo que constituye una responsabilidad de las administraciones locales.

De acuerdo con este criterio, el régimen de competencias municipales de la Ley básica de régimen local debe sustentarse en los siguientes principios: 


\section{a) Autonomía.}

La Ley básica debería desarrollar este principio esencial del régimen local español de forma clara, completa y sistemática, incluyendo sus consecuencias de orden competencial.

\section{b) Naturaleza política del gobierno local.}

Como ya se afirmaba anteriormente, hemos de partir del hecho de que la autonomía local es autonomía política, con capacidad para ordenar y gestionar bajo la propia responsabilidad una parte sustancial de los asuntos públicos mediante el impulso de políticas propias.

En consecuencia, las competencias locales no deben limitarse al plano de la mera gestión de servicios y de funciones burocráticas, sino que deben comprender también potestades normativas, reguladoras, fiscales y de planificación, sin las cuales difícilmente podrían plantearse responsabilidades de auténtico gobierno político de los pueblos y las ciudades.

\section{c) Subsidiariedad.}

La legislación básica de régimen local, en la medida que son los municipios las entidades que más se pueden beneficiar de la aplicación de este principio en su ordenamiento interno, debe establecer los trazos básicos de su contenido y su operatividad, en conexión con el principio de proximidad establecido en el artículo 4.3 de la CEAL.

\section{d) Diversidad, flexibilidad y supletoriedad.}

Si tenemos en cuenta la gran diversidad existente entre la capacidad de unos y otros municipios, debemos asumir que esta diversidad ha de ser también un aspecto básico, y no una mera cuestión incidental como hasta ahora, en la atribución de las competencias municipales. Asimismo, y tal como ha quedado expuesto en apartados anteriores, la diversidad y flexibilidad en la atribución de competencias a los municipios es un requisito esencial para la correcta aplicación del principio de subsidiariedad, en su doble vertiente de proximidad y eficacia, que reclama la atribución de las competencias públicas a la instancia administrativa más próxima a los ciudadanos, siempre que sea capaz de gestionarlas con eficacia. Además, puesto que existe una gran diversidad en la capacidad de gestión de unos y otros municipios, la Ley debe permitir que cada uno de ellos pueda asumir el mayor ámbito de competencias 
que pueda ejercer con eficacia e identificar el nivel territorial de gobierno que se responsabilizaran del ejercicio de las competencias locales no asumidas por determinados ayuntamientos, en el ámbito territorial de los mismos.

\section{e) Principio de proporcionalidad.}

El principio de proporcionalidad como instrumento de control competencial goza de una acrisolada tradición en el Derecho comparado. Por ello, la asunción del principio de proporcionalidad en la futura Ley de Bases, lejos de valorarse como una "singularidad", no supondría sino sumarse a la línea en la que se está avanzando en el marco europeo. Habida cuenta de que se configura como un mecanismo de control que opera tras la utilización del principio de subsidiariedad, convendría que su recepción se produjera inmediatamente después de la mención de éste, previendo que, en el supuesto de que deba tener lugar, la intervención estatal o autonómica habrá de ser la estrictamente indispensable para la consecución de los objetivos perseguidos.

\section{f) Cláusula general de competencias.}

Esta cláusula, que desarrolla el principio de subsidiariedad, atribuye a los municipios una especie de capacitación general para actuar en todos los ámbitos no reservados expresamente a otras administraciones, y que no estén expresamente prohibidos por la ley. Se trataría de combinar los actuales artículos 25.1, 28 y disposición transitoria segunda LRBRL, afirmando que corresponde a los municipios el ejercicio de las competencias administrativas que las leyes no atribuyan expresamente a otras administraciones. Este criterio debería completarse con la definición de las potestades, especialmente las normativas, que pueden ejercer los municipios en desarrollo y aplicación del mismo.

\section{g) Garantías de suficiencia financiera para el ejercicio de las competencias.}

Con independencia de que se opte por que el sistema de financiación local no se regule en la Ley de Bases, sino en una ley específica (e, incluso, aun cuando se decidiera que ni siquiera la Ley de Bases debe contener ningún principio o directriz que pudiera condicionar, siquiera mínimamente, el diseño del modelo de financiación), es indudable que sí deben tener cabida en la futura Ley de Bases aquellas medidas de naturaleza financiera destinadas específicamente a salvaguardar el ejercicio verdaderamente autónomo de sus competencias por parte de las entidades locales, como por ejemplo: que las entidades locales deben disponer fundamentalmente de ingresos no afectados; se han de incluir específicas garantías de suficiencia financiera para los 
supuestos de alteración del estatus competencial en sentido ascendente; y una garantía destinada a solventar los problemas que suelen plantearse cuando la competencia normativa y la competencia de gestión residen en niveles de gobierno diferentes, y el que ostenta la primera adopta una medida que supone un gasto para el ente que ha de proceder a su ejecución.

\subsection{Las potestades y las competencias locales}

La legislación de régimen local debe asumir claramente el carácter político del gobierno local y, por tanto, traducirse en la atribución a los municipios de competencias de regulación, gobierno y de gestión de servicios, reconociéndose, así, el liderazgo político derivado de la proximidad al ciudadano.

Todo ello ha de trasladarse a la terminología usada por el legislador y debe comportar un mayor énfasis en la definición de las potestades atribuidas a los municipios, especialmente las de regulación.

En este sentido, sería deseable que la legislación básica de régimen local formulara una regulación mucho más completa de los instrumentos normativos locales (ordenanzas, reglamentos, planes, etc.) que, además de determinar su objeto y procedimiento de elaboración, defina también su alcance, sacando el mayor partido posible a la idea, asumida por alguna sentencia del Tribunal Constitucional, de que las normas locales, al incorporar la representación directa de la sociedad, tienen una mayor capacidad de configuración normativa que los reglamentos estatales o autonómicos (Propuesta de supresión).

En otras palabras: en relación con las materias que integran su ámbito de intereses, incluidas todas las que no hayan sido atribuidas en exclusiva por ley a otra administración pública, los municipios deben poder ejercer potestades plenas de regulación, con el único límite de no vulnerar ámbitos reservados a la ley, ámbitos que, además, deberían ser objeto de interpretación claramente restrictiva. En todo caso, la Ley básica del gobierno local debería establecer que cuando la ley, estatal o autonómica, atribuya a las entidades locales una competencia con carácter de propia, las normas reglamentarias de desarrollo que aprueben la administración del Estado o la de la comunidad autónoma, de acuerdo con el orden constitucional de distribución de competencias, tendrán carácter supletorio respecto de las ordenanzas o reglamentos que aprueben las entidades locales sobre esa materia.

Esta fórmula permite cohonestar, de forma adecuada, la capacidad normativa del Estado y de las comunidades autónomas con la capacidad normati- 
va de los entes locales, a la vez que superar las actuales limitaciones a la autonomía normativa de las colectividades locales españolas puesta de manifiesto por el Congreso de los Poderes Locales y Regionales de Europa en su Recomendación núm. 121, de 14 de noviembre de 2002, sobre la democracia local y regional en España.

\subsection{Las competencias locales se definen en base a potestades públicas.}

Suele definirse la competencia como la medida de potestades que tiene un órgano o un ente. De modo que la determinación de las competencias públicas es una operación que debe manejar dos vectores distintos: el de los asuntos o materias, por una parte, y el de las potestades, por otra.

El debate, mucho más intenso, sobre las competencias estatales y autonómicas nos ha llevado a asumir plenamente este fenómeno. Así, no solemos limitarnos a decir que el Estado o tal o cual comunidad autónoma tienen competencias sobre una u otra materia, sino que acostumbramos a precisar si la competencia disputada es legislativa o ejecutiva,o de legislación básica o plena, o de mera gestión,entre otras diversas posibilidades.

La legislación vigente de régimen local a responder a la realidad de la existencia de gobiernos multinivel. Aunque ya no reproduce el listado de supuestas competencias municipales de la legislación precedente, sino que lo sustituye por uno o más simple de materias o intereses. Así se continúa sin definir las potestades que los municipios podrán ejercer en relación con cada materia, quedando esta operación a la regulación contenida en las leyes sectoriales.

2.4 Materias en que deben atribuirse competencias a los municipios y determinación de los ámbitos de interés local

Como hemos apuntado anteriormente, uno de los aspectos fundamentales del modelo competencial básico de régimen local debe ser el de la determinación de los ámbitos o sectores en los que se considera que hay presencia de intereses locales y, por lo tanto, deben atribuirse competencias a los municipios, bien sea directamente por la propia Ley básica de régimen local, o bien por la legislación sectorial correspondiente, la cual al atribuir competencias deberá respetar los principios que ya también hemos citado.

De esta forma, la Ley básica cumpliría con su función de configurar un contenido mínimo de la autonomía local, pero además ofrecería al legislador 
sectorial una serie de principios generales que pueden producir mejor resultado que la mera remisión existente en la actualidad.

La Ley básica de régimen local debería determinar los sectores de actividad administrativa o ámbitos en los que el legislador constata la presencia de intereses locales. Esa determinación debe hacerse, además, conforme a una serie de criterios:

1.- La lista de sectores o ámbitos de actividad debe ser mucho más amplia y adecuada a la realidad de la sociedad actual; es decir, debe actualizarse y ampliarse la contenida en el vigente art. 25 LRBRL.

2.-Debe tratarse de una lista abierta, en tres sentidos: debe poder ser ampliada por las leyes autonómicas de régimen local; también debe poder ser ampliada por las leyes sectoriales; y los propios municipios interesados deben poder proyectar su interés en otros sectores de actividad administrativa, si así lo requieren los intereses de su respectiva colectividad, siempre que no vulneren las leyes.

3.-Esta lista de sectores y ámbitos de interés local constituye el principal campo de aplicación del principio de subsidiariedad. Sin perjuicio de ello, las leyes sectoriales reguladoras de estos sectores o ámbitos deben reconocer, amparar, potenciar, y en su caso desarrollar, competencias municipales de ordenación y gestión relacionadas con los mismos.

4.- La lista en cuestión debería complementarse con la afirmación expresa de que, más allá de los ámbitos o sectores en los que se proyecta el interés local, nada de lo que interesa o afecta a sus vecinos es ajeno al ayuntamiento, de modo que el municipio tiene también capacidad para asumir, expresar y representar ante las instituciones competentes de cualquier orden las preocupaciones y aspiraciones de su comunidad.

$\mathrm{Al}$ identificar estos sectores debe tenerse en cuenta que la modificación de la LRBRL tiene la voluntad de imprimir un esfuerzo descentralizador a favor de los gobiernos locales.

A continuación, la Comisión considera relevante proponer una serie de materias de interés local en las que los gobiernos locales deben tener competencia. Es preciso aclarar que no todas son propias de una Ley básica de régimen local; sin embargo, por su interés, y porque proceden en buena parte de las aportaciones remitidas a la Comisión, merecen ser reflejadas. Dadas las ca- 
racterísticas de este documento, las expondremos de modo resumido, a pesar de que las aportaciones son muy detalladas; no obstante la Comisión las ha conocido en toda su extensión. Han sido muy numerosas aquellas que insisten en la necesidad de que las competencias estén concretadas en la norma, y en la adecuada financiación de las mismas, aquellas otras que demandan una distinción de las competencias que deban ostentar las entidades locales menores de las de los municipios, o las que reclaman mayores competencias en las materias de turismo y consumo, montes, costas o playas.

\section{Materias en que deben atribuirse competencias:}

\section{- Seguridad ciudadana:}

Se propone como concepto más adecuado que el de "seguridad en los lugares públicos", y debería contemplarse la capacidad de definir y aplicar políticas preventivas en materia de seguridad ciudadana, coordinación de los diversos cuerpos y fuerzas en el municipio, y el ejercicio de funciones de policía judicial por parte de la policía municipal ${ }^{1}$. Los ayuntamientos deberían tener competencias para regular mediante ordenanza las condiciones a cumplir por las actividades organizadas en espacios públicos y locales de pública concurrencia.

Sería interesante el expreso reconocimiento del alcalde como autoridad de seguridad ciudadana y debería permitirse que los ayuntamientos presten el servicio de forma asociada.

\section{- Circulación de vehículos y servicios de movilidad:}

Las ordenanzas municipales deben poder regular la circulación y el estacionamiento de todo tipo de vehículos por las vías de ámbito local del municipio, tengan o no la condición de urbanas, incluida la posibilidad de estable-

\footnotetext{
${ }^{1}$ Así lo propone, por ejemplo, el Ayuntamiento de Madrid en sus aportaciones al borrador de Libro Blanco; la FEMP indica que un precedente de la colaboración con la administración de justicia es la realizada por el arbitraje de consumo a través de las Juntas Arbitrales de las Corporaciones Locales -municipales y provinciales-, y propone que se incida especialmente en temas como la Orden de Protección a Víctimas de Violencia de Género y en los aspectos que contempla la Ley Orgánica de Medidas Integrales para la Protección a las Víctimas de la Violencia de Género. Algunas de estas actuaciones ya vienen siendo desarrolladas por los ayuntamientos, como ha puesto de manifiesto el Gobierno del Principado de Asturias en su documento de aportaciones al borrador de Libro Blanco.
} 
cer todo tipo de medidas restrictivas para garantizar la seguridad, la fluidez del tráfico y el medio ambiente.

Los ayuntamientos deben ostentar asimismo competencias de control y sancionadoras para hacer cumplir la normativa vigente en las vías de carácter local del municipio y para castigar los eventuales infractores, poniéndolos a disposición judicial si procediera.

Lo que denominamos vías de ámbito o carácter local deben ser, además de las urbanas, los caminos rurales, viales de acceso a urbanizaciones o polígonos y, en general, todo tipo de carreteras o caminos para el tránsito interior del municipio. Únicamente deberían quedar fuera de este concepto las carreteras y autopistas cuyo recorrido excede el término de un municipio.

Los municipios también deben tener competencias para establecer, regular y, en su caso, gestionar servicios de transporte de viajeros dentro del término municipal, así como para participar en la planificación, regulación y gestión de estos mismos servicios cuando trascienden su término municipal. Estos servicios pueden ser de autobús, taxi, tranvía, tren o cualquier otro.

También deberían poder regular el transporte y la carga y descarga de mercancías dentro del término municipal, con la finalidad de adoptar medidas que aseguren una mayor fluidez de tránsito.

Una limitación importante en esta materia es la dificultad que tienen los ayuntamientos para aplicar medidas coactivas a vehículos o conductores domiciliados en otros municipios, situación muy frecuente, como es fácil entender dada la movilidad de los vehículos ${ }^{2}$.

\section{- Protección civil y prevención y extinción de incendios:}

Debería reconocerse la competencia municipal para la formulación de planes de protección civil y para la prevención y extinción de incendios, planes que deberán ser coherentes y estar coordinados con los que formulen las administraciones de ámbito supralocal (con audiencia o participación de representantes municipales).

\footnotetext{
${ }^{2}$ También en este caso, algunas de las actuaciones se vienen desarrollando de hecho por los ayuntamientos, y así lo corrobora el Gobierno del Principado de Asturias.
} 
Asimismo, competencia municipal para aprobar ordenanzas que establezcan medidas preventivas, y en su caso reactivas, en relación con incendios, inundaciones u otro tipo de percances o calamidades.

Los municipios también deberían tener competencias para crear y gestionar servicios de bomberos, así como eventuales servicios de protección civil.

El alcalde debe tener capacidad para ordenar la adopción de las medidas extraordinarias que sean necesarias para proteger a la población en caso de incendio o catástrofe, pudiendo movilizar a los vecinos, requisar equipos u ordenar el desalojo de edificios, entre otras.

\section{- Urbanismo y ordenación del territorio y espacios públicos:}

Los ayuntamientos deben tener competencia para formular y aprobar planes urbanísticos e instrumentos de ordenación del territorio, cuyo ámbito territorial no exceda del término municipal. Estos instrumentos de planificación, en la medida en que no afecten a intereses supralocales, deben ser aprobados bajo la exclusiva responsabilidad municipal, debiendo respetar únicamente los instrumentos de planificación de ámbito supralocal.

Establecimiento del principio general según el cual si hay leyes sectoriales que por razones o servicios de interés general (costas, puertos, aeropuertos...) limitan la capacidad de las instituciones urbanísticas en determinadas zonas del territorio, se deban disponer por estas leyes procedimientos de armonización de los intereses locales y del ordenamiento urbanístico con los generales y el ordenamiento sectorial de que se trate, y no la mera y directa prevalencia de este último, salvo cuando deban prevalecer intereses supralocales por no ser compatibles con los locales.

Reconocimiento también de la plena competencia municipal para la formulación, aprobación y ejecución de instrumentos de gestión urbanística, y para adoptar las medidas que procedan para la protección de la legalidad urbanística y para sancionar eventuales infracciones.

Toda actividad, pública o privada, que modifique la configuración del territorio debe estar sujeta a un trámite de control preventivo municipal.

Competencia municipal para promover la formulación de planes urbanísticos o de ordenación del territorio de ámbito supramunicipal y, en todo 
caso, derecho de los representantes municipales a participar o ser escuchados en el proceso de formulación de los mismos.

Competencia de los municipios para disponer o promover la existencia de parques, jardines, vías públicas y demás espacios públicos de ámbito municipal, y para regular su uso y protección y para estar al cuidado del alumbrado, mantenimiento y limpieza de los mismos ${ }^{3}$.

\section{- Vivienda:}

Se debe atribuir competencia a los municipios para desarrollar mediante ordenanza los aspectos constructivos y las condiciones de habitabilidad de las viviendas y para ejercer los tramites correspondientes para garantizar su cumplimiento (tramitación y otorgamiento de la cédula de habitabilidad).

También se les debe atribuir competencias, en el marco del principio de legalidad tributaria, para adoptar mediante ordenanza medidas que penalicen las prácticas especulativas y las viviendas desocupadas y, en general, para promover la existencia de una oferta suficiente de viviendas asequibles.

Asimismo, deben tener competencias para gestionar promociones municipales de vivienda, sea con destino a alquiler o a venta, o para colaborar en promociones públicas o sociales de vivienda protegida.

También se les debe reconocer la competencia para participar en cualquier caso en la adjudicación de viviendas que hayan sido promovidas por otras administraciones públicas en su término municipal.

Los planes de vivienda deberían contener una línea de financiación específica para el fomento de la construcción de viviendas protegidas por parte de los municipios, incluyendo un parque suficiente de viviendas en alquiler ${ }^{4}$.

\footnotetext{
${ }^{3}$ Entre otras, la FEMP propone que una vez aprobados los planes generales de forma definitiva por las comunidades autónomas con sus respectivos informes medioambientales, el resto de los instrumentos de planeamiento sean de competencia municipal; no obstante la aprobación del planeamiento general y del planeamiento de desarrollo debería corresponder a los ayuntamientos con real capacidad de gestión. En este sentido, el informe de los expertos del Consejo de Europa sobre el borrador de Libro Blanco también sugiere que se suprima la aprobación previa de los planes de urbanismo por la comunidad autónoma.

${ }^{4}$ El Gobierno del Principado de Asturias, en su documento de aportaciones al borrador de Libro Blanco considera que estas propuestas relacionadas con vivienda podrían ser delegables a los
} 


\section{- Medio ambiente:}

Los ayuntamientos deben tener competencia para formular y aplicar una política municipal para la protección del medio ambiente y el desarrollo sostenible de la comunidad.

También deben tener competencia para someter a control preventivo municipal todas las actividades que se desarrollen en su término municipal y puedan afectar el medio ambiente y, si procede, para condicionar el inicio o la continuidad de las mismas a la adopción de medidas de protección ambiental.

Asimismo, los municipios deben poder elaborar y aprobar ordenanzas para la protección del medio ambiente y el desarrollo sostenible, con las que concretarán y desarrollarán en su ámbito las normas más generales, y con las que también deben poder adoptar medidas adicionales de protección ambiental a las vigentes con carácter general, con la única condición de asegurar un mayor grado de protección ambiental.

Entre otros, son sectores que en todo caso pueden ser objeto de desarrollo normativo o de otras medidas municipales para la protección del medio ambiente los siguientes: el ahorro energético y de recursos naturales, la protección del paisaje, el ruido y la emisión de gases con efecto invernadero ${ }^{5}$.

\section{- Agua:}

Los ayuntamientos deben tener competencia para regular, además de prestar, los servicios de abastecimiento de agua y también de evacuación do-

\footnotetext{
municipios, manteniendo la prevalencia general en la exclusividad por la comunidad autónoma. Expresa que pueden considerarse competentes para desarrollar por ordenanza: los aspectos constructivos y de habitabilidad, la penalización de las prácticas especulativas, la gestión de promociones municipales de vivienda, la participación en cualquier adjudicación de viviendas, y el fomento de construcción de viviendas protegidas por parte de los municipios. La FEMP formula, entre otras, las siguientes propuestas: la creación de vías de financiación a favor de los ayuntamientos para que éstos puedan ejercer el derecho de tanteo y retracto sobre la vivienda protegida, y la competencia municipal para la definición de las tipologías edificatorias, incluso en el caso de las viviendas con protección pública, así como para la calificación provisional y definitiva en el caso de las viviendas protegidas.

${ }^{5}$ En este ámbito, el Gobierno del Principado de Asturias también considera que las propuestas son susceptibles de atribución o delegación a las entidades locales.
} 
miciliaria de las residuales. También deben poder tomar la iniciativa y, en cualquier caso, participar en el establecimiento de infraestructuras y servicios de captación y transporte de agua potable para su población y de depuración de aguas residuales.

Asimismo, los ayuntamientos deben tener competencia para elaborar y aprobar ordenanzas para la racionalización y ahorro del consumo de agua en su comunidad, o para adoptar medidas extraordinarias de restricción en caso de escasez.

Los ayuntamientos también deben cuidar de la potabilidad y calidad del agua de consumo humano y de la integridad de las redes de conducción del agua $^{6}$.

\section{- Energía:}

Reconocimiento de la capacidad municipal para formular y desarrollar una política propia en materia de energía, con el objetivo de fomentar el uso de energías renovables, minimizar los consumos energéticos y asegurar el acceso efectivo de los vecinos a un suministro energético suficiente y de calidad.

Para la aplicación de esta política municipal de energía, los ayuntamientos deben poder elaborar y aprobar ordenanzas que establezcan o fomenten prácticas de ahorro energético y de producción o consumo de energías limpias, y que aseguren la existencia de redes y de servicios que garanticen el suministro de energía suficiente y de calidad a todos los inmuebles del término municipal.

Con estas mismas finalidades, los municipios deben poder tomar la iniciativa y, en cualquier caso, participar en la formulación de planes y programas de ámbito supramunicipal para la producción y distribución de energía con destino a su población ${ }^{7}$.

\footnotetext{
${ }^{6}$ El Gobierno del Principado de Asturias también expresa que esta materia viene siendo ejercida de hecho por los ayuntamientos, por lo que podría considerarse su atribución o delegación.

${ }^{7}$ El Gobierno asturiano entiende que es irrenunciable la exclusividad autonómica en materia de energía (y recuerda que el propio Estado ha limitado a la comunidad autónoma en esta materia), aunque pueda ser delegable la promoción de prácticas de ahorro energético.
} 


\section{- Telecomunicaciones y sociedad de la información:}

Los ayuntamientos deberían tener reconocida la competencia para regular mediante ordenanza el establecimiento de infraestructuras de telecomunicaciones, ya sea en base al hecho de que transcurren por el dominio público municipal, o por motivos urbanísticos, ambientales o para la protección de la salud pública.

Se debe reconocer a los municipios una mayor capacidad de la que tienen actualmente para obligar a los operadores a compartir infraestructuras de telecomunicaciones; así como competencia para explotar redes o para prestar servicios de telecomunicaciones.

Se debería reconocer también la capacidad municipal para adoptar medidas normativas o de fomento que persigan el objetivo de garantizar el acceso de todos los vecinos a servicios accesibles de telecomunicaciones de banda ancha y, en general, nuevas tecnologías ${ }^{8}$.

\section{- Limpieza y residuos:}

Debería haber competencia municipal no sólo para prestar, sino también para regular el servicio de limpieza de la vía pública y zonas públicas y de recogida, transporte y tratamiento de residuos domésticos.

La competencia municipal en estos asuntos debe permitir a los ayuntamientos la promulgación de ordenanzas que establezcan deberes ciudadanos para el mantenimiento de la limpieza de la vía pública y la minimización y recogida selectiva de los residuos domésticos, incluida la posibilidad de imponer sanciones si se incumplen estas obligaciones.

Los ayuntamientos también deben tener competencias que les permitan participar en la regulación y en la gestión de los residuos no domésticos (industriales, sanitarios, agropecuarios... $)^{9}$.

\footnotetext{
${ }^{8}$ Sobre esta materia, el Gobierno del Principado considera que las competencias deben ser concurrentes y de necesaria colaboración entre la comunidad autónoma y los ayuntamientos.

${ }^{9}$ En esta materia, el Gobierno asturiano considera que son los ayuntamientos quienes vienen actuando de hecho, y serían atribuibles o delegables a las entidades locales.
} 


\section{- Salud pública:}

Debería haber competencia municipal para establecer mediante ordenanza normas tendentes a asegurar la existencia de condiciones óptimas para la salud colectiva, y competencia también para desarrollar las actuaciones necesarias (actos de control preventivo, inspecciones, sanciones, información, servicios técnicos...) para asegurar el cumplimiento de las mismas.

Las competencias municipales en materia de salud pública tienen, entre otros, los objetos siguientes: potabilidad de las aguas, higiene de los alimentos, higiene de las viviendas, prevención de epidemias, educación alimentaria, protección de animales, etc. ${ }^{10}$.

\section{- Cementerios y servicios funerarios:}

Competencia municipal para determinar la ubicación de cementerios, para regular el uso de los mismos y para gestionar el servicio.

Asimismo, los ayuntamientos deben tener competencia para regular los servicios fúnebres y el traslado de cadáveres dentro del término municipal, así como para poder prestar servicios de este orden ${ }^{11}$.

\section{- Asistencia sanitaria:}

Competencia municipal para cooperar en la planificación y en la gestión de los centros públicos de asistencia sanitaria primaria existentes en su término municipal.

\footnotetext{
${ }^{10}$ La FEMP demanda también esta competencia. Para el Gobierno del Principado de Asturias, estas materias serían de concurrencia y necesaria colaboración entre la comunidad autónoma y los ayuntamientos.

${ }^{11}$ La FEMP se pronuncia también es este sentido.

El Gobierno del Principado de Asturias ha expuesto que esta materia ya viene siendo desarrollada por los ayuntamientos, y puede considerarse atribuible o delegable.
} 
Los ayuntamientos también han de tener capacidad para gestionar servicios sanitarios especializados o servicios hospitalarios, así como para participar en la planificación y en la dirección de la asistencia sanitaria pública que les afecte $^{12}$.

\section{- Servicios para la integración y la cohesión social:}

Se debe atribuir a los municipios competencias para regular y prestar los servicios sociales públicos de asistencia primaria, así como los especializados que se planteen en su ámbito territorial.

La competencia municipal en este ámbito debe incluir la capacidad de organizar y prestar servicios de atención a la dependencia, así como actividades y servicios para la protección o la reinserción de personas que lo requieran (mujeres maltratadas, menores, etc.).

De modo especial conviene reforzar las competencias municipales relacionadas con la inmigración, hasta asegurar que el ayuntamiento pueda desarrollar funciones efectivas de acogida y de integración social de los inmigrantes $^{13}$.

En general, las competencias municipales en materia de integración y cohesión social deben incluir la capacidad de regular y controlar el funcionamiento de los servicios privados existentes en el término municipal.

\section{- Deportes y ocio:}

Competencia de los municipios para ser titulares de, regular y, en su caso, gestionar los equipamientos deportivos y de ocio públicos existentes en su término.

\footnotetext{
${ }^{12}$ En ese sentido se encuentran también las propuestas de la FEMP. Para el Gobierno del Principado de Asturias, esta materia es irrenunciable para la Comunidad Autónoma aunque puedan ser delegables algunos aspectos en municipios de gran población (planificación y gestión de los centros públicos de atención primaria de su término municipal).

${ }^{13}$ La FEMP también ha aportado propuestas de mayores competencias en esta materia. También en este caso el Gobierno de Asturias considera que se trata de actuaciones que se están desarrollando de hecho por los ayuntamientos, por lo que procedería su atribución o delegación.
} 
Reconocimiento de la competencia municipal de sensibilización y de promoción o gestión de actividades, así como de cierta capacidad municipal para regular el funcionamiento y las actividades de las entidades sociales del deporte, todo ello con el fin de asegurar la máxima extensión de la práctica deportiva en la localidad ${ }^{14}$.

\section{- Cultura y patrimonio histórico-artístico:}

Competencia municipal para establecer, regular y gestionar los equipamientos culturales de carácter público de la localidad (bibliotecas, museos, archivo, teatro, centros polivalentes, etc.), así como para incidir en la localización y funcionamiento de los privados.

Los ayuntamientos también deben tener competencia para organizar, promover y regular todo tipo de actividades culturales que se celebren en la comunidad y para fomentar la creación y la producción artística.

Debe reconocerse asimismo la competencia municipal para crear, regular y proteger un posible catálogo local de bienes de valor o interés histórico ${ }^{15}$, artístico, arquitectónico, arqueológico, científico o similar, incluyendo la posibilidad de establecer limitaciones a los propietarios privados de los mismos, con el fin de garantizar su integridad y accesibilidad.

Competencia municipal también para participar en la catalogación de bienes del patrimonio cultural autonómico o estatal radicados en su término municipal y para participar en la regulación de su uso, acceso y protección.

\section{- Educación:}

Competencia municipal para localizar y promover los centros docentes públicos que requiera la comunidad, para cuidar de su mantenimiento y conservación y para regular su uso fuera del horario y del calendario escolar.

\footnotetext{
${ }^{14}$ La FEMP propone que se cambie la denominación por la de "Actividades físicas y deportivas", incluyendo una serie de demandas de mayores competencias municipales en la materia. El Gobierno asturiano considera también que es una materia atribuible o delegable a las entidades locales, porque ya la desarrollan de hecho.

${ }^{15}$ En esta línea está la propuesta aportada por la Federació de municipis de Catalunya. Salvo la protección del patrimonio histórico-artístico, que para el Gobierno asturiano debe entenderse concurrente, estas materias deben considerarse atribuibles o delegables, por ser ya ejercidas de hecho por los ayuntamientos.
} 
Competencia municipal para cooperar en la planificación y en la gestión de los centros públicos escolares existentes en su término municipal.

Los municipios también deben poder participar en el proceso de matriculación en los centros públicos y concertados radicados en su término municipal a fin de colaborar en una correcta distribución de los alumnos.

Capacidad de los ayuntamientos para organizar actividades extraescolares.

Capacidad de los ayuntamientos para participar en la programación de las actividades docentes, a fin de asegurar la conexión de la escuela con su entorno $^{16}$.

\section{- Ordenación y promoción de la actividad económica:}

Competencia municipal para regular el establecimiento, autorizar y promover todo tipo de actividades económicas en su término municipal, especialmente las de carácter comercial, artesanal y turístico, así como para procurar la mejora y la competitividad de sus estructuras productivas.

Competencia municipal para gestionar todo tipo de actividades productivas, en concurrencia con las empresas privadas, planificar estratégicamente el territorio, elaborar y aplicar políticas de dinamización socioeconómica, fomento del empleo y atención a los parados ${ }^{17}$.

\section{- Colaboración con la administración de justicia:}

Conviene reforzar las competencias municipales de colaboración con la administración de justicia, a fin de contribuir a hacerla más eficiente y próxima a los ciudadanos.

\footnotetext{
${ }^{16}$ Para el Gobierno del Principado de Asturias, se considera irrenunciable en tanto no esté definitivamente asentado el modelo educativo asturiano, aunque puedan ser delegables algunos aspectos que ya vienen siendo ejercidos por los municipios (mantenimiento y conservación, uso de instalaciones en horario extraescolar).

${ }^{17}$ La FEMP ha efectuado diversas propuestas en esta materia, como el establecimiento de Servicios Locales de Empleo. Para el Gobierno asturiano, se trata de una materia concurrente y de necesaria colaboración de la comunidad autónoma y los ayuntamientos.
} 
En este terreno podría analizarse la posibilidad de establecer mecanismos específicos de justicia de proximidad para resolver conflictos de vecindad y de justicia municipal $^{18}$.

\section{3.-Propuestas en materia de competencias}

De acuerdo con el análisis de situación expuesto en las páginas precedentes, la Comisión entiende que las propuestas con relación a las competencias locales deben concretarse en los siguientes extremos:

-En primer lugar, y desde una perspectiva material, la cuestión competencial debe girar alrededor de tres ejes:

a) una cláusula universal de atribución de competencias, en el sentido de afirmar que los municipios ostentarán competencias normativas y ejecutivas respecto de aquellos ámbitos materiales no reservados a otras instancias territoriales y que no estén expresamente prohibidos por la Ley.

b) un elenco de servicios locales mínimos, configurados como competencias en ámbitos materiales vinculados a la cláusula constitucional de Estado Social. Se plantea, pues, unificar los actuales artículos 26, relativo a los servicios mínimos de prestación obligatoria por los municipios, y 86.3, referente a la reserva a favor de los entes locales de actividades y servicios esenciales, fijando un listado material debidamente actualizado a la realidad actual, respecto de las que el municipio ejercerá las potestades normativas y ejecutivas correspondientes.

c) La enumeración de una serie de materias en las que se han de asegurar competencias a los municipios, asi como las correspondientes potestades, por existir un interés local, configurando un listado acorde con la realidad social y dotado de flexibilidad, en el sentido de que debe poder ser ampliado por la legislación sectorial.

- En segundo término, tal y como ya ha quedado apuntado, debe fijarse la atribución de las potestades que resulten procedentes en cada caso - normativas, ejecutivas y de gestión- respecto de los diferentes ámbitos materiales que correspondan a los municipios.

\footnotetext{
${ }^{18}$ El Gobierno asturiano considera que es una materia irrenunciable para la comunidad autónoma, máxime estando en la actualidad pendiente de transferencia por parte del Estado, aunque fuesen susceptibles de concurrencia o delegación los Juzgados de Paz.
} 
- En tercer lugar, deben fijarse expresamente con carácter normativo los principios básicos vinculados tanto al ejercicio como a la atribución de las competencias: autonomía, subsidiariedad, flexibilidad, proporcionalidad.

- En último extremo, se ha de proceder a la incorporación normativa del principio de suficiencia financiera vinculado a las competencias. Para ello resulta esencial que cualquier previsión de atribución competencias vaya acompañado de la correlativa previsión de financiación. Y ello, porque a efectos de mantener un equilibrio entre las competencias y los medios necesarios para su ejercicio, a cada nueva transferencia de competencia debe corresponder su modo de financiación en forma de nuevo recurso fiscal, fuente procedente de transferencia, de atribución de personal o de cesión de estructuras materiales, pudiendo concurrir todos al tiempo, varios o uno sólo.

\section{LAS ESTRUCTURAS TERRITORIALES DE GOBIERNO LOCAL}

\section{Diagnóstico}

\subsection{El Sistema Español}

España tiene una estructura municipal formada por más de 8.100 municipios de muy diferentes características y población, y con una distribución territorial poco homogénea. En líneas generales no se ha producido, contemporáneamente, una reforma importante del mapa municipal al estilo de las realizadas, hace varias décadas, en otros países europeos. Por ello, con ese elevado número de municipios, de los cuales cerca del $90 \%$ no superan los 5.000 habitantes, se hace imprescindible reconocer la imposibilidad de abordar la delimitación competencial de las entidades locales sin considerar la necesidad de proponer soluciones adecuadas a esa fragmentación y sus consecuencias.

En el análisis del sistema local español no se puede obviar, pues, que a pesar de las notorias dificultades que muchos municipios muestran para la prestación de los servicios mínimos, no es realista plantear la reducción del mapa municipal en aras de alcanzar dimensiones idealmente más eficaces, pues no ha habido en España verdaderos intentos de "racionalización" y "simplificación" del mapa municipal en el pasado reciente ni se vislumbran tampoco en el futuro inmediato.

En tanto que el municipio es el primer nivel de representación democrática en el territorio y teniendo en cuenta que España es un país extenso y relativamente poco poblado, debemos considerar positiva la existencia de ayun- 
tamientos y de otras entidades locales, incluso en comunidades muy reducidas. Es decir, tampoco debemos perder de vista los aspectos ventajosos de la existencia de un elevado número de municipios; esa circunstancia aporta valores positivos de diversa naturaleza, y que van desde la existencia de más instituciones con representación democrática hasta la preservación del medio ambiente o del acervo histórico o cultural en el medio rural.

La LRBRL confió de una parte en la capacidad asociativa de los municipios y de otra en la atribución de un papel centrado en las funciones de cooperación económica, jurídica y técnica de las provincias como entidades locales de segundo nivel, como instrumentos para alcanzar las economías de escala necesarias para garantiza la prestación de los servicios municipales básicos.

REGISTRO DE ENTIDADES LOCALES: ENTIDADES INSCRITAS A 1-1-2005

\begin{tabular}{|l|c|c|c|c|c|c|c|c|c|}
\hline & MUNI & PRO V & ISLA & EATIM & MANC & COM & ARE A & OTRA & TOTAL \\
\hline Andalucía & 770 & 8 & & 44 & 86 & & & & 908 \\
\hline Aragón & 730 & 3 & & 43 & 71 & 32 & & & 879 \\
\hline Asturias, Principado de & 78 & 1 & & 38 & 18 & & & 1 & 136 \\
\hline Balears, Illes & 67 & 1 & 3 & 1 & 7 & & & & 79 \\
\hline Canarias & 87 & 2 & 7 & & 17 & & & & 113 \\
\hline Cantabria & 102 & 1 & & 523 & 18 & & & & 644 \\
\hline Castilla y León & 2.248 & 9 & & 2.224 & 235 & 1 & & 2 & 4.719 \\
\hline Castilla-La Mancha & 919 & 5 & & 38 & 126 & & & & 1.088 \\
\hline Cataluña & 946 & 4 & & 56 & 67 & 41 & 2 & & 1.116 \\
\hline Comunidad Valenciana & 542 & 3 & & 7 & 56 & & 2 & & 610 \\
\hline Extremadura & 383 & 2 & & 24 & 77 & & & & 486 \\
\hline Galicia & 315 & 4 & & 9 & 38 & & & & 366 \\
\hline Madrid, Comunidad de & 179 & 1 & & 2 & 44 & & & & 226 \\
\hline Murcia, Región de & 45 & 1 & & & 8 & & & & 54 \\
\hline Navarra, Comunidad Foral de & 272 & 1 & & 356 & 55 & & & 2 & 686 \\
\hline Ciudades de Ceuta y Melilla & 2 & & & & & & & & 2 \\
\hline Rioja, La & 174 & 1 & & 4 & 17 & & & & 196 \\
\hline País Vasco & 251 & 3 & & 339 & 35 & 7 & & & 635 \\
\hline TOTAL & 8.110 & 50 & 10 & 3.708 & 975 & 81 & 4 & 5 & 12943 \\
\hline
\end{tabular}


Ya se ha puesto de manifiesto el importante papel de los gobiernos locales en la consolidación del estado social y, por tanto, en la mejora de la cohesión social, siendo piezas clave en un desarrollo policéntrico y equilibrado del territorio, una referencia para el ciudadano que necesita encontrar en lo próximo referencias frente a los procesos globalizadores, etc.; ámbitos todos ellos en los que el gobierno local como gobierno de los intereses de la comunidad y lo próximo juega un papel esencial.

Partimos, pues, de una realidad que nos impone el mantenimiento del mapa municipal, sobre el cual el Estado no puede actuar de forma directa. Ahora bien, los principios que han de inspirar la reforma local, autonomía, subsidiariedad, y la garantía de la prestación de servicios locales de calidad, no se pueden llevar a la práctica si no se articula un sistema local que los haga homogéneos en el territorio. Este sistema ha de propiciar el cumplimiento de la misión local manteniendo sus objetivos de la defensa y la gestión de los intereses locales en la esfera del gobierno local.

El objetivo de los gobiernos locales que es la ordenación de su territorio y la prestación de servicios de calidad, así como la participación en todos los asuntos que preocupen a su comunidad, no podrá ser alcanzado por la mayoría de ellos sin el concurso de entes intermedios locales de carácter necesario (las diputaciones e instituciones similares, etc.) y de otras entidades locales que en función de los intereses y características de los diferentes territorios puedan crear las CCAA, (comarcas, áreas metropolitanas, etc.), así como de aquellas entidades intermunicipales de carácter voluntario (mancomunidades) que ya tienen tradición en nuestro sistema local.

$\mathrm{Al}$ conjunto de gobiernos locales hemos convenido en denominarlo el "sistema local". Se trata de contemplar la promoción de los poderes locales potenciando un conjunto de entes que, cooperando de una manera concertada, sean capaces de dar respuesta a las demandas de los municipios.

En este sistema reticular, el municipio es el nodo principal que en su relación con los otros municipios y las otras entidades locales va a encontrar el espacio adecuado para desarrollar sus políticas. Es en este entorno reticular, en la búsqueda de economías de escala y sinergias que ayudan a alcanzar objetivos en aquellas políticas que desbordan las posibilidades municipales, donde adquieren relevancia las entidades intermedias locales y en la que los otros entes locales no tienen sentido sin los nodos municipales. Esta perspectiva de la red nos obliga a referirnos a un espacio intermunicipal existente pero necesitado de nuevas definiciones y que supone el soporte a la existencia de lo 
que de ahora en adelante denominaremos "entidades intermunicipales". Esta denominación explica mejor el tipo de relación que se debiera establecer entre las diferentes integrantes del sistema.

\subsection{La Intermunicipalidad en España}

Como hemos dicho, en un sistema local como el nuestro se hace esencial la actuación de entes intermedios para numerosos gobiernos locales.

La Constitución de 1978 estableció la necesariedad de la provincia en las comunidades autónomas pluriprovinciales, y de las islas en los archipiélagos, reconociendo autonomía a ambas. Y las comunidades autónomas, en uso de sus competencias sobre ordenación territorial y régimen local han creado nuevos entes intermunicipales (áreas metropolitanas y comarcas). A las anteriores se suman otras entidades intermunicipales que tienen carácter voluntario: las mancomunidades. Como ha destacado el informe de los expertos del Consejo de Europa sobre el borrador del Libro Blanco, hay que distinguir agrupaciones y asociaciones de municipios.

Las mancomunidades responden a la necesidad de aunar esfuerzos entre municipios para prestar servicios. Y su desarrollo está condicionado por la voluntad de los propios municipios de asociarse para mejorar la calidad de los servicios locales. Esa voluntad responde habitualmente a necesidades de economías de escala en la gestión de los servicios públicos, por lo que no puede sorprender la proliferación de esta institución. De hecho, aunque la presencia de mancomunidades no es uniforme en todas las comunidades autónomas, en la actualidad aproximadamente un $70 \%$ de los municipios españoles están integrados en alguna mancomunidad.

La figura del área metropolitana ha sido poco desarrollada en España, y responde a la necesidad de gestionar los complejos servicios de las aglomeraciones urbanas y mejorar la competitividad de sus ciudades, necesidad cada vez más patente en una sociedad crecientemente urbanizada y donde normalmente las grandes aglomeraciones urbanas desbordan los límites administrativos de la ciudad central, haciendo necesaria la planificación y gestión conjunta o coordinada de los servicios más importantes a escala metropolitana. No puede sorprender que el debate metropolitano constituya en la actualidad uno de los grandes ejes de las políticas locales en todos los países desarrollados; aquí nos encontramos ante un fenómeno de enorme complejidad, que afecta a las zonas más dinámicas de los distintos países, y que por ello requiere una atención prioritaria por parte de los poderes públicos. 


\section{La Provincia}

\subsection{Situación Actual}

La provincia como entidad local queda definida claramente en el título III de la LRBRL. En pocos artículos se realiza un diseño escueto pero bien perfilado de esta entidad que debe formar parte de la misma comunidad política local que los municipios. La previsión constitucional de la provincia garantiza la existencia de un ente intermedio en todas aquellas comunidades autónomas pluriprovinciales. Las funciones que entendemos que debe cumplir son las de conseguir unos territorios equilibrados desde el punto de vista de los servicios públicos, del desarrollo económico, y del bienestar de todos los ciudadanos independientemente del lugar donde habiten. La Constitución garantiza la función de cooperación que debe desarrollar la agrupación de municipios, más que su forma concreta de gobierno, pues expresa que el órgano de gobierno y administración de la provincia será la diputación u otras corporaciones de carácter representativo; es decir, entendemos que prevalece su condición de agrupación municipal para cooperar y garantizar la autonomía municipal sobre el órgano de gobierno. Lo importante no es el nombre, es la función.

La obligatoriedad de su existencia, derivada de la Constitución, motiva que hagamos una especial reflexión sobre el papel de las Diputaciones, y formulemos propuestas para conseguir su correcto acomodo en el estado autonómico y el mayor desarrollo posible de sus funciones de apoyo a los municipios.

Con carácter preliminar, consideramos interesante examinar algunos modelos europeos de entidades similares a la provincia española. Los procesos de reestructuración de sus niveles territoriales de gobierno, realizados, o en marcha, por la mayoría de los países europeos, nos muestra como adquiere relevancia un segundo nivel en los principales países de la Unión Europea: las Provincias italianas, los Départaments franceses, los Kreise alemanes, las Provinces belgas, los County Councils británicos e irlandeses, los de Suecia y Dinamarca, las provincias holandesas y finlandesas y los Nomi griegos.

Del análisis comparado se pueden extraer al menos cuatro elementos comunes:

a) La mayoría de los países tienen administraciones de segundo nivel, sobre todo con una función de coordinación y gestión de servicios y políticas supramunicipales. 
b) Las administraciones locales de segundo orden están en reconsideración en bastantes Estados, aunque con intensidades diferentes. Los principales factores que justifican las reformas son: la introducción de niveles regionales de gobierno, que en algunos países son una respuesta a las dinámicas de ingreso a la UE; la voluntad de fortalecer los municipios; y por las dinámicas descentralizadoras de cada país.

c) Una tendencia general a establecer relaciones interadministravas más complejas tanto en su dimensión vertical (de relación con los niveles superiores de gobierno y con los municipios), como en la horizontal (con otros entes de cooperación municipal o con áreas metropolitanas).

d) Con relación al sistema de elección de los órganos de gobiernos de estas administraciones locales de segundo grado la característica más significativa es la presencia dominante de los sistemas de elección directa. Así se produce para el "consejo general" en Francia, el "consejo del condado" en Alemania, el "consejo provincial" en Bélgica, el "consejo del condado" en el Reino Unido y en Irlanda, el "parlamento provincial" de los Países Bajos, y el "consejo de prefectura" en Grecia. Una primera observación parece poner de manifiesto la existencia de una correlación, en los sistemas comparados analizados, entre la presencia de sistemas de elección directa y la asignación precisa de competencias sobre materias específicas.

Ahora bien, conviene reflexionar sobre las razones de diferente índole que no han permitido a esta entidad una consolidación definitiva en nuestro panorama institucional, ni el despliegue de todas las potencialidades que el legislador había previsto para las diputaciones. Se trata de analizar aquellas cuestiones que han actuado como barreras o limitaciones de manera que en el futuro proceso de reforma puedan reorientarse algunos aspectos.

En primer lugar detectamos la poca homogeneidad de las características de los gobiernos provinciales, agravada por la inexistencia de estas entidades locales en las comunidades autónomas uniprovinciales. Esto ha hecho más difícil la generalización de un modelo de referencia de administración intermedia. Además, la existencia de regímenes especiales, interesante en cuanto diversifican el diseño general, no han actuado en beneficio de su desarrollo. En las comunidades autónomas uniprovinciales, la organización y funciones de la diputación fueron asumidas, por razones de racionalización administrativa e institucional, por las comunidades autónomas, mientras que en Baleares lo han sido por las Islas. En el caso de Canarias, la entidad intermedia realmente significativa es la Isla, pues la provincia como entidad local sólo se mantie- 
ne mediante instituciones con escasas funciones reales (las mancomunidades interinsulares de cabildos), gozando además de muchas más competencias que la provincia de régimen común. En el País Vasco, la importancia de los denominados "territorios históricos" (de hecho las provincias como entidad local en dicha comunidad autónoma) es muy superior debido al peculiar reparto de competencias entre las instituciones comunes y dichos territorios.

Dada la previsión constitucional de la provincia, lo razonable es, pues, buscar el correcto encaje de la provincia en el Estado autonómico; teniendo en cuenta también, como hemos apuntado, que la provincia no es la única forma de intermunicipalidad posible en nuestro ordenamiento y que las comunidades autónomas deben tener la opción de configurar la red intermunicipal que mejor se adapte a sus características propias.

Es natural que la coexistencia de comunidades autónomas y provincias que ha querido la Constitución exija un encaje, y es también comprensible que durante un período se hayan producido tensiones en algunas comunidades autónomas. En efecto, posiblemente no se ha producido ese correcto encaje de las diputaciones dentro de las Comunidades Autónomas tras el nacimiento de éstas. Y ambas han sido las responsables de tal situación. Por un lado, las comunidades autónomas nacieron con una importante aspiración competencial y de presencia en su territorio, encontrando en las diputaciones provinciales una competidora, y una institución propicia para ser desplazada. Por su parte, las diputaciones provinciales posiblemente no centraron su actividad en el apoyo a los municipios y continuaron durante mucho tiempo desarrollando actividades en competencia con las comunidades autónomas y ejerciendo así un papel que no les corresponde.

Se han señalado diversos factores por los que las diputaciones no han desplegado con plenitud el papel institucional diseñado por el legislador:

a) en primer lugar, la existencia de iniciativas legislativas autonómicas que han articulado la transferencia de competencias y recursos económicos de las diputaciones a las comunidades autónomas. Sobre estas iniciativas cabe señalar que paradójicamente no han estado dirigidas, en general, a reubicar aquellos servicios que prestaban las diputaciones antes de la LRBRL y que con la reforma institucional se han situado en la esfera de competencias de las comunidades autónomas. Han tenido por objeto invadir las competencias en cooperación local y efectuando una laminación (leyes sectoriales que transfieren competencias al ámbito autonómico) y un control de los recursos económicos de las diputaciones. 
b) en segundo lugar, la interpretación extensiva de la técnica de la coordinación competencial de las comunidades autónomas respecto a las competencias provinciales.

c) y finalmente, las comunidades autónomas no hay hecho uso de los instrumentos estatutarios de delegación de competencias autonómicas en las diputaciones. Sobre este aspecto hay que señalar que a pesar de que la posibilidad está recogida explícitamente en varios Estatutos (Andalucía, Valencia, Aragón, Castilla-La Mancha, Extremadura y Castilla y León), pocas han sido las iniciativas y de carácter muy limitado e inexistentes las experiencias de utilización de las diputaciones como administración indirecta que en algún momento se había planteado como paradigma de racionalidad (informe de la Comisión de expertos sobre autonomías, de 1981).

A las razones señaladas cabe añadir que la estructura de ingresos de las diputaciones de régimen común ha estado muy condicionada por la preeminencia del capítulo relativo a las transferencias corrientes (el 73,5\% de los ingresos ordinarios en el ejercicio 2002) que se sustenta casi en exclusividad (mas del 90\%) de las transferencias provenientes del Estado. La estrecha vinculación de los ingresos de las diputaciones de régimen común a la PIE, de forma significativamente mas acusada que en el caso de las finanzas de los ayuntamientos, explica el menor crecimiento de sus ingresos corrientes. En el periodo 1986-2003 los ingresos corrientes (capítulos 1 a 5) de las diputaciones crecieron en términos nominales el $151 \%$, mientras que los municipios crecieron en $288 \%$. Dicha evolución ha generado un retroceso real en el nivel de ingresos de las diputaciones con relación a la riqueza nacional (PIB), que evoluciona negativamente en dicho periodo del $0,74 \%$ al $0,48 \%$ del PIB. Por su parte, los municipios han mantenido prácticamente inalterado el peso relativo de sus ingresos corrientes sobre el PIB, pues ha evolucionado del 2,88\% al $2,89 \%$.

A este aspecto se suma la cuestión de los llamados "servicios impropios", que son aquellos que estando actualmente en la esfera competencial autonómica continúan siendo prestados por las diputaciones hipotecando una parte de los presupuestos provinciales que no pueden ser destinados a las tareas que el legislador ha previsto para las diputaciones, esencialmente la cooperación local.

Cuadro: Evolución de los ingresos corrientes de los municipios y de las diputaciones de régimen común (Presupuestos iniciales) 


\begin{tabular}{|c|c|c|c|c|c|c|}
\hline \multicolumn{3}{|c|}{ Municipios } & \multicolumn{6}{c|}{ Diputaciones de Régimen Común } \\
\hline Años & $\begin{array}{c}\text { Capítulos } \\
1-5\end{array}$ & $\begin{array}{c}\text { índex } \\
\text { millones } \\
\text { de }\end{array}$ & $\begin{array}{c}\% \\
\text { sobre }\end{array}$ & $\begin{array}{l}\text { Capítulos 1-5 } \\
\text { millones de }\end{array}$ & $\begin{array}{c}\text { Index } \\
1986=100\end{array}$ & $\begin{array}{c}\text { \% sobre } \\
\text { el PIB }\end{array}$ \\
& & & & & \\
1986 & $5.558,51$ & 100,00 & 2,86 & $1.428,49$ & 100,00 & 0,74 \\
1987 & $6.293,43$ & 113,22 & 2,90 & $1.499,28$ & 104,96 & 0,69 \\
1988 & $7.257,61$ & 130,57 & 3,01 & $1.582,19$ & 110,76 & 0,66 \\
1989 & $8.667,44$ & 155,93 & 3,20 & $1.736,36$ & 121,55 & 0,64 \\
1990 & $9.962,62$ & 179,23 & 3,31 & $1.857,67$ & 130,04 & 0,62 \\
1991 & $11.374,16$ & 204,63 & 3,45 & $1.897,13$ & 132,81 & 0,57 \\
1992 & $12.978,48$ & 233,49 & 3,65 & $2.128,42$ & 149,00 & 0,60 \\
1993 & $14.047,83$ & 252,73 & 3,83 & $2.255,95$ & 157,93 & 0,62 \\
1994 & $14.651,05$ & 263,58 & 3,76 & $2.315,52$ & 162,10 & 0,59 \\
1995 & $15.254,57$ & 274,44 & 3,48 & $2.449,90$ & 171,50 & 0,56 \\
1996 & $16.396,66$ & 294,98 & 3,53 & $2.607,47$ & 182,53 & 0,56 \\
1997 & $17.503,11$ & 314,89 & 3,54 & $2.720,19$ & 190,42 & 0,55 \\
1998 & $18.680,26$ & 336,07 & 3,54 & $2.854,94$ & 199,86 & 0,54 \\
1999 & $20.159,45$ & 362,68 & 3,57 & $2.969,15$ & 207,85 & 0,53 \\
2000 & $22.048,54$ & 396,66 & 3,61 & $3.100,70$ & 217,06 & 0,51 \\
2001 & $23.159,10$ & 416,64 & 3,55 & $3.245,98$ & 227,23 & 0,50 \\
2002 & $24.995,14$ & 449,67 & 3,59 & $3.412,97$ & 238,92 & 0,49 \\
2003 & $21.489,45$ & 386,60 & 2,89 & $3.594,34$ & 251,62 & 0,48 \\
\hline
\end{tabular}

En conclusión, en este contexto institucional y político, las diputaciones de régimen común no han podido desarrollar al máximo las misiones que el legislador definió en la LRBRL. Es verdad que algunas diputaciones, durante estos últimos veinte años, han puesto en marcha procesos de mejora y reorientación institucional con diferentes resultados, en ocasiones muy interesantes. Pero, en líneas generales, estos procesos han estado limitados por las razones expuestas anteriormente.

Debemos tener en cuenta también que durante este período las diputaciones han consolidado un importante instrumento para la cooperación local: el Plan Provincial de Obras y Servicios. Configurado como el cauce ordinario de cooperación local del Estado, las diputaciones provinciales son las encargadas de desarrollarlo, además de financiarlo parcialmente. Este instrumento está totalmente asentado y es valorado positivamente de forma mayoritaria. Es- 
te plan, de carácter anual, ha contribuido de forma fundamental a la dotación de infraestructuras básicas en los municipios españoles, y es importante también que destaquemos el componente de solidaridad interterritorial que conlleva y el fuerte engarce que ha propiciado entre las diputaciones y los municipios.

Seguramente el Plan Provincial ha cumplido satisfactoriamente sus objetivos durante varias décadas y sea precisa su revisión o actualización, pero la Comisión quiere destacar su valor como una base metodológica de procesos de concertación entre municipios y provincias, ayuntamientos y diputaciones, que muestra como es posible definir políticas a partir de herramientas comunes de análisis de las necesidades del territorio y la determinación consensuada de objetivos. Como detallaremos a continuación, la concertación que se ha venido practicando habitualmente en el marco del Plan Provincial es un mecanismo que debería extenderse a todas las posibilidades de cooperación que la diputación esté en condiciones de poner al servicio de los municipios.

\subsection{El Nuevo papel de la Provincia como Entidad Local}

Como hemos dicho, la garantía de que cualquier habitante, independientemente del lugar donde viva, tendrá acceso a servicios de calidad, hacen necesarios a los entes intermedios. Además, los entes intermedios deben ayudar a que los municipios puedan ejercer sus competencias y a que los gobiernos locales puedan desarrollar sus políticas, supliendo la falta de capacidad de gran número de ellos.

La Comisión considera que es precisa una reorientación de las diputaciones provinciales para que ejerzan de auténticos espacios intermedios obligatorios de cooperación dentro del sistema local. Con ese propósito, las diputaciones han de ser eficaces instrumentos al servicio de los municipios para aquellas actuaciones para las que éstos no tengan capacidad suficiente o en aquellos otros casos en que quieran mejorar la calidad de los servicios que están prestando. En los casos en que los municipios consideren que es la mejor opción, las diputaciones deberían ser también (y en algún caso así ocurre en la actualidad) los instrumentos de gestión común de servicios locales. Es decir, la diputación debe ser una institución de cooperación con los municipios muy especializada, y debe orientar toda su actividad a hacer efectivas las demandas municipales.

\section{A) La cooperación local como función esencial de las diputaciones}

La función central de las diputaciones debe ser, por lo tanto, la cooperación local, entendida en su sentido más amplio porque los municipios tienen 
necesidades de cooperación muy diversas. La ley debería asegurar a la diputación la competencia para la cooperación local, porque esta es la principal razón de ser de la misma, y porque en esa tarea está especializada mejor que ninguna otra institución pública. Para que se produzca una correcta ubicación de la provincia en el estado autonómico, y dejen de existir interferencias, solapamientos, o duplicidades entre distintas administraciones, el marco jurídico debe asignar a las diputaciones una competencia funcional en cooperación local y concretar los ámbitos o materias preferentes de dicha cooperación. Esta asignación debe ser lo suficientemente amplia para garantizar que ningún servicio local es absorbido automáticamente por la comunidad autónoma sin poder ser prestado por la diputación, porque en ese caso, el nivel local de gobierno se vería perjudicado.

La propuesta del borrador de este Libro Blanco de que la diputación tenga este marcado carácter instrumental o funcional para los municipios ha sido criticada alegando que se diseña una provincia desprovista de competencias, o con competencias endebles y subordinada a los municipios ${ }^{1}$. En realidad, el propósito de la Comisión no es ese, sino el de encajar correctamente a las diputaciones y propiciar que todo su potencial esté dedicado favorecer la autonomía municipal; la Comisión no propone unas diputaciones subordinadas a los municipios, sino al servicio de éstos, porque entiende que esa es esencialmente la razón de ser de su garantía constitucional. Este papel de la provincia ha sido bien valorado en el informe de expertos del Consejo de Europa sobre el borrador de Libro Blanco; para ellos, aunque no comparten la necesidad de la elección indirecta de los diputados (la Comisión considera que la elección directa se corresponde mejor con competencias materiales cuyo ejercicio es valorado por los ciudadanos, y las competencias funcionales sobre las materiales de los ayuntamientos se corresponden mejor con una elección indirecta), la solución del Libro Blanco es coherente con el objetivo estratégico de reforzar los municipios a través de las provincias. Aprueban también la propuesta de reforzar la función de la provincia en el ejercicio a título subsidiario de las competencias municipales y sugieren incidir más en la distinción entre las agrupaciones de municipios y las asociaciones municipales que deriva de la propia Constitución.

Entendemos que las posibilidades de la cooperación local son muy amplias, y sin ánimo exhaustivo, pues como dijimos, las demandas de los muni-

\footnotetext{
${ }^{1}$ En ese sentido se manifiestan las aportaciones de la Junta de Castilla y León y de la Diputación de Ourense
} 
cipios evolucionan, podemos sugerir una serie de aspectos en los que las diputaciones deberían emplear su esfuerzo.

- Creación y mantenimiento de redes de servicios municipales.

- Formación de los electos y empleados municipales.

- Asesoramiento jurídico, económico, técnico, administrativo y de gestión.

- Suministro de bienes en especie.

- Ejecución de obras o prestación de servicios por la propia diputación.

- Tramitación de expedientes administrativos por delegación de los ayuntamientos.

- Desempeño de funciones técnicas por la propia diputación.

- Asistencia administrativa en el ejercicio de las funciones reservadas a los funcionarios con habilitación de carácter nacional.

- Asistencia a la creación y al funcionamiento de mancomunidades, consorcios u otras formas asociativas legalmente previstas.

Se trata, sin duda, de profundizar en la cooperación y, en otros casos, de ampliar los terrenos en los que las diputaciones ya trabajan, y con notable éxito en algunas ocasiones. Las diputaciones actualmente desarrollan importantes tareas que son instrumentales para los municipios, pero cuya importancia no es menor. Podemos referirnos a la asistencia en materia de padrón municipal, catastro, cartografía, o a las importantes tareas de la recaudación de los tributos municipales, o de gestión de los residuos sólidos urbanos. En otros casos, sencillamente basta con que los servicios técnicos de las diputaciones (habitualmente de gran especialización) pongan su potencial a disposición de los ayuntamientos. Los ejemplos pueden ser múltiples, y sólo por exponer alguno, las diputaciones deberían prestar apoyo en la elaboración de las relaciones de puestos de trabajo, selección de personal, elaboración de inventarios de bienes, catálogos de bienes histórico-artísticos, pliegos de cláusulas técnicas y administrativas, formación de mesas de contratación (en este último ámbito, el de la contratación administrativa, las posibilidades de cooperación de las diputaciones provinciales son muy amplias e incluso algunas han sido propues- 
tas en el Informe de la Comisión de expertos para el estudio y diagnóstico de la situación de la contratación pública, del Ministerio de Hacienda, año 2004).

En el fondo de casi todas las posibilidades de cooperación subyace la puesta a disposición de los municipios del trabajo del personal de las diputaciones. Ciertamente, es este un aspecto que rara vez se tiene en cuenta, porque no es cuantificado económicamente al ser aportado por la administración provincial. No obstante, debemos hacer mucho hincapié en la importancia de este factor, que sin duda alguna es el capital más importante que poseen las diputaciones y que es la clave en su configuración como gobierno local que ha de suplir las deficiencias de los municipios de escasa capacidad para desarrollar las competencias que les corresponden. Los recursos humanos con los que cuentan las diputaciones provinciales son el núcleo en torno al cual debe girar la actividad de las mismas; y ello, porque acumulan la mayor experiencia y conocimiento del ámbito municipal de que dispone el conjunto de las administraciones públicas españolas. Como decimos, es este un factor no siempre suficientemente valorado, pero que es de capital importancia: por un lado, porque la realidad municipal española demuestra que la gran mayoría de los municipios (precisamente aquellos de escasa capacidad, en los que debe aplicarse a fondo la diputación) no sólo no cuentan, sino que entendemos que nunca contarán con los profesionales técnicos necesarios para una serie de tareas (decimos que nunca contarán no sólo por la carencia de recursos económicos, sino porque probablemente no sería eficiente que aspirasen a emplear sus recursos en ello: para eso deben estar las diputaciones, que ya cuentan con una plantilla muy diversificada de profesionales).

\section{B) Otras competencias}

La Comisión considera que el legislador básico debe configurar un mínimo común para los gobiernos locales, y que con relación a la provincia, el mínimo común consiste en garantizar un gobierno local intermedio en las comunidades autónomas pluriprovinciales, con la finalidad de cooperar con los municipios para que estos puedan desarrollar sus competencias y políticas, así como para procurar la solidaridad, eficiencia y economías de escala dentro de la provincia.

No obstante, la diversidad de los distintos territorios, así como las competencias autonómicas en materia de régimen local y ordenación del territorio no pueden ser ignoradas. El diseño común de las diputaciones por parte del legislador básico ha de permitir que aquellas comunidades autónomas que lo deseen atribuyan mayores competencias a los entes provinciales, pues nada 
obsta a que así sea; pero debe también garantizar un mínimo competencial que no vacíe de contenido la garantía de la autonomía provincial establecida por la Constitución, y concebida a favor de los municipios.

Respecto a la posibilidad de que las diputaciones sean gestoras de competencias de carácter territorial, el nuevo marco jurídico podría concretar aquellos campos en los que mediante la transferencia, la delegación, o el ejercicio de competencias locales de carácter supramunicipal, las diputaciones podrían actuar. Esta situación ya se da, por ejemplo, en los Consells Insulars, y podría generalizarse a las diputaciones de régimen común, en función de la voluntad de la comunidad autónoma (por ser la titular de la mayoría de las competencias). Efectivamente, la prestación de servicios públicos de carácter intermunicipal y en su caso intercomarcal, la cooperación en el fomento del desarrollo económico y social y en la planificación en el territorio provincial o el fomento de los intereses peculiares de la provincia, son cometidos que tiene la provincia de difícil concreción si no es en la gestión de determinados servicios de proximidad (carreteras locales, espacios no urbanizables de interés natural, mejora forestal, gestión medioambiental, residuos, transporte y movilidad intermunicipal, turismo rural, etc.).

La Comisión considera que el objetivo que debe cumplir el legislador básico estatal es asegurar un correcto encaje de la provincia en el estado autonómico (aunque la responsabilidad de ese correcto encaje no es sólo estatal, también lo es autonómica, dada la garantía constitucional de la provincia), permitiendo que la diputación desarrolle un papel esencial a favor de los municipios, sin merma de las competencias autonómicas. Por ello, la Comisión entiende que las alegaciones en el sentido de que el borrador de Libro Blanco potencia a las diputaciones como contraposición a las comunidades autónomas $^{2}$ no son acertadas, pues el propósito es el de hacer viables las funciones de dos niveles de gobierno, el autonómico y el provincial, garantizados constitucionalmente, y además permitir que cada comunidad autónoma opte por dotar de mayor o menor número de competencias a sus diputaciones provinciales.

C) La relación de las diputaciones con los ayuntamientos. El trabajo en red y la concertación

Las diputaciones han de trabajar conjuntamente con los municipios, asumiendo que su posición no es de superioridad jerárquica frente a aquellos, si-

\footnotetext{
${ }^{2}$ Esa es la posición de los gobiernos autonómicos de Aragón y Cataluña.
} 
no que tanto municipios como provincias integran una misma comunidad política local. La mejor forma de hacerlo es el trabajo en red. Las diputaciones del futuro tienen en el trabajo en red su metodología principal; trabajar en red significa hacerlo conjuntamente para conseguir unos objetivos comunes, sumando esfuerzos y recursos, optimizando rendimientos. Uno de los objetivos de las diputaciones en su misión de cooperación es la constitución de redes intermunicipales de gestión y prestación de servicios locales. En estas redes los municipios han de desempeñar también un papel mucho más activo, ya que la relación que se tiene que establecer entre los diferentes actores de la red es multidireccional. Los municipios se convierten en un agente más de la prestación de servicios que entre otras tareas, aporta la recogida de información necesaria para el perfeccionamiento de la red.

Las características del trabajo en red son: concertación, como base para la configuración de las redes entre los ayuntamientos y la diputación; intercambio de experiencias y conocimientos que ayudan al establecimiento de vínculos entre los miembros; optimización de recursos humanos, técnicos y materiales al aplicar economías de escala; capacidad de respuesta más rápida dada la implicación de los ayuntamientos en la red; flexibilidad, pues cada red puede tener objetivos diferentes y miembros diferentes.

En consecuencia con la función de cooperación a las necesidades municipales, la diputación debe estar atenta a las demandas de los ayuntamientos, para que sean estos quienes determinen en qué ámbito concreto necesitan la ayuda de la diputación.

Ya hemos puesto de manifiesto la necesidad de reducir el gran espacio que ocupan las subvenciones, porque son condicionadas en su aplicación, discontinuas en el tiempo, y graciables en su concesión. La subvención no es una auténtica financiación, pues no se compadece bien con una autonomía local bien entendida. Por ello, las diputaciones deben abandonar este tipo de actividad. La misión de la diputación no es la de financiar a los municipios, pues según la Constitución, esta financiación consiste en tributos propios y participación en los estatales y autonómicos. Por eso, las aportaciones económicas de las diputaciones hacia los municipios deberían ir siempre ligadas a otros tipos de cooperación: técnica, económica, jurídica, etc. Como hemos expresado anteriormente, la solvencia técnica es el mejor aporte de las diputaciones a los municipios, pues la aislada transferencia económica no aporta nada la intervención de la administración provincial.

Para posibilitar que los municipios expresen sus demandas de cooperación, el mejor método puede ser el de la concertación. Las diputaciones de- 
ben concertar individualmente con los municipios el contenido de la cooperación; mediante la concertación, la diputación no impone a los municipios una línea de cooperación al modo en que lo hacen las subvenciones, y son los ayuntamientos quienes determinan qué cooperación quieren de la diputación, pudiendo así desarrollar las políticas propias para las que fueron elegidos democráticamente por los ciudadanos. La concertación incentiva el establecimiento de prioridades políticas por parte de los ayuntamientos, estimulando así el buen gobierno.

Las diputaciones pueden ser instituciones idóneas para la concertación de la cooperación, pues en gran medida, el Plan Provincial de obras y servicios consiste en un proceso de concertación en el que los municipios determinan qué obras o servicios van a ser ejecutados por el plan durante el año. Sin perjuicio de que el Plan Provincial de obras y servicios pudiera ser objeto de alguna actualización, la figura ha demostrado ser de gran eficacia, y además de contribuir notablemente a la dotación de infraestructuras básicas en los municipios españoles, queremos destacar ahora la metodología para su elaboración. Lo que proponemos es que las Diputaciones extiendan el método del Plan Provincial a todas las líneas en que es posible la cooperación con los municipios. De este modo, la diputación pondría a disposición de los municipios un catálogo de los posibles ámbitos en los que tiene capacidad para cooperar, y los municipios formulan sus prioridades de antemano con relación a las actuaciones que desean de la administración provincial.

El método de la concertación debe estar también acompañado de medidas que aseguren la transparencia. Así, tanto las prioridades expresadas por los municipios como las actuaciones que va desarrollando la diputación en cada municipio deben ser públicas. Así se consigue facilitar un seguimiento de la acción de la diputación en todo el territorio, facilitando su visualización institucional. Por otro lado, las actuaciones de la diputación deben cuantificarse económicamente, con el único fin de poner en valor la actividad desarrollada (cuestión que, como dijimos, no siempre es tenida en cuenta cuando se trata de la asistencia de profesionales de la diputación).

\section{PROPUESTAS}

Primera.- Es preciso compatibilizar las distintas fórmulas de intermunicipalidad admisibles en nuestro ordenamiento (es decir, deben evitarse solapamientos entre la fórmulas previstas como necesarias por la Constitución, las que puedan crear las comunidades autónomas, y las que surjan como resultado de la voluntad asociativa de los municipios). 
Segunda.- En ese sentido, un adecuado encaje de las diputaciones provinciales en el estado autonómico es el de potenciar al máximo sus posibilidades de cooperación local con competencias funcionales sobre las materiales de los municipios. Ello sin perjuicio de ejercer todas aquellas otras competencias que las comunidades autónomas quieran atribuirles o delegarles.

Tercera.- Las diputaciones deben orientar sus políticas de cooperación hacia las demandas municipales. Los ayuntamientos deben expresar sus prioridades a la diputación, de modo que la acción concertada ponga al servicio de los municipios toda la capacidad técnica de la institución provincia

\section{EL SISTEMA DE GOBIERNO LOCAL}

Desde una perspectiva histórica, el denominado tradicionalmente régimen orgánico-funcional se ha caracterizado por ser excesivamente uniformista, con independencia de la heterogeneidad de la planta municipal. Esta situación se reproduce, asimismo, en la Ley Básica de 1985, en la que junto a un régimen común de naturaleza representativa indirecta, personalizado en la institución del ayuntamiento -que podía experimentar ligeras modulaciones en función de tramos de población-, coexiste, también con carácter básico, el régimen de Concejo Abierto en los municipios de población reducida, fórmula tradicional de democracia directa (STC 119/1995).

Este esquema tradicional de gobierno local español respondía, quizás, a un modelo excesivamente corporativo. En efecto, la distribución de funciones entre los diferentes órganos no se efectuaba de acuerdo con criterios de especialización de funciones y asunción de las respectivas responsabilidades derivadas del mandato representativo. De modo que el Pleno, junto con las grandes decisiones de índole estratégica y normativas, como el presupuesto, el planeamiento general, las ordenanzas y reglamentos, ostentaba un amplio abanico de funciones de naturaleza administrativa y ejecutiva que compartía con el Alcalde, con un claro predominio de aquél. Esta situación se ha traducido en la práctica en el hecho de que, en ocasiones, funciones de la esfera propia del Alcalde se hayan sometido a la intervención plenaria al entender equivocadamente que su paso por tal órgano producía el efecto taumatúrgico de conferir un plus de legitimidad democrática a las decisiones adoptadas en su seno -por ejemplo, en el supuesto de la concesión de licencias-.

Una importante corrección del sistema descrito se produjo con la reforma de la LRBRL llevada a cabo en 1999, al reforzar sustancialmente el ámbito competencial del Alcalde, mientras que se mejoraban y clarificaban los me- 
canismos de control en el seno del Pleno. Con esta idea de clarificación en la distribución intraorgánica de funciones y de quiebra del modelo organizativo uniforme, la Ley 57/2003 sustrajo de las funciones atribuidas al Pleno de los denominados "municipios de gran población" las competencias meramente gestoras, profundizando en la matriz parlamentaria que inspiraba el nuevo modelo orgánico-funcional.

En definitiva, la LRBRL de 1985 configuraba un modelo de organización híbrido al insertar una arquitectura democrática en un esquema organizativo de corte corporativo. Además, no hay que olvidar que las posibilidades de los municipios de innovar, adecuar y ordenar su respectiva organización, de acuerdo con sus necesidades, presupuestos y demandas sociales, se vio tempranamente cercenada por el Tribunal Constitucional. En efecto, como es notorio la STC 214/1989 al declarar inconstitucional el art. 5 LRBRL, por entender que se trataba de una norma meramente interpretativa sin contenido material alguno, difuminó la potencialidad efectiva del Reglamento Orgánico Municipal, dando como resultado que la estructura de los gobiernos locales viene predeterminada en tal grado que, no queda espacio para la manifestación adecuada de la potestad de autoorganización.

Circunstancia que no se compadece bien con el art. 6.1 CEAL cuando afirma que, "sin perjuicio de las disposiciones más generales creadas por la Ley, las En tidades Locales deben poder definir por si mismas las estructuras administrativas inter nas con las que pretendan dotarse, con objeto de adaptarlas a sus necesidades específi cas y a fin de permitir una gestión eficaz".

En este sucinto análisis del estado de la cuestión del sistema de gobierno local, debemos hacer, asimismo, una breve referencia a diferentes aspectos materiales que lo integran. Así, resulta oportuno destacar que el llamado "estatuto de los cargos electos" constituye una de las piezas esenciales del modelo representativo derivado de la cláusula constitucional de Estado Democrático y de la participación política a través de representantes contenida en el art. $23 \mathrm{CE}$. En este sentido, se manifiesta el grueso de las observaciones formuladas por diferentes entidades al primer Borrador de Libro Blanco respecto de esta materia, en las que se demanda una clarificación del citado estatuto -Ayuntamiento de Santa Ana (Cáceres), Diputación de Zaragoza, Asociación Catalana de Municipios, Federación Catalana de Municipios, etc.-

Asimismo, resulta conveniente detenernos en el papel que han venido desempeñando en estos últimos años los Grupos Políticos Municipales. La legislación básica estatal de régimen local ha ido perfilando paulatinamente su re- 
gulación a través de un proceso de formación en el que se distinguen tres etapas. La primera, que abarca desde 1985 hasta 1999, se caracteriza por la circunstancia de que no se prevé expresamente la obligatoriedad de la constitución de Grupos Políticos a efectos de la actuación corporativa de los Concejales, limitándose a señalar genéricamente el art. 20.3 LRBRL que «todos los gru pos políticos integrantes de la Corporación tendrán derecho a participar, mediante la presencia de Concejales pertenecientes a los mismos, en los órganos complementarios del ayuntamiento que tengan por función el estudio, informe o consulta de los asuntos que hayan de ser sometidos a la decisión del Pleno». La segunda etapa comprendería el periodo 1999-2003, al añadir la Ley 11/1999, de 21 de abril, un nuevo apartado, el tercero, al art. 73 LRBRL, en virtud del cual, «a efectos de su actuación cor porativa, los miembros de las Corporaciones locales se constituirán en grupos políticos, en la forma y con las obligaciones que se establezcan». De modo que es a partir de esta fecha cuándo se consagra la genérica obligación de los Concejales de constituirse en Grupos Políticos a efectos de su actuación municipal, con independencia del número de habitantes o cualquier otra circunstancia. Y, en último término, la tercera fase correspondería con el período que se inicia con la Ley 57/2003, de 16 de diciembre, que modifica el reiterado art. 73.3 LRBRL, manteniendo la obligatoriedad de la constitución de Grupos Políticos a efectos de la actuación corporativa de los Ediles, «con excepción de aquellos que no se integren en el grupo político que constituya la formación electoral por la que fue ron elegidos o que abandonen su grupo de procedencia que tendrán la consideración de miembros no adscritos».

De la sucinta exposición anterior se deduce que la regulación de los Grupos Políticos en el ámbito municipal contenida en la legislación básica estatal ha evolucionado desde el supuesto de la no obligatoriedad de su constitución - 1985-1999-, a exigirse por mandato legal dicha constitución obligatoria con carácter general -1999-2003-, si bien ésta se exceptúa en los supuestos establecidos en el propio art. 73.3 -2003-.

Teniendo en cuenta que los Grupos Políticos articulan y racionalizan la vida política de los órganos colegiados de la entidad local respectiva, a través del ejercicio de esenciales funciones complementarias, instrumentales e internas, la Comisión entiende que debe mantenerse su regulación actual limitándose, a lo sumo, a clarificar el alcance y régimen jurídico de los denominados "Concejales no adscritos", y valorando la posibilidad de eximir de la obligación de actuación grupal en los municipios de menos de 1.000 habitantes.

De otra parte, es necesario efectuar una sucinta referencia al denominado "sistema electoral local", partiendo de la idea de que, en la actualidad, no 
puede hablarse en España de una crisis del mismo, ni de una verdadera demanda social para su cambio. En general, puede sostenerse que el vigente sistema electoral español garantiza un grado suficiente de representación del pluralismo político y la gobernabilidad de las instituciones locales. Aseveración que se ve reforzada por el dictamen del Consejo de Europa, cuando afirma que no existe ningún argumento convincente para modificar el sistema actual de elección de Alcalde y Concejales, así como por el escaso interés suscitado en las diferentes observaciones formuladas al primer Borrador del Libro Blanco.

Junto a los extremos acabados de apuntar la futura Ley de Bases deberá mantener y mejorar los actuales estándares mínimos en materia participativa de la LRBRL, y en este sentido se comparte la proposición no de ley aprobada por el Congreso de los Diputados con ocasión del Debate sobre el Estado de la Nación, instando al Gobierno a prestar un Proyecto de Ley Básica del Gobierno y la Administración Local que, entre otros extremos, potencie la participación de los ciudadanos en la vida pública local.

Además de estos estándares mínimos, debe impulsarse a los gobiernos locales para que, en el ejercicio de su potestad de autoorganización, establezcan mecanismos participativos adecuados a sus circunstancias, para lo cual podrán inspirarse en la Recomendación 19 (2001) del Comité de Ministros del Consejo de Europa, sobre la participación de los ciudadanos en la vida pública local.

Un último aspecto sobre el que hay que llamar brevemente la atención es el de la función directiva en el ámbito local, compuesta exclusivamente de personas con la cualificación y experiencia adecuada y que puedan ser designadas para el desempeño de las funciones gerenciales que precisan los Gobiernos Locales. Esta concreta clase de personal, responsable de la gestión de servicios y dirección de áreas específicas, procedente tanto del sector público como del privado añade valor a la actuación y gestión municipal.

A juicio de la Comisión, la adecuación de las estructuras de gobierno local deben enmarcarse y responder a la dinámica democrática de mayorías y minorías. Así aquel partido o candidatura que gobierne como resultado de haber ganado unas elecciones debería gobernar, y aquel partido o candidatura que haya perdido debería disponer de garantías adecuadas para controlar de manera efectiva al gobierno democráticamente constituido.

El objetivo ha de ser conciliar la constitución de gobiernos fuertes y la garantía de que una minoría no quede al albur de la mayoría, en tanto que es 
garantía de la expresión del pluralismo político y, por tanto, hace imprescindible articular garantías para el desarrollo de la actuación de la oposición. Se trata de sustantivar la función de gobierno y establecer un estatuto de la oposición.

Por ello se plantea la necesidad de un nuevo modelo de gobierno local que habrá de encontrar soporte legal en una consideración del reglamento orgánico que efectivamente ensanche el ámbito de autoorganización de los ayuntamientos mientras la legislación básica asegure unas reglas de juego que impidan que las mayorías puedan limitar la capacidad para desarrollar adecuadamente la función de la oposición.

No estamos ya ante organizaciones, los ayuntamientos, que hayan de enfrentarse a necesidades evidentes, muy al contrario la realidad local obliga cada vez más a dar respuestas a nuevos problemas que exigen dotarse de organizaciones complejas que permitan la adopción y el desarrollo de las políticas necesarias. Situación que, en definitiva, pone de manifiesto la necesidad de facilitar que la diversidad y la pluralidad en el diseño de gobiernos y administraciones locales sean realmente efectivas.

\section{La estructura que se pretende debe conseguir tres objetivos esenciales:}

a) Un gobierno local eficaz y ágil, capaz de adoptar las decisiones necesarias para la gestión en el momento adecuado, y con atribuciones que comprendan todos los aspectos gestores de la entidad local.

b) Una oposición que disponga mecanismos eficaces de control y seguimiento de la gestión, que formen parte de un sistema de frenos y contrapesos al ejecutivo reforzado que se sugiere.

c) La consideración de la organización administrativa como una manifestación de la función de Gobierno, en el sentido de que, partiendo de la existencia de unas normas básicas generales, cada Entidad Local ha de poder adaptar su respectiva organización administrativa a sus necesidades reales en ejercicio de su potestad de autoorganización.

\section{PROPUESTAS}

El sistema tradicional de gobierno local que se desprende de la LRBRL de 1985, tiene difícil encaje en modelos de sociedad en constante transformación que exigen sistemas más ágiles de gobierno y con una nítida distribución de 
responsabilidades. Existe una clara necesidad de adaptación a las especificidades de cada municipio que impone la existencia de un ámbito de libertad que permita a los ayuntamientos definir, en función de las prioridades políticas de la acción de gobierno, la estructura administrativa más adecuada. De manera que, las cuestiones más relevantes sobre las que la Comisión entiende que debe hacerse mayor hincapié son las siguientes:

Primera.- Se debe destacar el papel relevante que han de desempeñar las normas orgánicas en materia de organización. Este aserto, a su vez, se traduce en diferentes aspectos como son: primero, que la legislación básica ha de establecer los principios mínimos a los que debe ajustarse la organización municipal, provincial e insular en todo el territorio, a efectos de garantizar un sistema mínimo homogéneo. Segundo, que la correcta interpretación sistemática de los arts. 6.1 CEAL y $137 \mathrm{CE}$ induce a sostener que las entidades locales, en ejercicio de su potestad de autoorganización, deben gozar de la suficiente libertad y margen de maniobra para ordenar y adecuar su organización a las necesidades reales y efectivas de cada uno de ellas.

De manera que en materia de organización municipal, tal y como ha señalado el Tribunal Constitucional, "el orden constitucional de distribución de com petencias se funda en el reconocimiento de tres ámbitos normativos correspondientes a la legislación básica del Estado (art. 149.1.18 de la Constitución), la legislación de desa rrollo de las Comunidades Autónomas según los respectivos Estatutos y la potestad re glamentaria de los municipios"

(STC 214/1989). Tercero, y último, se puede sostener que la conclusión en este punto es que, a diferencia de lo que viene sucediendo hasta la fecha, habrá de motivarse qué es aquello que se extrae de regulación en las normas orgánicas. Es decir, habrán de motivarse las materias que, en este ámbito, se consideran básicas sustrayéndose a la potestad de autoorganización. Por ello, los órganos complementarios han de quedar a la potestad de autoorganización de cada Entidad Local, comenzando por la administración. Carece de fundamento que una Ley prescriba como obligatorios determinados órganos administrativos cuya existencia puede apreciarse mejor en función de la peculiaridad de cada municipio.

Segunda.-Se hace preciso ahondar más en la reflexión sobre el denominado estatuto de los electos y las garantías de las minorías. Tal y como se ha apuntado con anterioridad, las relaciones gobierno-oposición en el ámbito municipal se han visto lastradas por una concepción en exceso corporativa, en el sentido de que la única función que correspondía a la minoría consistía en 
el control del equipo de gobierno por parte del Pleno. Desde el punto de vista de la Comisión la función de la oposición no debe consistir en un mero "control del Pleno" sino, por el contrario, ha de garantizarse el "control en el Ple no". Esta concepción de las minorías no se limita a un cambio en la preposición, sino que ha de traducirse en medidas concretas de actuación de las mismas: la regulación del acceso directo a la información municipal así como del acceso a la información sometido a autorización, solicitar la comparecencia de órganos directivos unipersonales ante el Pleno, el reconocimiento de la posibilidad de constituir Comisiones de Investigación sobre asuntos determinados, etc.

Al tiempo, y en estrecha conexión con lo anterior, se plantea la posibilidad fáctica de perfilar un estatuto de los electos locales -concejales y diputados- a través del cual, y en sus aspectos básicos, se garantice el ius in officium de los mismos, pues no hay que olvidar que, a fin de cuentas, el ejercicio del derecho a participar en los asuntos públicos a través de representantes se trata de un derecho fundamental de configuración legal. Además, lo anterior presenta la virtualidad de servir de criterio para definir lo básico en el gobierno local, en la medida en que coadyuva a garantizar a las minorías la intervención en las decisiones claves del municipio. Sería contrario a la democracia que las eventuales mayorías aprovecharan una situación coyuntural de dominio para impedir que las minorías las controlaran y se erigieran en alternativa.

En este sentido, hay que poner de relieve que una de las demandas que con mayor énfasis habían proclamado los electos locales está, en la actualidad, en vías de solución. En efecto, es sabido que la vigente normativa no concede cobertura de paro a los representantes locales en caso que no vuelvan a salir elegidos, lo que parece contrario a la finalidad perseguida por el artículo 7.2 de la CEAL, situación que se pretende corregir a través de la presentación por los grupos políticos con representación parlamentaria en fechas recientes de una proposición de Ley relativa a la extensión de la protección por desempleo a determinados cargos públicos y sindicales.

En este orden de cosas la Comisión considera oportuno recoger las peticiones formuladas por las más diversas entidades locales en el sentido de atribuir a las Audiencias Provinciales respectivas la competencia para la instrucción, conocimiento y fallo de todos los delitos y faltas cometidos por los miembros de las entidades locales en el ejercicio de sus cargos. Junto ello, la Comisión considera conveniente clarificar el significado y alcance del artículo 121 del Código Penal vigente en el sentido de que las Administraciones Públicas responden subsidiariamente de los daños causados por las autoridades, fun- 
cionarios o agentes cuando cometen delitos en el ejercicio de sus cargos, pero no cuando cometen faltas.

La Comisión cree que la adopción conjunta de las dos medidas mencionadas no supone introducir privilegio alguno en favor de los miembros de las entidades locales, puesto que es claro que las relaciones de las autoridades y funcionarios con la ciudadanía son mucho más intensas y afectan mucho más a la vida cotidiana de los ciudadanos que las relaciones que se conciertan de forma voluntaria, con empresas y particulares, en las que el riesgo de que se produzcan situaciones de conflicto es mucho menor. Por ello, parece conveniente la adopción de las medidas propuestas en aras a impedir, o al menos obstaculizar, el uso abusivo de la acción penal contra miembros de las entidades locales por motivos espurios o para obtener más fácilmente una indemnización.

Tercera.- La Comisión entiende que la organización necesaria intraorgánica debe estructurarse, en los municipios de más de 1.000 habitantes, de acuerdo con unas notas básicas como son: primera, los órganos necesarios se articularían en dos figuras: el Alcalde o Presidente y la Asamblea, que actuaría en Pleno y Comisiones. De modo que el Pleno se configuraría como el órgano deliberante que adopta las grandes decisiones estratégicas que constituyen el marco de la gestión municipal -el presupuesto, el planeamiento urbanístico, las ordenanzas, los reglamentos, etc.-, a las que se añaden otras funciones que, por su propia naturaleza, deben corresponder al mismo -aprobación de símbolos, integración en organizaciones supramunicipales, etc.-, sin que, en ningún caso, el Pleno pueda ostentar competencias de naturaleza gestora, ni siquiera por delegación de otros órganos de la Entidad, ni de otras Administraciones. Bajo esta perspectiva se ahonda más en la dimensión política de la Asamblea municipal asemejándola formalmente al esquema parlamentario.

Cuarta.- Quien ha ganado las elecciones tiene la responsabilidad del gobierno, no puede hacer dejación de las funciones inherentes al mismo y transferir a la Asamblea Municipal las atribuciones que la Ley le asigna. Por ello, el elenco de las funciones y competencias del Alcalde serán indelegables en la Asamblea Municipal.

Quinta.-Al ejecutivo local, bajo la denominación de Consejo de Gobierno, de carácter potestativo en los municipios de menos de 1.000 habitantes, le corresponde desarrollar la gestión en su integridad, dentro del marco de las decisiones estratégicas aprobadas por la Asamblea Municipal y la representatividad del Alcalde o Presidente. Serán, pues, las normas orgánicas el instrumen- 
to normativo idóneo para que la respectiva Entidad Local, de acuerdo con sus propias características, diseñe el régimen de funciones y tareas que podrán ser delegadas o desconcentradas desde el Consejo de Gobierno a los órganos administrativos de la misma.

Sexta.- En el Pleno de la Asamblea Municipal se controla la gestión del ejecutivo local a efectos de comprobar su adecuación al marco preestablecido por aquél, sin perjuicio, claro es, del control de legalidad que en su caso pueda ejercerse por los órganos y autoridades legitimados para ello. Un aspecto sobresaliente en este ámbito, y relacionado con las funciones que han de corresponder a cada uno de los órganos necesarios, consiste en que, a juicio de la Comisión, la elección del Presidente del Pleno debe adecuarse a las necesidades de organización de la respectiva Entidad Local, de modo que exista la posibilidad de que desempeñen tal puesto el Alcalde o cualquier otro Concejal.

Séptima.-En igual sentido, la propia Entidad Local debe, de acuerdo con el principio dispositivo establecido en la Ley Básica Local, disponer de la potestad de autoorganizar su Consejo de Gobierno con los denominados "Concejales no electos”, de acuerdo con sus propias necesidades y disponibilidades presupuestarias. No obstante, en el caso de Diputaciones Provinciales, por coherencia con su naturaleza, no existirán "Diputados no electos".

Octava.-Al efecto de asegurar la coherencia del sistema de gobierno, tal y como apunta el Ayuntamiento de Madrid, se ha de asegurar que la legislación sectorial cuando atribuya competencias o funciones de naturaleza gestora a los órganos de las Entidades Locales lo realice al ayuntamiento.

Novena.-En función de la experiencia histórica acumulada, la regulación y extensión del régimen del Concejo Abierto en sus términos actuales debe mantenerse, sin que existan suficientes razones jurídicas para su ampliación a un mayor número de municipios.

\section{GESTIÓN DE SERVICIOS PÚBLICOS Y BIENES}

\section{La Gestión de Los Servicios Públicos Locales.}

La Ley 57/2003 completó el panorama de las formas de gestión de servicios públicos locales, con la uniformización de las formas de gestión indirecta mediante una remisión a la legislación sobre contratación de las administraciones públicas, e introduciendo entre las formas de gestión directa la entidad 
pública empresarial, al tiempo que permitiendo la creación de sociedades mercantiles cuyo capital social pertenezca íntegramente a entes públicos dependientes de la entidad local. Con esta solución se ofrece unas opciones que pueden resultar suficientes, si bien sería conveniente introducir algunas especialidades para una mejor adaptación a las entidades locales. Precisamente por esa necesaria adaptación a los entes locales, no parece adecuada la remisión en bloque a la LOFAGE (diseñada en función de las características propias de la Administración General del Estado), y se echa en falta una concreción sobre la vigencia el arrendamiento como forma de gestión local: posiblemente su reconocimiento en la actualidad no presente gran relevancia práctica dado que sus perfiles ya resultaban difusos, pero si propiciaría la directa aplicación del título II del Libro II del TRLCAP.

Tampoco debe olvidarse la importancia que de los consorcios como forma de gestión de servicios públicos en el ámbito local, ni la gestión mediante convenios administrativos cuando no sea precisa la creación de nuevas personas jurídicas.

Resultaría interesante también acotar el ámbito objetivo sobre el que quepa la actuación de las fundaciones, pues en algunos casos parece confuso.

La Comisión considera que en materia de servicios públicos locales ha llegado la hora de sustituir la vieja distinción entre servicios de gestión directa y servicios de gestión indirecta que contiene el artículo 85 de la LRBRL, por la más apropiada de servicios prestados en régimen de gestión propia y servicios prestados en régimen de gestión contractual.

Además, la nueva Ley debería introducir en la esfera local los nuevos conceptos y técnicas, provenientes del derecho comunitario, que el ordenamiento estatal ha incorporado a los servicios públicos de competencia estatal. Las expresiones de servicio de interés general, servicio económico de interés general o servicio universal son usadas por el ordenamiento comunitario pero, también, por nuestro propio ordenamiento jurídico interno (vid. la utilización de los conceptos "servicio universal" y "servicio de interés general" en la Ley 32/2003, de 3 noviembre, General de Telecomunicaciones -arts. 2, 3, 9,

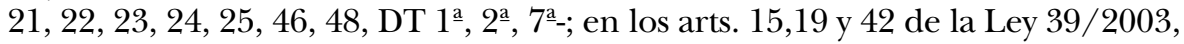
de 17 de noviembre, del Sector Ferroviario; en los arts. 6 y 15 y ss. de la Ley 24/1998, de 13 de julio, de Regulación del Servicio Postal Universal y de Liberalización de los Servicios Postales; así como en la D.A. 23 $3^{\underline{a}}$ introducida, respecto de la distribución de gas natural, por el Real Decreto-Ley 5/2005, de 11 de marzo, en la Ley 34/1998, de 7 de octubre, del Sector de Hidrocarburos). 
Recordemos que si históricamente ha existido una diferencia evidente y notable entre la concepción europea de servicio público y la americana del public utility es porque los Estados Unidos descubrieron las especialidades del servicio público a partir de una aproximación liberal -contra el Estado-, mientras que en la mayor parte de los países europeos la configuración del servicio público industrial y comercial se ha hecho configurándola como una prestación debida del Estado a sus ciudadanos.

En España, sin ir más lejos, damos por bueno que hay servicio público cuando una administración asume una prestación determinada como responsabilidad propia y se garantiza su prestación en condiciones de igualdad, continuidad y mutabilidad a todos los ciudadanos. El objeto del servicio público acostumbra a ser una prestación indispensable para satisfacer necesidades básicas de la vida personal o social, de acuerdo con las circunstancias sociales de cada momento y lugar. El servicio público es, de alguna forma, la prolongación del mercado por otros medios, cuando el mercado fracasa.

Por su parte el libro verde de la Comisión, de 21 de mayo de 2003, sobre los servicios de interés general (diario Oficial C 76, de 25.3.2004), remarca la idea de que los términos "servicio de interés general" y "servicio económico de interés general" no deben confundirse con la expresión "servicio público", un término más ambiguo que puede tener diversos significados y, por lo tanto, inducir a confusión. Interesa remarcar, además, que el término "servicios de interés general" no figura en el Tratado y que en la práctica comunitaria deriva de la expresión "servicios económicos de interés general" que sí recoge el derecho originario comunitario (art. 16 del Tratado y art. 36 de la carta de los derechos fundamentales).

Mientras que con el término servicio de interés general en la práctica comunitaria se suele designar a aquellos servicios, sometidos o no a la disciplina de mercado, que las autoridades públicas consideran de interés general y están sometidos a obligaciones específicas de servicio público, con la expresión servicio público se alude, a veces, al hecho de que un determinado servicio se ofrece al público en general, mientras que otras veces lo que se quiere resaltar es que se ha asignado a un servicio una misión específica de interés público, o se hace referencia al régimen de propiedad o al estatuto de la entidad que presta el servicio en cuestión. Por ello, se dice en el libro verde, la expresión servicio público no es utilizada en el mismo.

La distinción entre servicios de naturaleza económica y servicios de naturaleza no económica es importante a efectos comunitarios, ya que unos y otros 
no se rigen por las mismas normas del Tratado. Así, como indica el libro verde mencionado (parágrafo 43), la libertad de prestación de servicios, el derecho de establecimiento y las normas en materia de competencia y ayudas estatales del Tratado sólo se aplican a las actividades económicas.

Por último, el concepto de servicio universal, según el libro verde mencionado, designa un conjunto de requisitos de interés general que garantizan que ciertos servicios se ponen a disposición, con una calidad especificada, de todos los consumidores y usuarios en todo el territorio de un estado miembro con independencia de su situación geográfica y, en función de las circunstancias nacionales específicas, a un precio asequible. En un entorno de mercado liberalizado, una obligación de servicio universal garantiza que todos los ciudadanos tienen acceso al servicio a un precio asequible, y se mantiene -y en su caso, se mejora- su calidad.

En estas circunstancias, y atendiendo que a juicio de la Comisión la definición, supervisión y ejecución de los requisitos en materia de calidad de los servicios por parte de las autoridades públicas constituyen el elemento clave de la regulación de los servicios públicos y de los servicios de interés general, parece oportuno replantear en la nueva Ley del gobierno y la administración local la introducción de las nuevas concepciones de servicios de interés general procedentes del derecho comunitario.

La regulación contenida en la normativa catalana sobre ordenación sectorial y autorizaciones reglamentadas puede servir de inspiración para la nueva regulación, en el bien entendido de que mediante la reglamentación de las actividades se deben poder ejercer buena parte de las actividades de prestación típicamente locales (educación infantil, gimnasios y campos de deportes, escuelas de música, residencias de la tercera edad, abastecimiento de aguas, etc.).

\section{PROPUESTAS}

Primera.-Sustituir la vieja distinción entre servicios de gestión directa y servicios de gestión indirecta que contiene el artículo 85 de la LRBRL, por la más apropiada de servicios prestados en régimen de gestión propia y servicios prestados en régimen de gestión contractual, así como sustituir la remisión en bloque a la LOFAGE por especialidades más adaptadas a las entidades locales.

Segunda.-Introducir en el ordenamiento jurídico local las nociones de servicio de interés general y servicio universal procedentes del derecho comunitario, adaptándolos a las especificidades locales. Los servicios de interés ge- 
neral, entendidos en su acepción comunitaria como aquellos servicios que las autoridades públicas consideran de interés general y están sometidos a obligaciones específicas de servicio público, puede ser una categoría conceptual unitaria que se subdivida a su vez en dos subcategorías, a saber: a) servicio público, noción a que reserva a cuando la entidad local asume una prestación determinada como responsabilidad propia y se garantiza su prestación, por la propia entidad local o mediante contrato con un tercero, en condiciones de igualdad, continuidad y mutabilidad de todos los ciudadanos; b) actividad reglamentada de interés general, noción que quedaría reservada a aquellos supuestos en que el servicio es prestado por los particulares previa autorización reglamentada de la entidad local.

Lógicamente, en el nuevo marco legal los actuales servicios mínimos de carácter obligatorio deben quedar configurados como servicios locales universales, garantizando a los ciudadanos que podrán acceder a los mismos en condiciones de igualdad, continuidad, calidad y precios asequibles, con independencia de que la prestación se realice por la Administración o los particulares.

\section{Los Bienes de las Entidades Locales}

Con relación al régimen jurídico básico de los bienes de las Entidades Locales, no parece que sea precisa una importante revisión. La Comisión considera que no existen en la actualidad cuestiones que generen graves conflictos: la distinción entre bienes demaniales y patrimoniales, así como el régimen jurídico de cada uno de ellos (incluidos los comunales) es una cuestión poco o nada controvertida en nuestro sistema jurídico.

A nuestro entender, las reflexiones que sobre esta materia debemos hacer con motivo de la redacción del Libro Blanco sobre la reforma del Gobierno Local, deberían girar en torno a la necesidad de propiciar una optimización del patrimonio público local, integrado tanto por bienes de naturaleza demanial como patrimonial. Parece común en la actualidad la consideración de que debe primarse la puesta en valor de las propiedades públicas, y las Entidades Locales no deben estar fuera de esa órbita; es preciso adoptar un enfoque más dinámico del patrimonio local (esta es, además, la línea que pretendió adoptar la Ley 33/2003, de 3 de noviembre, del Patrimonio de las Administraciones Públicas). El principal objetivo debe ser, pues, la racionalización y la rentabilización en la gestión de las propiedades públicas, puesto que ello no es ni más ni menos que un aspecto de la eficiencia que debe demandarse a las Administraciones Públicas. 
Puede decirse que tradicionalmente el patrimonio público ha sido contemplado por la normativa desde un enfoque estático, desde el cual se aspiraba a la administración y defensa del mismo. En el contexto socioeconómico de nuestros días debemos reclamar una actitud más activa hacia las propiedades públicas, por ser parte del capital cuya gestión encomienda la ciudadanía a los poderes públicos. La gestión del patrimonio debe aspirar a obtener el mayor rendimiento posible del mismo. Ese mayor rendimiento podrá ser entendido como económico en unos casos, y en otros, se corresponderá con un mayor rendimiento social (puesto que los bienes demaniales no son susceptibles de la misma explotación económica que los patrimoniales).

En línea con lo anterior, sería aconsejable la adopción para el ámbito local de instrumentos similares a los previstos en el Título VI LPAP: "Coordinación y optimización de la utilización de los edificios administrativos", y que bajo esa clara rúbrica establece una serie de interesantes medidas que sintonizan con la línea de gestión patrimonial que estamos proponiendo (especialmente cabe destacar la elaboración de planes globales de las necesidades de edificios administrativos y coordinación con la disponibilidad de los que son de propiedad de la propia Administración).

La práctica demuestra que es esencial el contar con un inventario plenamente actualizado y valorado que permita el control y la defensa de todos y cada uno de los bienes que lo integran. Ello no es siempre suficientemente observado en todas las Entidades Locales de modo que la falta de inventario o la debilidad del mismo ocasionan a la Administración no pocos perjuicios económicos y entorpecimientos en la gestión de muchas actuaciones locales. Por ello, tal vez convendría reforzar la institución, con la seguridad de que ello redundará en una mejor gestión y aprovechamiento de los recursos públicos. La falta de capacidad propia de algunas Entidades Locales para la confección de sus inventarios debe ser suplida por las Entidades Locales intermedias, ordinariamente por las Diputaciones Provinciales, por ser un aspecto en el que claramente se observa la falta de capacidad económica y técnica de algunos municipios para ejercer una obligación legal, que aunque a veces no se observe como perentoria en el municipio, ocasiona numerosos contratiempos, como hemos apuntado. Ello conecta directamente con la funcionalidad de estas Entidades intermedias que deben configurarse como suplentes de la falta de recursos de algunas entidades, y con la línea de apoyo técnico que la propia LRBRL recogió tradicionalmente en su art. 36.1.b) y recientemente en su art. 70 bis.

Partiendo de las mismas consideraciones que venimos expresando, el patrimonio de las Entidades Locales debe ser considerado como uno de sus prin- 
cipales valores, y en la medida de lo posible, ha de ser una fuente de ingresos para la Entidad. Consideramos interesante reflexionar acerca de las cesiones patrimoniales porque la normativa en vigor no acota la duración de las mismas, y posiblemente ello da lugar a que las Corporaciones no puedan disponer en ocasiones de sus propios bienes por haber sido cedidos por Corporaciones anteriores. En la actualidad, con la limitación de recursos de casi cualquier Entidad local, su patrimonio debe ser rentabilizado al máximo, con lo cual, sin perjuicio del respeto a la voluntad de las Corporaciones, tal vez deban establecerse límites a que algunas operaciones patrimoniales priven de libertad de movimientos a gobiernos futuros.

Durante el período de debate sobre el borrador de este Libro Blanco, la mayoría de las aportaciones valoran positivamente las líneas propuestas ${ }^{1}$.

Sin perjuicio de que lo más interesante debe ser avanzar en las líneas que hemos expuesto, podemos concretar una serie de propuestas que sintonizan con tales ideas.

\section{PROPUESTAS}

Primera.-Asegurar un correcto engarce entre la normativa básica estatal sobre bienes y la Ley 33/2003, de 3 de noviembre, del Patrimonio de las Administraciones Públicas, adoptando las medidas que se consideren de interés de dicha ley que no resultan de aplicación al ámbito local.

Segunda.-Estudiar la posibilidad de reforzar la obligación legal de elaboración y continua actualización del inventario de bienes de las Entidades Locales, como punto de partida para una correcta estrategia de gestión patrimonial. También debe potenciarse la necesidad de consolidar los inventarios con las propiedades del "sector público local", puesto que a la postre los bienes de sociedades, organismos u otras entidades públicas deben considerarse parte del patrimonio público local con independencia de la forma que la Entidad Local haya elegido para la mejor gestión de los servicios públicos de su

\footnotetext{
${ }^{1}$ Así lo hace el Ayuntamiento de Madrid y el Colegio de Secretarios, Interventores y Tesoreros de Administración Local. La Federación Catalana de Municipios y Provincias, además de considerar que la ley básica de régimen local no debe contener normas sobre bienes, propone la supresión de los actos de tutela autonómicos sobre las operaciones patrimoniales; en todo caso, considera que podrían exigirse mayorías reforzadas para aprobar dichas operaciones.
} 
competencia (sería interesante también limitar la enajenación de patrimonio local efectuada mediante entidades instrumentales).

Tercera.- Estudiar la conveniencia de limitar aquellas figuras que permiten la cesión de patrimonio local durante prolongados periodos de tiempo, de manera que pueden comprometerse gravemente las posibilidades de gobiernos locales futuros.

\section{LAS RELACIONES INTERGUBERNAMENTALES}

UN AMPLIO DESARROLLO DE LOS PRINCIPIOS DE COOPERACIÓN Y COOR DINACIÓN INTERGUBERNAMENTALES

En un Estado compuesto como el español, las relaciones intergubernamentales deben estar presididas por la cooperación y la coordinación entre todos los actores, en un marco de respeto mutuo de sus respectivas competencias. Curiosamente, el ámbito local, a excepción de la Comisión Nacional de Administración Local -de naturaleza bilateral entre el Estado y las entidades locales- no ha constituido hasta ahora un terreno propicio para las relaciones intergubernamentales formalizadas a través de órganos de máximo nivel.

Por una parte, se ha echado de menos la existencia de un foro tripartito entre el Estado, las comunidades autónomas y las entidades locales, que posiblemente constituye el único marco posible para abordar algunos de los temas y de los problemas más importantes de la administración local en España.

Por otra parte, el diseño de las conferencias sectoriales se ha efectuado de manera que las entidades locales están presentes solamente como meras invitadas en aquellas que por razón de su materia inciden en sus competencias.

Por ello hay que saludar la constitución de la Conferencia Sectorial para Asuntos Locales (CSAL) como un hito fundamental en la consolidación de un modelo de cooperación tripartita entre el Estado, las comunidades autónomas y las entidades locales, que permitirá a través de sus grupos de trabajo y de estudio el análisis de los grandes ámbitos temáticos que comprende el gobierno local en España y la propuesta de las soluciones pertinentes a los problemas planteados, sobre la base de la negociación y del consenso interinstitucional.

La consolidación de una Comisión de segundo nivel como órgano de preparación de los acuerdos de la CSAL y de desarrollo de los mismos, con parti- 
cipación de representantes del Estado y de las Comunidades Autónomas con rango de Director General, así como de representantes de las entidades locales designados por la FEMP, constituye otro elementos esencial para la consolidación de las relaciones entre el Estado y las comunidades autónomas en este ámbito, estableciendo un cauce de relación intenso y operativo para el buen desarrollo de las funciones de la CSAL.

\section{PROPUESTAS}

- Debe consolidarse la CSAL y su órgano de apoyo de segundo nivel, cuya existencia debe reflejarse en la Ley Básica estatal. No obstante, la CSAL debería cambiar su denominación para reflejar mejor sus funciones, pues no es una Conferencia Sectorial tradicional, limitada a un ámbito materia concreto, sino que constituye un órgano de cooperación al máximo nivel que aborda la temática propia de todo un nivel de poder territorial. Por ello, su denominación debería ser la de Conferencia sobre Política Local o similar.

- También es importante la constitución de la Conferencia de Ciudades en el seno de la Conferencia sobre Política Local. En ella, junto a los representantes del Estado y de las comunidades autónomas, se encontrarán los alcalde de todos las grandes ciudades, constituyendo el marco idóneo para abordar las políticas que específicamente afectan a nuestras áreas urbanas y metropolitanas.

- De la misma manera, hay que abogar para que las entidades locales españolas, a través de la asociación de ámbito estatal más representativa, estén presentes como miembros de pleno derecho en las conferencias sectoriales y órganos asimilados que afecten a sus competencias. De especial importancia es su presencia en el Consejo de Política Fiscal y Financiera, por la relevancia de este órgano en el diseño del modelo tributario en un marco de federalismo fiscal y de corresponsabilidad.

- Habría que plantearse también el papel futuro de la Comisión Nacional de Administración Local en un marco hipotético de consolidación de la CSAL y de presencia institucionalizada de las entidades locales en las conferencias sectoriales que les afecten.

- Sería importante reforzar la función de estudio, análisis y seguimiento de los gobiernos locales en España, tanto a través de la Dirección General de Cooperación Local como mediante un centro u organismo especializado en 
el que participasen el Estado y las entidades locales, que podría denominarse "Instituto de Gobierno Local", (a semejanza del extinto Instituto de Estudios de Administración Local).

- En el caso de la Dirección General de Cooperación Local, además, debe ser la sede de bancos de datos elaborados en colaboración con las otras administraciones públicas que permitan un conocimiento correcto de la situación de la administración local en España en todos los aspectos relevantes: cargos electivos, recursos humanos, estructuras territoriales y entes personificados, calidad de vida, etc. Unas bases de datos que -salvo las que contengan datos de carácter personal- deben estar al servicio de todas las administraciones y de los ciudadanos, y constituir elementos para una mejor formulación de las políticas públicas que afecten a los gobiernos locales españoles.

- El uso intensivo de la figura de los convenios interadministrativos entre dos y tres niveles de poder territorial parece constituir una pieza esencial en el sistema de relaciones intergubernamentales, sin tener que recurrir necesariamente a una inflación organizativa que muchas veces no resulta pertinente.

- Los municipios y las demás entidades locales deben tener el derecho a participar en los procesos de planificación y programación de las infraestructuras, equipamientos y servicios que, siendo de la titularidad del Estado y de las comunidades autónomas, les afecten de manera directa. En tales procesos deberán ser respetados en todo caso los intereses locales, en la medida en que no sean incompatibles ni menoscaben los intereses supramunicipales afectados.

- Todas las administraciones públicas deberán ser oídas preceptivamente cuando una de ellas pretenda desafectar un bien demanial afecto a un uso o servicio público, de forma que si otra de ellas tuviese que ejecutar una infraestructura, servicio o equipamiento que satisfaga una necesidad de la población, goce de preferencia para la adjudicación del terreno desafectado, siempre que éste reúna las características adecuadas para ello y sea compatible con las previsiones del planeamiento municipal.

- Por los que se refiere a las relaciones de conflicto, un acceso más fácil de las entidades locales al Tribunal Constitucional, rebajando sensiblemente y de forma razonable los quorums requeridos para la interposición de los conflictos en defensa de la autonomía local, reforzaría notablemente la posición relativa de los gobiernos locales en el sistema de relaciones intergubernamenta- 
les y, posiblemente, produciría de forma colateral efectos preventivos disuasorios a la hora de regular en materias que afectan a la autonomía local.

\section{VIII.LA COOPERACIÓN LOCAL EN EL ÁMBITO INTERNACIONAL}

Las entidades locales, y especialmente los municipios, desarrollan una creciente actividad internacional y transnacional, especialmente en el ámbito europeo y, dentro de este continente, en las zonas fronterizas, siendo también cada vez más importante e intensa la cooperación internacional para el desarrollo.

Además de la actividad de cooperación en ámbitos prestacionales y/o asistenciales, es también importante la actividad asociativa de las entidades locales en el ámbito internacional (europeo y mundial), para la promoción y defensa de sus intereses comunes, tanto con fines generales como sectoriales. Esta actividad de cooperación y de asociación en la esfera internacional encuentra su cobertura normativa en el artículo 10.2 y 10.3 de la Carta Europea de la Autonomía Local.

La regulación de esa actividad internacional es muy dispar: existe un marco amplio en el caso de la cooperación transfronteriza entre entidades territoriales, regulada por el Convenio-Marco Europeo de Madrid, desarrollado por tratados bilaterales de cooperación transfronteriza entre España y Francia (Convenio de Bayona) y entre España y Portugal (Convenio de Valencia).

Asimismo existe una regulación suficiente en el caso de la cooperación internacional para el desarrollo, contenida tanto en la ley estatal sobre la materia como en numerosas leyes autonómicas.

Hay que destacar, por otra parte, el importante impulso que para la cooperación para el desarrollo supone la transformación del Ministerio de Asuntos Exteriores en Ministerio de Asuntos Exteriores y de Cooperación, con la creación de la Secretaría de Estado de Cooperación Internacional y el fortalecimiento de la Comisión Interterritorial de Cooperación para el Desarrollo, que con toda seguridad contribuirá a mejorar la necesaria coordinación de la acción exterior de nuestras entidades territoriales, necesaria para, sin perjuicio de su autonomía, lograr más información sobre su acción en esta materia y la potenciación de las sinergias necesarias para optimizar el uso de los recursos españoles en este nuevo ámbito de política pública. 
No obstante, fuera de estos supuestos, se carece de una regulación básica de las condiciones generales de la cooperación internacional de los municipios, siempre en el marco del respeto a su autonomía en la materia.

\section{PROPUESTAS}

- Debe incorporarse a la Ley básica estatal el contenido del artículo 10.2 y 10.3 de la Carta Europea de la Autonomía Local, que consagran el derecho de asociación y de cooperación de las entidades locales en el ámbito internacional.

- Es preciso fijar de manera expresa las condiciones básicas condiciones básicas de la acción internacional de las entidades locales, que son las siguientes:

a) El pleno respeto a la política exterior del Estado.

b) La actuación dentro del ámbito competencial de la entidad territorial de que se trate.

c) La adecuación del gasto y de su justificación a la normativa española en materia de haciendas locales.

d) La comunicación de toda actividad internacional al Ministerio de Administraciones Públicas y al Ministerio de Asuntos Exteriores y Cooperación.

- El marco normativo de la cooperación transfronteriza de las entidades locales españolas debe completarse con la firma y ratificación de los protocolos adicionales 1 y 2 del Convenio-Marco de Madrid, materia en la que los países fronterizos con España llevan ventaja, pues Portugal a firmado ambos y Francia ha ratificado el primero y firmado el segundo.

Dicho completamiento también exige el desarrollo mediante convenio de la cooperación transfronteriza entre entidades territoriales con el Principado de Andorra.

- También es preciso que la legislación básica estatal amplíe los mecanismos personificados que pueden utilizarse por las entidades locales españolas en la cooperación transfronteriza. Actualmente, la única fórmula autorizada en el caso de encontrase la sede en España, de acuerdo con los Tratado de Bayona y de Valencia, es la del consorcio (transfronterizo). A esta figura debe añadirse al menos la posibilidad de crear sociedades mercantiles de titularidad 
intermunicipal y estudiar la posibilidad de mancomunidades transfronterizas de municipios ${ }^{1}$.

\section{ANEXO I}

\section{MIEMBROS INTEGRANTES DE LA COMISIÓN}

\section{Presidente:}

-José Luis Méndez Romeu. Secretario de Estado de Cooperación Territorial del Ministerio de Administraciones Públicas.

-Ana Isabel Leyva Díez. Secretaria de Estado de Cooperación Territorial del Ministerio de Administraciones Públicas.

Director:

-Manuel Zafra Víctor. Director General de Cooperación Local del Ministerio de Administraciones Públicas

Secretario:

- José Manuel Rodríguez Álvarez. Subdirector General de Relaciones Institucionales y Cooperación Local del Ministerio de Administraciones Públicas.

Vocales:

-Gabriel Álvarez Fernández. Secretario del Ayuntamiento de Santa Marta de Tormes (Salamanca).

-Pilar Atienza Gabás. Subdirectora General Adjunta de Relaciones Institucionales del Ministerio de Administraciones Públicas

-Ana Belén Cruz Valiño. Directora del Gabinete del Secretario de Estado de Cooperación Territorial del Ministerio de Administraciones Públicas.

-Gonzalo Brun Brun. Director Técnico Jurídico de la Federación Española de Municipios y Provincias.

-José Miguel Carbonero Gallardo. Subdirector General de Régimen Jurídico y Bases de Datos Locales del Ministerio de Administraciones Públicas.

-Joan Echaniz Sanz. Fundación Democracia y Gobierno Local

-Myriam Fernández-Coronado González. Directora de Coordinación de Políticas Locales de la Federación Española de Municipios y Provincias.

-Joaquín Ferret Jacas. Catedrático de Derecho Administrativo de la Universidad Autónoma de Barcelona.

-Antonio Pedro Fogué Moya. Fundación Democracia y Gobierno Local.

\footnotetext{
${ }^{1}$ En este sentido se ha manifestado la Mancomunidad de Municipios de Txingudi (Irún y Hondarribia).
} 
-Ana María García Fernández. Jefe de Área de la Función Pública Local del Ministerio de Administraciones Públicas.

-José Ignacio Martínez de Aragón Calvo. Director de Política Territorial de la Federación Española de Municipios y Provincias.

-Manuel Medina Guerrero. Director de la Fundación Democracia y Gobierno Local.

-Luciano Parejo Alonso. Catedrático de Derecho Administrativo de la Universidad Carlos III de Madrid.

-Miguel Ángel Pérez Grande. Director del Gabinete de la Secretaría de Estado de Cooperación Territorial del Ministerio de Administraciones Públicas.

-Manuel Julio Sánchez Senn. Asesor del Secretario de Estado de Cooperación Territorial del Ministerio de Administraciones Públicas.

-Ferran Torres Cobas. Director de los Servicios Jurídicos de la Diputación de Barcelona.

-Julio Alberto Torres Pérez. Secretario General de la Federación Española de Municipios y Provincias.

\section{ANEXO II}

ENTIDADES Y ORGANIZACIONES QUE HAN FORMULADO PROPUESTAS AL TEXTO DEL LIBRO BLANCO

\section{AYUNTAMIENTOS :}

-Acehúche (Cáceres)

-Aldeanueva de la Vera (Cáceres)

- Almonacid del Marquesado (Cuenca)

-Ansó y de Fago (Huesca)

- Becerreá (Lugo)

- Binissalem (Mallorca)

- Bustarviejo (Madrid)

- Calatayud (Zaragoza)

-Calvíá (Mallorca)

- Campos (Islas Baleares)

- Castrillo de Onielo (Palencia)

- Cebrones del Río (León)

-Cercedilla (Madrid)

-Felanitx (Islas Baleares)

- Las Palmas de Gran Canaria 
- Lobon (Badajoz)

- Madrid

- Malacuera (Guadalajara)

- Mantinos (Palencia)

- Manzanares (C. Real)

-Martorell (Barcelona)

-Montornés del Vallés (Barcelona)

-Ossa de Montiel (Albacete)

-Palma de Río (Córdoba)

-Pamplona

-Petra (Mallorca)

- Portezuelo (Cáceres)

- Prats de Lluçanés (Barcelona)

-Sant Boi De Llobregat (Barcelona)

-Sant Joan De Labritja (Islas Baleares)

- Sant Pere Sallavinera (Barcelona)

-Santa Ana (Cáceres)

-Santa María D’oló (Barcelona)

-Sevilla

-Sollana (Valencia)

- Talavera de la Reina (Toledo)

-Tomares (Sevilla)

- Torrelodones (Madrid)

- Valencia

-Zamora Castilla La Mancha

DIPUTACIONES Y CONSEJOS INSULARES:

- Diputación Foral de Vizcaya

- Castellón

- Málaga

- Orense

- Zaragoza

- D' Eivissa

- Formentera

\section{MANCOMUNIDADES:}

- Mancomunidad Costa Sol Occidental

-Mancomunidad de Servicios de Txingudi

\section{MINISTERIOS:}

-Defensa 


\section{COMUNIDADES AUTÓNOMAS:}

- Gobierno de Aragón

- Junta de Comunidades de Castilla La Mancha

-Junta de Comunidades de Castilla y León

- Generalitat de Cataluña

- Junta de Andalucía

-Gobierno del Principado de Asturias

\section{FEDERACIONES Y ASOCIACIONES DE MUNICIPIOS :}

-Federación Española de Municipios y Provincias

- Federación Aragonesa de Municipios, Comarcas y Provincias.

-Federación de Municipios de Cantabria

-Federación de Municipios de Catalunya

-Asociación Catalana de Municipios y Comarcas

\section{PARROQUIAS RURALES :}

- Agones (Pravia) Asturias

- Ballota (Cudillero) Asturias

- Bances (Pravia) Asturias

- Busmente (Asturias)

- Caleao (Caso) Asturias

- Cerredo (Asturias)

- Escoredo (Pravia) Asturias

- Faedo (Cudillero) Asturias

-Fresnedo (Teverga) Asturias

-Muyamayor y Beiciella (Cudillero)

-Asturias

-Loro (Pravia) Asturias

-Los Cabos (Pravia) Asturias

-Pandenes (Cabranes) Asturias

-Saliencia (Somiedo) Asturias

-San Cosme (Cudillero)Asturias

-San Juan de Piñera (Cudillero)

-Asturias Sandamias (Pravia) Asturias

-Santa María De Llas (Cabrales) Asturias

-Santianes Del Rey Silo (Pravia) Asturias

-Sobrefoz (Ponga) Asturias Varcia y Taja (Teverga) Asturias

-Varcia y Leijan (Valdes) Asturias Villamayor (Piloña) Asturias

\section{OTRAS APORTACIONES:}

-Fundación Democracia y Gobierno Local

-Colegios de Secretarios, Interventores y Tesoreros de Administración Local 
Asociación Nacional de Inspectores de la Hacienda Pública Local Asociación "Valencia Metropolitana"

Izquierda Unida Xuventudes Socialistas de Galicia

Francisco J. Arenas Cabello

Javier Bustamante Moreno

$M^{\underline{a}}$ del Carmen Fernández

Santiago Gasset

Álvaro Gimeno

José María Gisbert Querol

José Antonio Gómez

Isaac Ibáñez García

José Luis López Cebolla

Ignacio Mir Fullera

Jesús Perandones

Javier Rodríguez

Juan Manuel Ruiz Galdón

Ginés Valera Escobar

Enega. 